\title{
QK926 G44
}

(1)

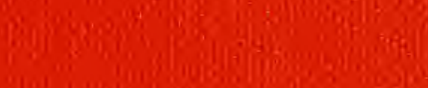

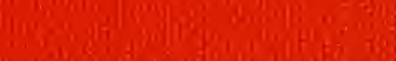

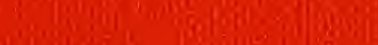
\% re: f: Thing 7.

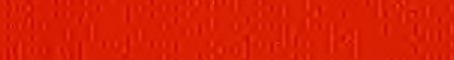
i y. 10.129

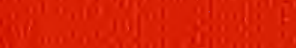
Ang (a)

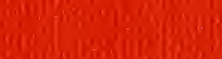
minges d. 


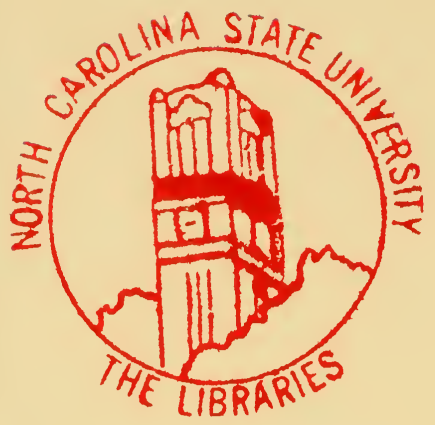

NORTH CAROLINA STATE UNIVERSITY LIBRARIES

- 
This book is due on the date indicated below and is subject to an overdue fine as posted at the circulation desk.

\section{EXCEPTION: Date due will be earlier if this item is RECALLED.}

JUN 302004 

GIBSON NATURE STUDIES 




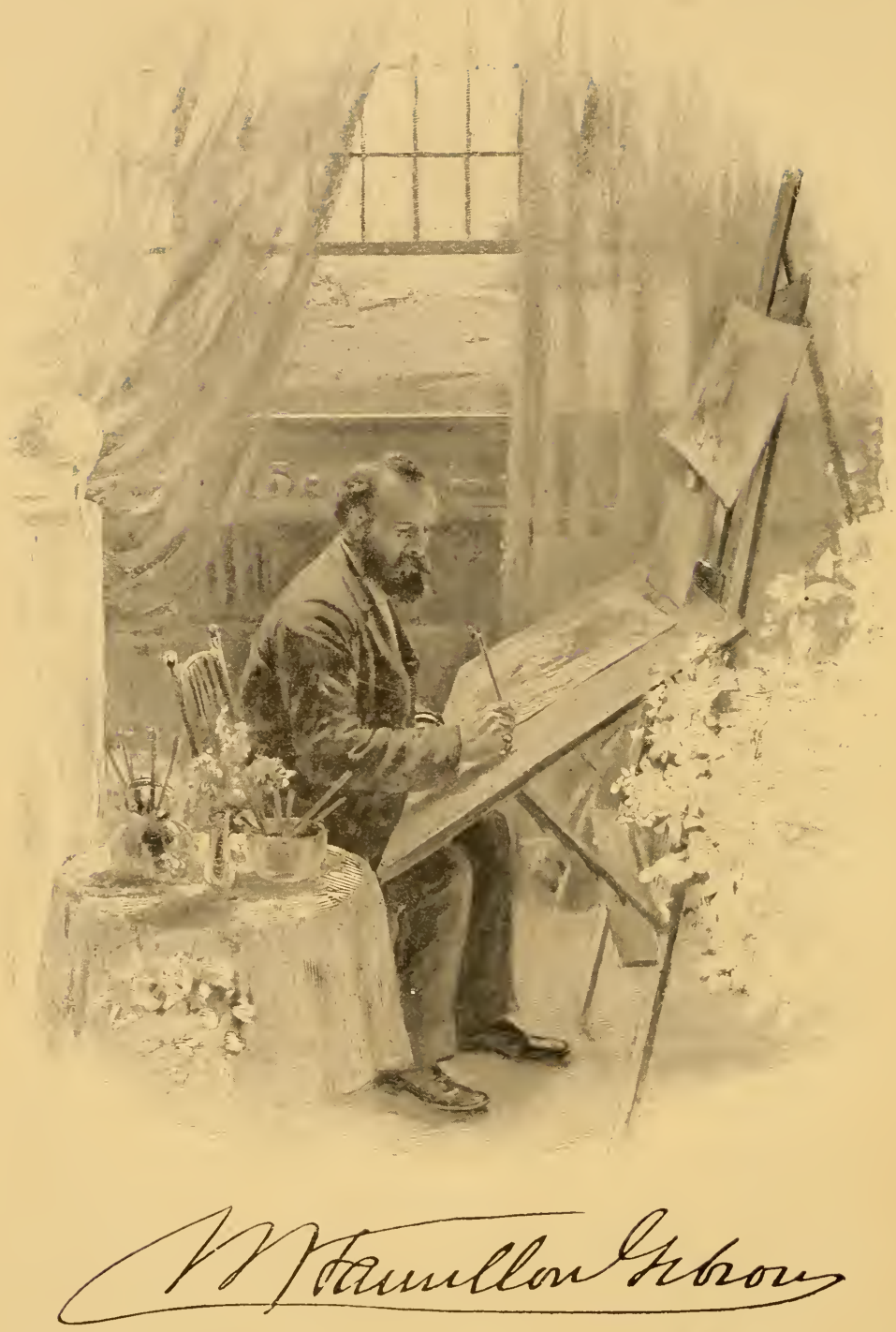




\section{BLOSSOM HOSTS AND INSECT GUESTS}

HOW THE HEATH FAMLY. THE BLUETS, THE FIGWORTS, THE ORCHIDS AND SIMILAR WILD FLOWERS WELCOME THE BEE THE FLY, THE WASP, THE MOTH AND OTHER FAITHFUL INSECTS

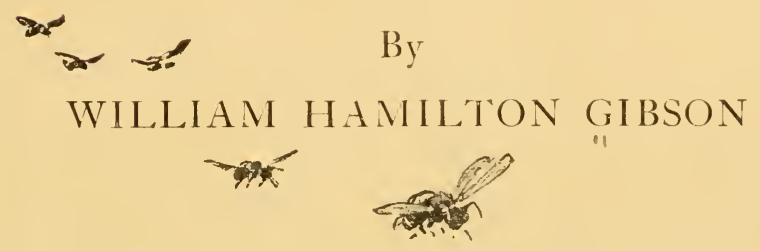

Edited by ELEANOR E. DAV'IE ILLUSTRATED BY THE AUTHOR

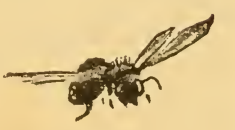

NEWSON\& COMPANY NEW YORK. 


\section{PUBLISHERS' NOTE}

WV are indebted to the courtesy of Messrs. Harper \& Brothers, the publishers of Mr. William Hamilton Gibson's books, for permission to compile this volume from the work of that distinguished author and artist.

1020

Copyright, 1880,1882, 1886, 1890,1891, 1897, by Harper \& Brothers.

Copyright, 1901, by Newson \& Company. 


\section{PREFACE}

"Blosson Hosts and Insect Guests" is an exposition of the method by which flowers are fertilized, a subject which Mr. Gibson was the first American to investigate, his patient study resulting in many valuable contributions to scientific knowledge in this direction.

"No one knew more of flowers, shrubs, trees and insects or of the special haunts and homes of all of them, and even readers to whom botany is a sealed book may follow him into the fields and woods and marshes with a full certainty of being charmed and enlightened in unexpected ways. He was his own teacher in what was best, and those who have the task of training amateur naturalists should see well to it that they catch, if they can, the secret of his success."

He not only ranked high as a scientist, but undoubtedly stood at the head of the artist-writers of our country, "his graceful, poetical prose being nearly of equal value with his fine and delicate drawings. His style is full of glowing freshness. His vii

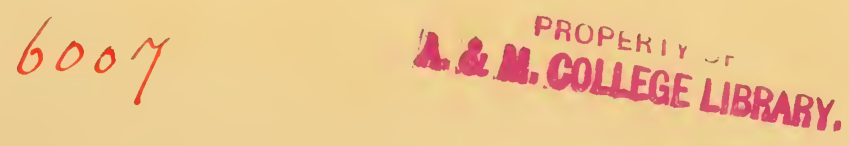


mind springs beyond the hackneyed and commonplace. His genius is of the imaginative order."

The results of his researches, embodied in magazine articles, ${ }^{*}$ excited marked attention and did much to stimulate inquiry into flower fertilization among other scientists, as well as to interest the general public by their novelty, charm and beauty. In that shape, however, they have never been fully appreciated, and we are merely following out the author's own intentions in bringing this scattered material together in permanent form.

No effort has been spared to make the book thoroughly comprehensive and in every way representative of the author's work in this branch of science, which was so peculiarly his own, everything of value, both in the way of information and illustration, that he ever contributed to the subject. being embodied in the present volume. Care has been taken, too, to preserve the charm of his literary style, no alterations having been made in the text that were not rendered absolutely necessary in endeavoring to make a logical, harmonious whole of scattered articles. A little new matter has been added to certain chapters where the different members of a family showed such marked individuality

* Afterward reprinted in the same form. 


\section{Preface}

that fuller treatment than that originally accorded seemed desirable.

The plan of the book is as follows: First, the history of the discovery of the method of flower fertilization is carefully traced, then the method is worked out and explained in the case of an abstract flower, and the modifications of the various flower organs, due to their adaptation to their insect visitors, by means of natural selection, pointed out. The remainder of the book consists of twenty-five concrete examples of different methods of crossfertilization. These examples stand as types of the ordinary processes adopted by nature.

It is thought that no method of preventing self. fertilization and insuring the opposite result exists among our wild flora that has not its prototype in these pages. As Gibson himself says of the orchids : "Each new species affords its new surprise in its special modification in adaptation to its insect sponsors;" but the general method is based on one of the plans illustrated.

In addition to furnishing a complete exposition of the processes involved, the book will be found a guide to the habits and characteristics of many individual species, tables being appended giving all the data at present available for about two 
hundred and sixty flowers. The matter tabulated gives such important points as family, common and botanical names, insect visitors, and where the flowers are highly developed, the method of prerenting or limiting self-fertilization.

It is suggested that the book be treated after the manner now employed by the best teachers in dealing with the English classics; that is, that it shall be used primarily as a reader and that the composition work shall then be drawn from it. The objection heretofore to treating scientific books in this way has been their lack of literary merit, which made them too poor a basis for the study of English, which necessarily goes hand in hand with composition work. This objection removed, as it has been in the present case, the method is ideal. The teacher's edition of "Blossom Hosts and Insect Guests" renders such a course possible for the busiest teacher, providing composition outlines and all other necessary aids for doing satisfactory work with the least possible expenditure of time and labor.

Ruskin says: "The more I think of it, I find this conclusion more impressed upon me, that the greatest thing a human soul ever does in this world is to see something. . . Hundreds of people can talk 


\section{Preface}

for one who can think, but thousands can think for one who can see. To see clearly is poetry, prophecy and religion-all in one." No study that could be named offers such a reward to keen observation as this subject of the fertilization of flowers, for so little of the vast scientific territory that it covers has been explored that it is quite possible for any ordinarily faithful student to add something to the world's knowledge of the laws that govern it.

E. E. D. 


•




\section{TABLE OF CONTENTS}

PAGE

The Discoreries of Four Great Botanists; being the history of the discovery of the process of cross-fertilization.

Iow the Flowers Woo the Insects; wherein is discussed the degree to which adaptation to an insect may be carried, and the laws governing it.

'The Barberry Family: 'The Barberry's Welcome to Master Bombus.

'The Pulse Family: The Honeyed Clover-The Beggar's Tick.

The Evening Primrose Family: 'The Evening Primrose and the Hovering Moth.

The Noonday Lesson of the Primrose.

'The Madder Family: 'The Riddle of the Bluets Guessed by botlı Bees and Butterflies

The Composita Family: Composita Manners and now they Charm the Insects.

The Heath Family: 'The Mountain Laurel's Embrace.

Andromeda's Thim.

The Figwort Family: The Homely Figwort Attractive to Mistress IVasp.

The Wood-Betony, a Protégé of the Bumblebee.

The Mint Family: Sage Tea for the Bees-Horse-Balm Honey. 9I

The Milkweed Family.-The Milkweed: a Bluebeard Blossom. 97

Bluebeard's Methods.

The Arum Family: 'The Lords and Ladies of the Arum Family.

'The Iris Family: The Swaying Iris.

The Lily Family: The Blazing-Star and Other Lilies.

The Canada Lily and its Cousins ('The Fire Lily and the

Bermuda Lily)_The Dog-Tooth Tiolet.

The Orchid Family: Orchid Blossoms and how they differ from other flowers.

The Showy Orchid. 


\section{Table of Contents}

The Purple-Fringed and the Ragged Orchid.

PAGE

The Great Green Orchis and the Rattlesnake-Plantain.

I 35

Arethusa and Pogonia.

If I

The Moccasin-Flower.

I 5 I

157

Nature's Inexhaustible Treasures.

Supplement.

Index. 


\section{IIST OF ILLUSTRATIONS}

\section{Full-page Illustrations}

William Hanilton Gibson.

A Honey-Dew Picnic.

Frontispiece

In Archin' Bowers ('The Barberry).

The Evening Primrose.

How Bluets are Fertilized.

Method of Pollination in the Figwort.

The Milkweed as Bluebeard.

The Showy Orchid.

The Rattlesnake-Plantain.

The Arethusa.

The Moccasin-Flower.

\section{Text Illustrations}

Nature's Garden.

Cleistogamous Buds of the Violet.

Autumn Sharpshooters.

Tail-piece (Vase of Flowers).

Head-piece (Butterflies about a Plant).

A Woodland Path.

Companions.

Tail-piece (Drinking the Health of the Jolly Apis).

Head-piece (Barberry Blossoms).

Tail-piece (Bees).

Head-piece (Clover).

The Beggar's Tick.

Stick-Seed Plants of the Autumn Woods.

Tail-piece (Landscape).

Head-piece (Primroses).

Moths which Feed upon the Primrose Buds issuing from their 
Varying Buds of the Primrose.

Tail-piece (enlarged Primrose Moth).

Head-piece (Noonday Primroses).

Tail-piece (Moth Visitor of the Primrose).

Tail-piece (Butterfly).

Head-piece (Brown-Eyed Susan).

Tail-piece (Seed Tufts of the Groundsel Tree).

Head-piece (Mountain Laurel).

Tail-piece (Harebell).

Head-piece (Andromeda).

Tail-piece (Landscape).

Head-piece (Figwort).

Tail-piece (Conventionalized Figwort).

Head-piece (Wood-Betony).

Tail-piece (Foxglove).

Head-piece (Landscape).

Collinsonia, or Horse-Balm.

Tail-piece (Bee).

Head-piece (Milkweed).

Tail-piece (Milkweed Down).

Head-piece (Milkweed Pods).

Tail-piece (Dogbane and its Tictim).

Head-piece (the Calla).

Swamp-Cabbage.

Tail-piece (Landscape).

Head-piece (Iris).

Tail-piece (Iris Leaves).

Head-piece (Blazing-Star and Arethusa Blossoms)。

Fire Lilies.

Tail-piece (Solomon's-Seal).

Head-piece (Orchid Blossoms).

Tail-piece (Orchid).

Head-piece (Orchids).

Tail-piece (Landscape).

Head-piece (Ragged Orchid).

Tail-piece (Butterfly).

Head-piece (Great Green Orchis).

Tail-piece (Landscape).

Head-piece (Orchids).

Tail-piece (Landscape). 
Head-piece (White Cypripedium).

Tail-piece (Landscape).

Head-piece (Flowers Welcoming Butterfly). $\quad 167$

Tail-piece (Dicentra).

Figures showing principally the Structure and Wethod of Pollination of the arious Flowers

An abstract Flower.

Figures showing historical progression in the discoveries relating to Flower fertilization.

Figure illustrating Grew's idea of how Flowers were fertilized. 5

Figure showing condition where self-fertilization is impossible. 7

Figure showing mechanical method of preventing self-fertilization.

Figure showing conditions necessitating insect intervention. $\quad$ I3

Stamens.

Varying Flower organs.

Figures illustrating method of fertilization in the Barberry. 40, $4 \mathrm{I}$

Varying Buds of the Primrose.

Figure showing the "worm i" the bud" in the Primrose. 52

Figures showing two forms of Flowers produced by the Bluets. 6I

Cross-section of Brown-Eyed Susan. 68

Figures showing Compositæ method of fertilization. 69

Figure showing disposition of Stamens in the Laurel. $\quad 72$

Figure showing action of Stamens during visit of a Bee. $\quad 73$

Figures illustrating structure of Andromeda. $\quad 77$

Figures showing methods of Wasp in visiting Figwort. $\quad 82,83$

Seed-Pod of the Figwort.

Figures showing structure and process of fertilization of the Sage.

Figures showing structure and method of fertilization of the Horse-Balm.

Figures illustrating structure of the Milkweed. IOI

Figures illustrating structure of the Arum. IIO

Figures illustrating method of fertilization of the Arum. II I

Figures illustrating method of fertilization of the Iris. I. 7

Figures illustrating structure of the Blazing-Star. $\quad$ I20

Figures illustrating structure of an Orchid. $\quad$ I26

$\begin{array}{ll}\text { Figures showing columns of the Orchids. } & 127\end{array}$

An Orchid Seed-Pod. $\quad \mathbb{1 2 8}$ 
Figures showing the structure of the Showy Orchid.

Figures showing drooping tendency of Pollinia of the Showy

Orchid.

Figures showing the method of Pollination of the Showy

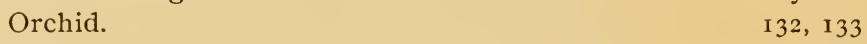

Orchid.

Figure showing the structure of the Purple-Fringed Orchid. $\quad 136$

$\begin{array}{ll}\text { Figure showing the structure of the Ragged Orchid. } & \text { I37 }\end{array}$

Figure illustrating structure of the Ragged Orchid (side view). I 38

Figures illustrating method of fertilization of the Ragged

Orchid.

Figures illustrating structure of the Tubercled Orchid. Ito

Figure showing the structure of the Great Green Orchis. $\quad I+2$

Figures showing method of its fertilization.

Figures showing the structure of the Rattlesnake-Plantain. $\quad$ I45

Figures showing disposition of the pollen in the Rattlesnake-

Plantain.

Figures illustrating method of pollination in the Rattlesnake-

Plantain.

Figure showing tongue of a Bee extended and folded beneath the head.

Figures showing method of fertilization of the Arethusa.

Figure giving profile view of the Pogonia.

Figures illustrating method of pollination of the Pogonia.

Figure showing structure of the Pink Moccasin-Flower.

Cross-sections of the Moccasin-Flower showing Bee within. I60, I6I Cross-section of Moccasin-Flower showing Bee in contact with

Stigma.

Figure showing Bee raising Anther Lid of the Moccasin-Flower. I65 
LET us then content ourselves no longer with neing mere "botanists" - historians of structural facts. The flowers are not mere comely or curious vegetable creations, with colors, odors, petals, stamens, and innumerable technical attributes. The wonted insight alike of scientist, philosopher, theologian, and dreamer is now repudiated in the new revelation. Beauty is not "its own excuse for being," nor was fragrance ever " wasted on the desert air." The seer has at last heard and interpreted the voice in the wilderness. The flower is no longer a simple passive victim in the busy bee's sweet pillage, but rather a conscious being, with hopes, aspirations, and companionships. The insect is its counterpart. Its fragrance is but a perfumed whisper of welcome, its color is as the wooing blush and rosy lip, its portals are decked for his coming, and its sweet hospitalities humored to his tarrying, and as it finally speeds its parting affinity, it rests content that its life's consummation has been fulfilled.

William Hamitom Gibson. 



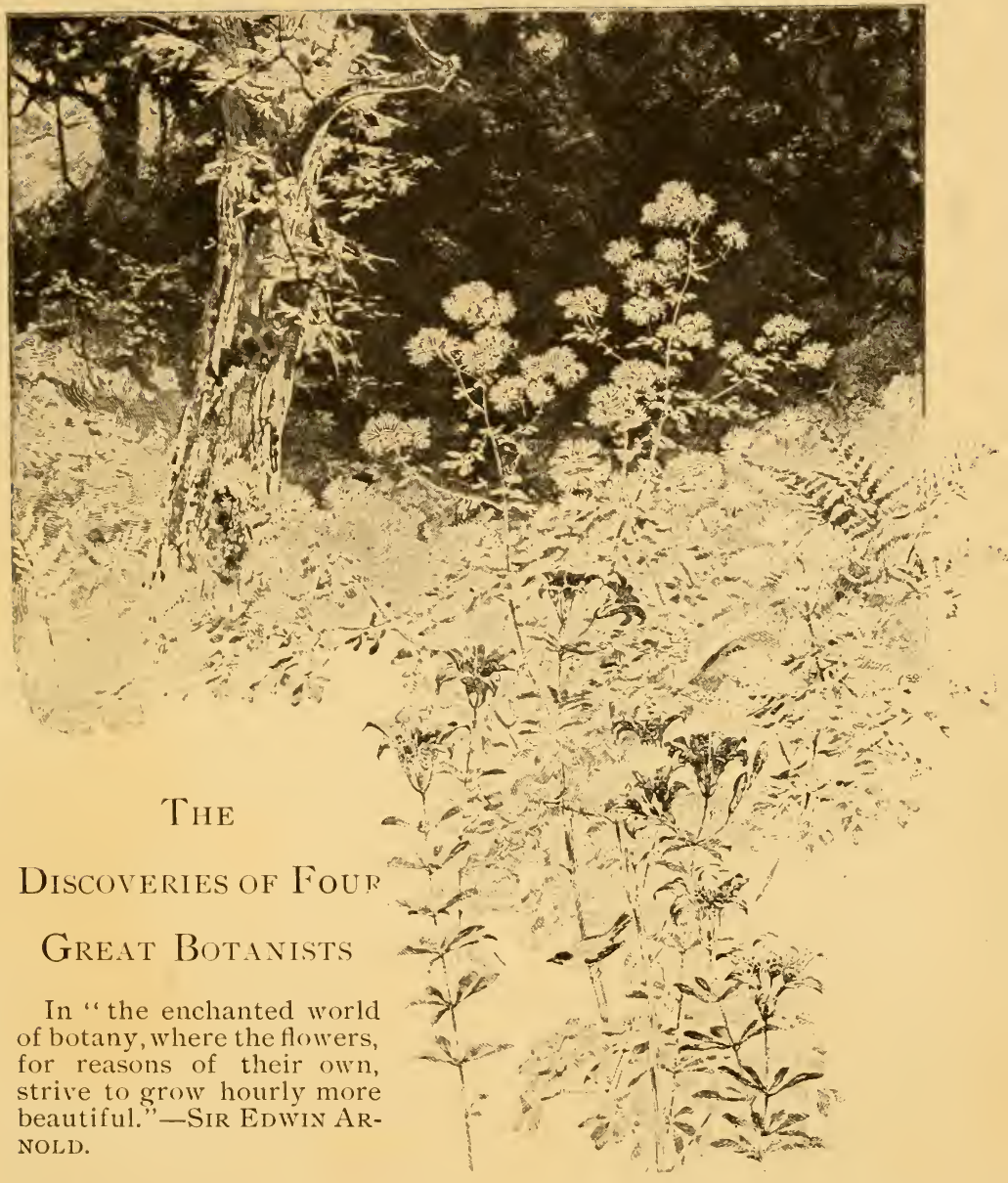

WONderful as are the revelations of the "old botany" regarding the exquisite structure of the flowers, they are as nothing compared with the marvels which the "new botany" has to reveal. 


\section{Blossom Hosts and Insect Gllests}

The "old botany" concerned itself with the flowers only after they were dead-that is, plucked from the stalk - and then, having analyzed or separated them into their parts, asked no further questions about them. The "new botany," on the contrary, concerns itself with the flowers as indi. viduals, studies them in their haunts, and inquires into their habits of life and the purpose of their existence.

A parallel to these two methods of study is found in the ornithological field-the early ornithologists contenting themselves with shooting and dissecting their bird, and the later investigators studying it while on the wing or occupied with nesting duties.

The superiority, both in interest and value, of the knowledge of the living flower or the living bird over that of the dead specimen need not be demonstrated.

In order to appreciate fully the contrast between these widely dissimilar schools of inquiry, it is well to trace briefly the progress, step by step, from the consideration of the mere anatomical and physiological specimen of the seventeenth century botanist to the conscious blossom of to-day with its embodied hopes, aspirations, and welcome companionship.

Most of my readers are familiar with the general 


\section{The Discoveries of Four Great Botanists}

construction of a flower, but in order to insure such comprehension, it is well, perhaps, to freshen our memory by reference to the accompanying diagram, Fig. I, of an abstract flower, the various parts being indexed.

The calyx usually encloses the bud, and may be tubular or composed of

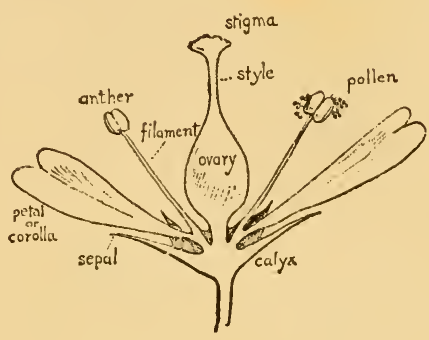

FIG. r. separate leaves or sepals, as in a rose. The corolla, or colored portion, may consist of several petals, as in the rose, or of a single one, as in the morningglory. At the centre is the pistil, or pistils, which form the ultimate fruit. The pistil is divided into three parts-ovary, style, and stigma. Surrounding the pistil are the stamens, few or many, the anther at the extremity containing the powdery pollen.

The botanists of a thousand years ago could have readily named these parts, but regarding their relation to each other, they could have told you nothing. GREIV EXPLAINS THE RELATION OF STAMENS AND PISTILS

The first observer to give to the world any information on this subject was Nehemias Grew, who announced in 1682 that it was necessary for the 


\section{Blossom Hosts and Insect Gulests}

pollen of a flower to reach the stigma or summit of the pistil in order to insure the fruit.

I have indicated his claim pictorially at $\mathrm{A}$, Fig. 2, in the series of historical progression. So
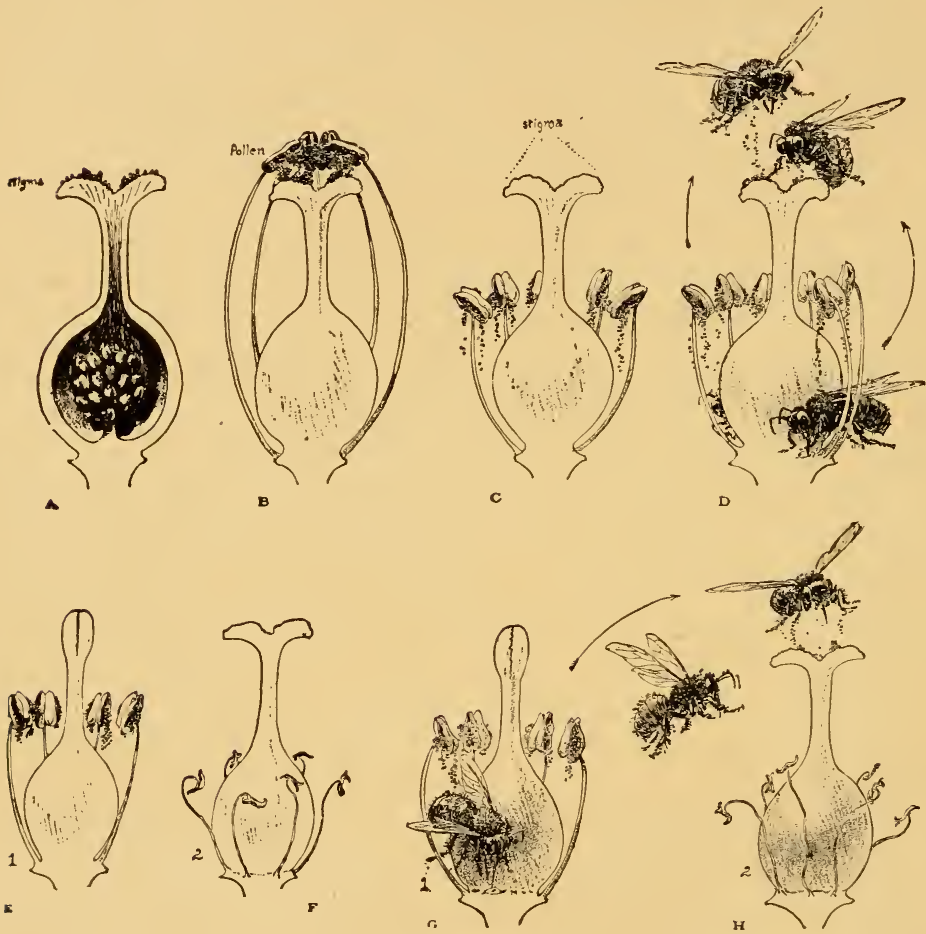

FIG. 2 .

radical was this "theory" considered that it precipitated a lively discussion among the wiseheads, which was prolonged for fifty years, and was only finally 


\section{The Discoveries of Four Great Botanists}

settled by Linnaeus, who reaffirmed the facts declared by Grew, and verified them by such absolute proof that no further doubts could be entertained. The inference of these early authorities regarding this process of fertilization or pollination of the stigma is perfectly clear from their statements. The stamens in most flowers were seen to surround the pistil, "and, of course, the presumption was that they naturally shed the pollen upon the stigma," as illustrated at B, Fig. 2 and in Fig. 3. The construction of most flowers certainly seems designed to fulfil, and frequently does fulfil, this end, but Nature does her best to prevent such an occurrence, favoring a very different process.

This theory might account, then, for the functions of the stamens and pistil; but what relation did color, fragrance, honey, and insect association bear to this problem of seed production? Had they anything to do with it, and if they had, what part did they play?

SOME EARLY SPECULATIONS

Some of the early speculations regarding these phe-

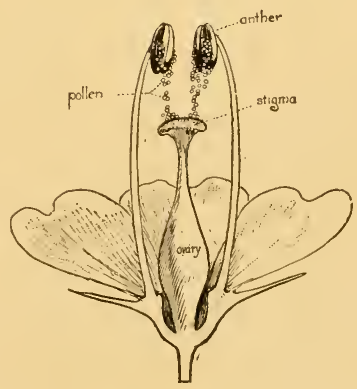

FIG. 3 . nomena were very curious. Patrick Blair, for 


\section{Blossom Hosts and Insect Guests}

instance, claimed that "honey," or, more properly, nectar, "absorbed the pollen," and thus fertilized the ovary. Pontidera thought that its office was to keep the ovary in a moist condition. Another botanist argued that it was "useless material thrown off in process of growth." Krunitz noted that "beevisited meadows were most healthy," and his inference was that "honey was injurious to the flowers, and that bees were useful in carrying it off "! The great Linnæus confessed himself puzzled as to its function.

SPRENGEL MAKES KNOWN OTHER FLORAL SECRETS

For a period of fifty years the progress of interpretation was completely arrested. The flowers remained without a champion until i 787 , when Sprengel began his investigations.

He labored on the work of interpretation for two or three years, and at length his researches were given to the world. In a volume bearing the victorious title, "The Secrets of Nature in Forms and Fertilization Discovered," he presented a vast chronicle of astonishing facts. The previous discoveries of Grew and Linnæus were right so far as they went --viz., the pollen must reach the stigma in order that the flower might produce seed, but those learned authorities had missed the true secret of the process. 


\section{The Discoveries of Four Creat Botanists}

Sprengel pointed out that in many flowers the stamens were far below the stigma, as shown in C, Fig. 2 and in Fig. 4. How, then, could the pollen reach the stigma? Clearly not in the manner suggested by Grew and Linnæus.

Sprengel partially solved this mystery. He cast a ray of light into the darkness, but it was

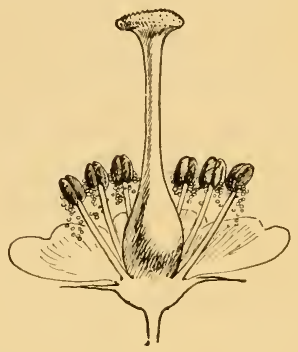

FIG. 4 . not strong enough to reveal the whole truth.

He announced the startling theory that:

I. Flowers, which, from their structure, are unable to fertilize themselves, are fertilized by insects.

II. That all such flowers contain nectar, which is food for insects, and that, in obtaining this food, the insects brush the pollen from the anthers with the hairy parts of their bodies. As they fly away, they necessarily come in contact with the stigma, which scrapes off the pollen they have just collected and is thus fertilized. D, Fig. 2, represents the process suggested.

This theory, he claimed, would explain also the presence of color and fragrance *-both of these attributes serving to attract insects, the color also

* No sooner was this fact asserted than it was urged that certain flowers, which Sprengel afterward called "Shein saft blumen," or sham-nectar producers, of which the Orchis morio is a good 


\section{Blossom Hosts and Insect Cuests}

pointing the way to the nectar*-the spots, rings, and converging lines on the petals constituting so many guide-posts on the road to the nectary.

THE WEAK POINTS IN SPRENGEL'S THEORY

Why was Sprengel's seeming victory an empty one? All that he stated about nectar, fragrance, and color is true. These floral attributes are the result of adaptation to insects, and have been acquired for the special purpose of attracting them. His theory fitted perfectly, too, the problem shown in C, Fig. 2 and in Fig. 4. An insect could without doubt fertilize such a flower with its own pollen, but Sprengel's carefully noted facts showed only too plainly that there were many other flowers incapable of fertilizing themselves, and yet quite as incapable of being fertilized in the way he had described.

For instance, he was met at every hand by floral problems, such as are shown at E and F, Fig. 2,

example, possessed perfect nectar guides, and yet produced no nectar. Sprengel supposed that these plants existed by an organized system of deception, by leading the insects to suppose that nectar was concealed in their depths, and thus inducing them to enter and perform the service of the transfer of pollen, and then cheating them of their reward. Darwin, however, showed that the nectar in Orchis morio was contained in the upper and lower tissues of the corolla; he also explained the reason for this concealment. (See page 27.) Many flowers produce quantities of pollen and little or no nectar. Such flowers are especially adapted to pollen-gathering insects.

* Evil-smelling flowers, like the trillium, attract carrion-loving flies - the vile odor of these blossoms being the result of adaptation to this special class of insects. 


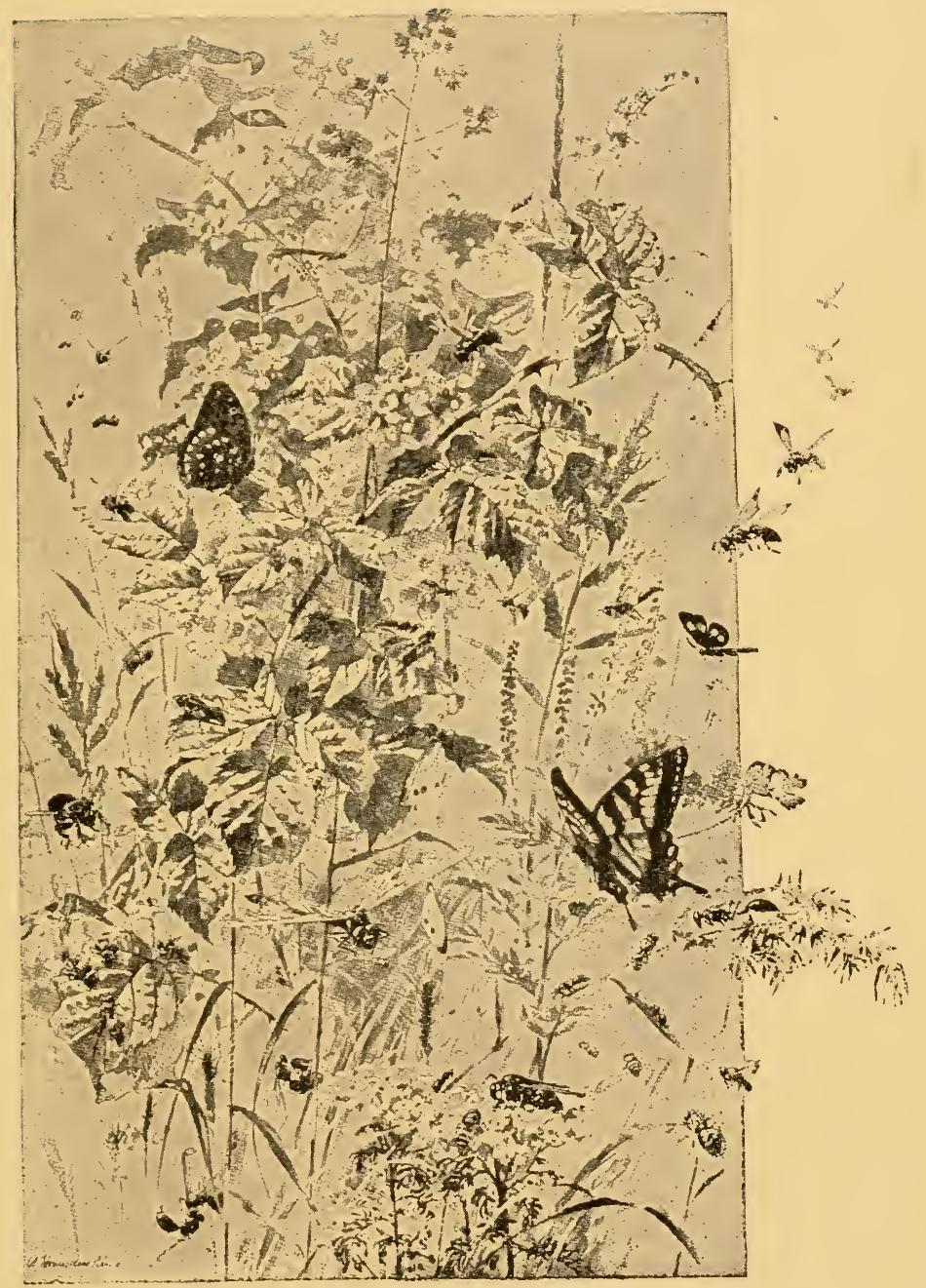

A HONEY-DEW PICNIC 


\section{Blossom Hosts and Insect Guests}

where the pollen ripens before the stigma matures. In many cases, too, the pollen-bearing stamens are all

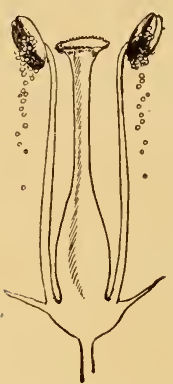

FIG. 5 . in one flower, while the pistils are in others, as in the cucumber and Indian corn, and in some instances, as in the palms and willows, on different plants. A purely mechanical method of preventing self-fertilization is shown in Fig. 5. These phenomena are, however, all of one class. When the method of fertilization in one case is understood, it may be applied to all.

Under the conditions presented at $\mathrm{E}$ and $\mathrm{F}$, if the insect did deposit the flower's pollen on its own stigma, the pollen would fail in its mission, since the stigma would not yet have reached the point where it could make use of the gift. The reverse problem also faced him, the pollen often being retained within the anthers until the stigma withers. In spite of these facts, he saw that this class of flowers continued to exist and to produce seed, but their method of doing it steadily eluded him.

In addition to this weakness in Sprengel*s theory, there was yet another defect. Sprengel could give no reason why insect fertilization was more desirable than self-fertilization. Why should the flowers be 


\section{The Discoveries of Four Great Botanists}

at such pains to attract the insects when by a different arrangement of their internal economy they might, as other blossoms frequently do, fertilize themselves?

"Let us not underrate the value of a fact; it will one day flower in a truth." The defects in Sprengel's work were, after all, not actual defects. The error lay simply in his interpretation of the facts which he had been at such pains to gather.

He and his followers heard faint whisperings of the truth which would have solved all difficulties. But they heard whisperings only-they never realized the whole of the deep-laid plan.

DARITIS'S REIELATIONS

It was not until the inspired insight of Darwin, as voiced in his "Origin of Species," contemplated these strange facts and inconsistencies of Sprengel that their full significance and actual value were discovered and demonstrated, and his remarkable book, forgotten for seventy years, at last appreciated for its true worth. Alas for the irony of fate! Under Darwin's interpretation, the very "defects" which had rendered Sprengel's work a failure became the absolute witness of a deeper truth which Sprengel had failed to discern.

One more short step and he would have reached 


\section{Blossom Hosts and Insect Gulests}

the goal. But this last step was reserved for the later seer.

Darwin took the double problem of Sprengel, as shown at E and F, Fig. 2, and by the simple drawing of a line, as it were, as in $\mathrm{G}$ and $\mathrm{H}$, instantly reconciled all the previous perplexities and inconsistencies, thus demonstrating the fundamental plan involved in floral construction to be not merely "insect fertilization" of the individual flower, the fatal postulate assumed by Sprengel, but "cross-fertilization" by insects," the carrying of the pollen from flower to flower, either of the same plant or of different plants-a fact which, singularly enough, Sprengel's own pages proved, but which he only dimly suspected. Fig. 6 shows the same condition as represented by $\mathrm{G}$ and $\mathrm{H}$, Fig. 2.

While the stigma of $\mathrm{G}$ is immature and cannot avail itself of the pollen in its own flower, the stigma of $\mathrm{H}$ is fully developed, while its pollen-bearing anthers have withered.

An insect--let us say Bombus-however, can readily remedy this difficulty. Crawling into the nectary of G, he gets himself well powdered with its pollen, which he forthwith carries to the stigma of

* Insects are by no means the only agents which nature employs in this work of pollen transfer-birds, wind, and water also assist in the work; but it is with insects as the chief agents that this book is concerned. 


\section{The Discoveries of Four Grat Botanists}

$\mathrm{H}$, and thus fertilizes it. Doubtless he will do the same for the stigma of $\mathrm{G}$ when it matures.

Not only did Darwin's theory solve the first mystery which Sprengel left unexplained, but it was equally successful in untangling the second knot.

No reason could be given why fertilization by insects, according to the theory of Sprengel, was
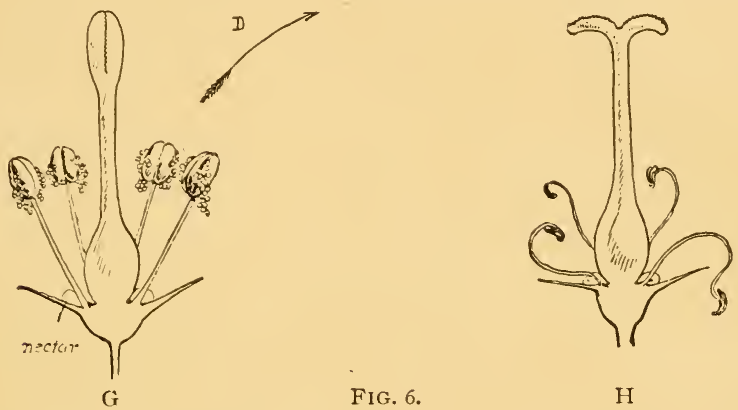

FIG. 6.

$\mathrm{H}$

preferable to self-fertilization; but, as Darwin soon proved by actual experiment, cross-fertilization is a distinct advantage to the flower, in the competitive struggle for existence, all cross-fertilized flowers producing healt hier seed than self-fertilized ones. Crossfertilized flowers, therefore, are the final result of natural selection, or the law of the survival of the fittest.

HOW MATURAL SELECTION PERFECTS THE FLOUERS

To illustrate how this law has worked in the development of cross-fertilized flowers, let us suppose, 
what has, without doubt, actually been the case, that the early ancestors of a certain flower were self-fertilized. At length, among other continual variations, ${ }^{*}$ certain seedlings showed the singular variation of ripening their pollen in advance of their stigmas or in other ways developed peculiarities which prevented self-fertilization. At the same time that they began to develop this condition, the flowers began to secrete nectar in their cups. A passing insect, lured by the sweets, entered a blossom, and while sipping its honey dew became dusted with its pollen, which he deposited on the stigma of the next flower he visited. $\nmid$

The flower thus fertilized acquired a strain of fresh vigor. Its seedlings coming now into competition with the existing weaker self-fertilized forms, by the increased vigor won in the struggle of their immediate surroundings, and inheriting the peculiarity of their parents, showed flowers possessing the same cross-fertilizing device. The seeds from these again scattering continued the unequal struggle in a larger and larger field, and in increasing

* It is this tendency to variation in individual flowers that makes it possible for nature to select and preserve traits and peculiarities which are of value to the plant.

† The fulfilment of these conditions implies, of course, flowers in various stages of development-some with ripe anthers and immature stigmas, and some with mature stigmas and withered anthers. 


\section{The Discoveries of Four Griat Botanists}

numbers, continually crowding out all their less vigorous self-fertilized competitors of the same species, at length to become entire masters of the field and the only representatives left to perpetuate the line of descent.

Everything in nature is in a state of change or evolution, and we can find flowers of all degrees in the scale of cross-fertilization, from those at a low stage of development, adapted to insects as a whole, but not to any special class, and often retaining, as a last resort, the power of self-fertilization, to those which, like the orchid, can be fertilized only by a single species of insect, and actually perish if it fails to visit them.

The question here arises, are there any flowers that are invariably self-fertilized? There are a few.

CLEISTOGAMOUS BUDS

A good example of such a flower is found in the violet, which produces two distinct blossoms on the same plant, one a little blind or "cleistogamous" flower, which grows close to the ground and which is always self-fertilized, and the other the showy blossom, with which we are all familiar, this latter blossom being formed for cross-fertilization.

The blind flower is rarely seen, as it is a tiny 


\section{Blossom Hosts and Insect Guests}

pointed affair, which never even peeps beyond its calyx. Unpretentious as it seems, it produces a pod that is literally packed with seeds. It matures in the late summer and autumn.

These seed packets are among the finest sharp-

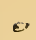

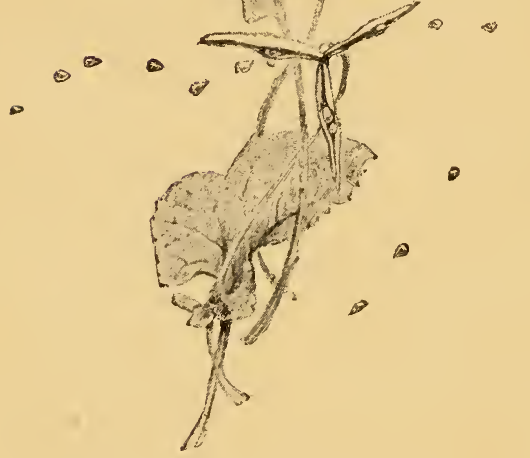

THE VIOLET'S BLIND FLOWER shooters of the autumn woods, often pinching out their pear-shaped seeds a distance of ten feet upon the dried leaves.

Cleistogamous flowèrs are an economical provision, as they produce many seeds at small cost to the plant. They doubtless prove of great value, too, where there are few insects or where other conditions exist unfarorable to frequent cross-fertilization.

The ginseng, the polygala, and some other plants hide their cleistogamous flowers below ground. The fact that these self-fertilized flowers are always found on plants bearing also cross-fertilized blossoms goes to prove that Nature never leaves a 


\section{The Discoveries of Four Great Botanists}

flowering plant * wholly dependent for the propagation of its kind upon seeds produced by the selffertilized method, providing, if need be, two varying

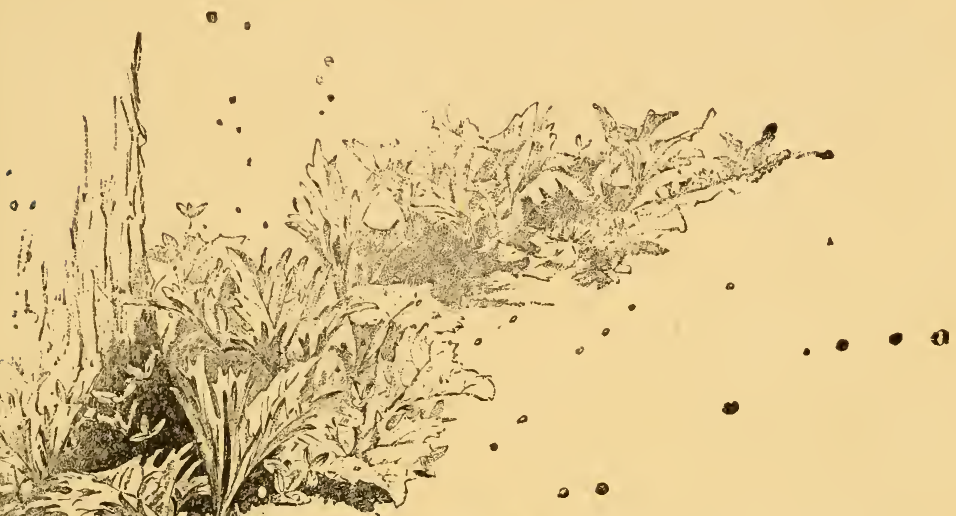

- ALTUMN SHARP-SHOOTER

blossoms on the same plant in order to insure the production of some seed by the cross-fertilized process.

*'These terms, flowering and non-flowering plants, used throughout this explanation are not strictly correct, but answer all practical purposes. In this volume we are dealing exclusively with flowering plants which form only one part of the vegetable kingdom. Any explanation regarding seeds or spores produced by asexual union in ferns, mosses, etc., would lead us into the realm of non-flowering plants-another great division of the plant world. 


\section{Blossom Hosts and Insect Guests}

Darwin states it as his belief that none of the higher forms of plant life (flowering plants) can fertilize itself for a number of successive generations. It must be crossed with another individual occasionally, preferably one on a different plant, and the more frequently this crossing of races occurs the better it is for the plant.

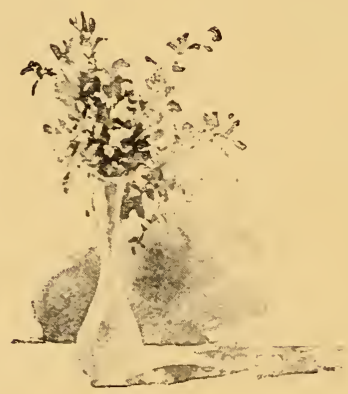




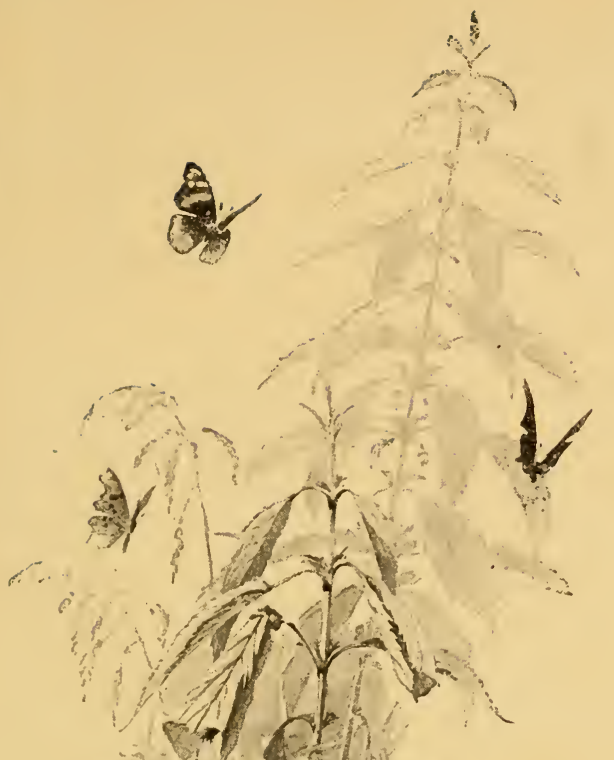

HOW THE FLOWERS Woo the Insects

"Gold-barred butterflies, to and fro,

And over the waterside wandered and wove, As heedless and idle as clouds that rove

And drift by the peaks of perpetual snow."

IDLE indeed! Observe the insect more carefully, my poet! We have cherished the thought of the "idle butterfly," the type of charming heedlessness, too long. He is no idler, but a hard worker and an earnest student, who could tell the wisest of us, if he would speak, more true science than we have ever dreamed of.

It was the constant presence of these "idlers" at the blossoms' throats that led Sorengel and Darwin 


\section{Blossom Hosts and Insect Gulests}

to that close study of the flowers which resulted in our present knowledge of the method by which they perpetuate themselves. 'This is a wonderful scientific truth; but the butterfly whispers that there is more to learn, that there always will be more to learn.

The flower of to-day! What an inspiration to our reverential study! What a new revelation is borne upon its perfume! Its forms and hues, what invitations to our devotion! This spot upon the petal; this peculiar quality of perfume or odor; this fringe within the throat $;$ this stamen and pistil, so close that they almost touch, and yet so widely separated! IVhat a catechism to one who knows that each and all represent an affinity to some insect -a long-tongued night moth, perhaps, with whose life its own is mysteriously linked through the sweet bond of perfume and nectar and the sole hope of posterity.

Having found, as it were, our marvellous crossfertilized flowers, let us enter any woodland path and, plucking a few blossoms, examine them more closely, for we have by no means fathomed all the mysteries of their adaptation to insects, or even guessed to what extent it may be carried, or the

* The fringe protects the nectar from rain. 


\section{How the Flowers Woo the Insects}

reasons that underlie the varying structure of the different organs.

NECTARY RIDDLES

Here, for instance, are two flowers-one with a long and narrow nectary, and the other with a

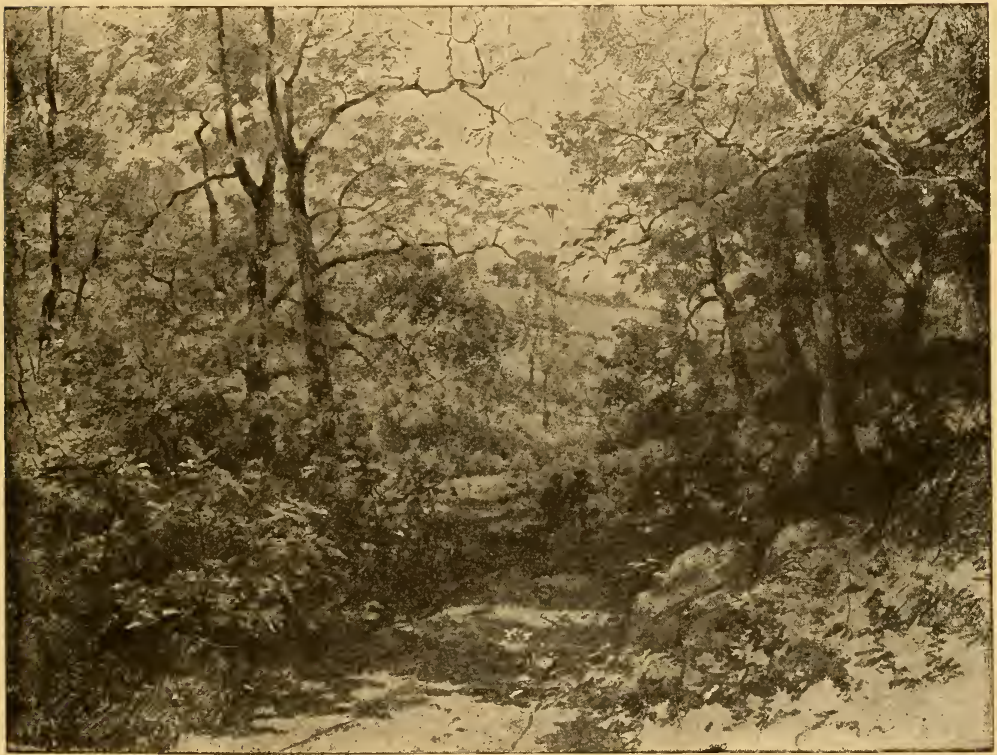

A WOOULAND PATH

broad and shallow one. The coloring, too, differs greatly. What is the explanation of these variations? Simply that at some point in their life history each of these flowers made a compact with a different tribe of insects, to which it has ever since been adapting itself. 


\section{Blossom Hosts and Insect Guests}

It the time they were both, probably, at a low stage of derelopment, visited by many insects, but adapted to no special class. They doubtless entertained vagrants such as we see to-day wandering from flower to flower,

"Kissing all buds that are pretty and sweet."

This proved a poor method for both flowers and insects. The insects might visit blossom after blossom, only to find that the nectaries had been drained by previous guests; and the flowers, since they had no special attraction to offer over any other flowers, constantly ran the risk of heing passed by and left to wither, their mission in life unfuifilled or accomplished only by the unsatisfactory process of self-fertilization.

So it came about that one day the flower that we now see with the long nectary made a compact with Mistress Butterfly. It agreed to hide its nectar in a deep, narrow pocket where Master Bombus could not possibly thrust his great head. The flower which has the shallow nectary, on the other hand, came to an agreement with Master Bombus to broaden its nectar pocket for his special benefit.

How is the flower designed for Master Bombus protected from the raids of Mistress Butterfly, say 


\section{How the Flowers Woo the Insects}

you? Possibly its blue* dress, which so charms the busy bee, is distasteful to her, or its honey not seasoned to her dainty palate.

It is not always necessary for a flower to protect its sweets. It is enough that it should be attractive to the insect it favors. Each class of insects having special races of flowers catering to its needs speedily learns where it is most welcome and most certain of entertainment.

Nearly all flowers, however, protect themselves from creeping pilferers. Common methods of doing this are by exuding a sticky substance along their stems, or covering them with a fuzzy growth. The closed gentian keeps its petals always folded for this reason.

In return for the attractions or protection offered by their special friends, the Butterfly and the Bee agreed to be faithful to their affinities and work diligently for them in the transfer of their pollen. $\dagger$ ILLOWERS AND INSECTS SUBJECT TO THE SAME LAW

Years or decades do not count in the process of

* Lubbock's careful experiments would seem to prove that bees prefer blue flowers, moths white, butterflies various shades of red, and beetles and small flies white and yellow. White and pale yellow, being more conspicuous in the dark than any other color, have been aimost universally adopted by night-blooming flowers.

t Another reason which tends to make an insect remain true to a certain species while in bloom is the fact that it can work much more rapidly by so doing, as it knows the method of approach thoroughly 


\section{Blossom Hosts and Insect Gulests}

evolution. It has probably taken centuries for each of these nectaries to become perfectly suited to the particular insect for which it was designed, but through natural selection, each century has added something to the depth of the one nectary and the breadth of the other.

It is through this law, as you remember, that the cross-fertilized flowers displace the self-fertilized ones, and in the same way the flowers that most readily adapt themselves to their insect friends survive and push aside their less well-dereloped fellows.

The insect, too, so soon as the flower begins to adapt itself especially to him, must in turn adapt himself to it. If Mistress Butterfly's tongue is too short to reach to the bottom of the flower's nectary, or if Master Bombus's head does not fit the pocket prepared for him, they both fail to obtain their food, and may possibly die of starvation.*

It is often said that the laws of Flora's kingdom,

and the flowers are apt to be close together. The industry of these little creatures is amazing. Bees have been known to visit twenty flowers a minute, and individual blossoms are frequently visited as many as thirty times a day. Nectar is generally secreted by a flower until pollination is effected, or, until the hope of this end being abandoned, the flower withers. This gives a blossom many more opportunities for cross-fertilization than if its nectar was exhausted by one visitor.

* This is true only in a limited degree. It is a great advantage to the insect to adapt himself to the Howers he feeds on, but he is not so absolutely dependent upon an individual species of flower as the species often is upon him. 


\section{How the Flowers Woo the Insects}

which thus crush the weak and protect the strong, are more just than merciful. It is true that any breach of contract between flower and insect, especially if it is persisted in, is frequently punished with death to the offending one; but this is the extreme penalty, which is often modified, as we shall learn. STAUEY A.VD PISTIL LESSONS

The stamens as well as the nectary have a lesson to teach. The function of the stamens, as you know, is the secretion of pollen. This function, however,

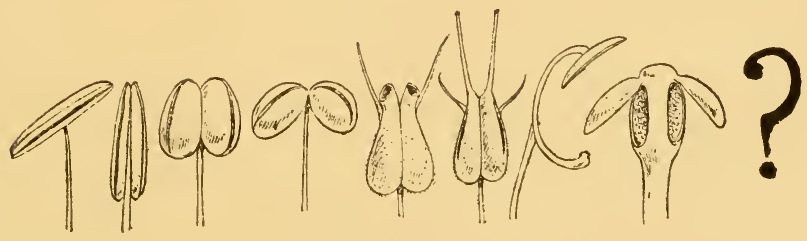

STAMENS

has no reference whatever to the external form of the stamen. Why, then, do we find such remarkable divergence as is here pictured? Another instance of adaptation to an insect? Yes. But the reason for this adaptation is somewhat different from that which caused the nectaries to vary.

The stamens differ in order to insure the transfer of their pollen. The variety of methods employed by flowers in loading their insect messengers with pollen is beyond belief. Each method requires 


\section{Blossom Hosts alli Insect Guests}

different stamen machinery, hence their varying structure.

Where moths and butterflies are the flowers' sponsors, the stamens are generally so arranged that the pollen can be deposited on the visitor's eyes or tongue; where a bee is the ally, the stamens are apt to be placed so as to come in contact with his back, head, sides, legs, or thorax.

The methods are infinite in number; there are
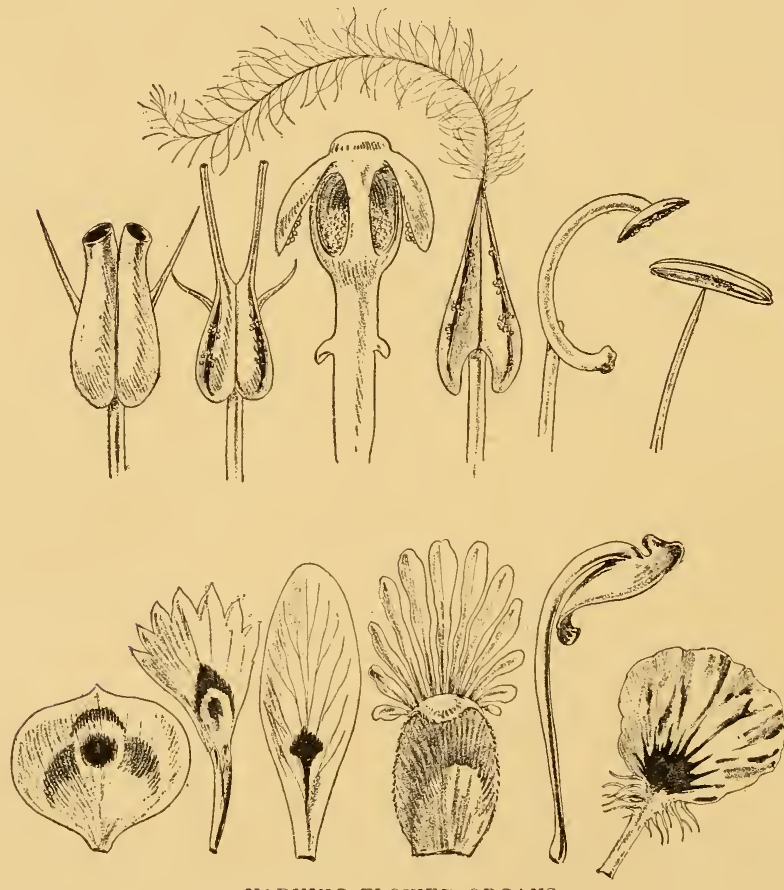

VARYING FLOWER ORGANS 


\section{How the Flowers Woo the Insects}

exploding flowers, flower traps, stamen embraces, pollen showers, pollen plasters, and pollen necklaces. Darwin discovered that the pollen of Orchis morio, whose apparent lack of nectar so puzzled Sprengel, must be actually glued to the insect in order to insure its safety. The flower, therefore, requires the insect to bore through an outer skin to reach his food. While he is thus employed, the pollen is securely fastened to him.

Pistils are no exception to the rule; they, as well as every other organ, must be modified to suit the Hower's affinity. They must be formed so as to secure and retain the pollen gifts brought to their stigmas. The variations are not so great as among the stamens, but, nevertheless, there is wonderful diversity.

The flower is even placed on its stalk in a position convenient for the insect's entrance.

IVith Darwin as our guide, then, and the insect as our key-an open sesame-the hidden treasure is revealed. It is now quite possible, as Darwin demonstrated, to look upon a Hower for the first time and from its structure foretell the method of its intended cross-fertilization-nay, more, possibly the kind or eren the species of insect to which this cross-fertilization is entrusted. 


\section{Blossom Hosts and Insect Guests}

THE GRE.AT ANGR.ECL'M

A remarkable instance of the adaptation of a flower to a single species of insect is seen in the great Angrecum orchid of Madagascar, described by Darwin. This species glorifies Darwin's faith in the truth of nis theory, and marks a notable victory in the long battle for its supremacy.

Among the host of sceptics who met his evolutionary and revolutionary theory with incredulity, not to say ridicule or worse, was one who thus challenged him shortly after the appearance of his "Fertilization of Orchids," addressing him from Madagascar substantially as follorrs: "Upon your theory of evolution through natural selection all the various contrasting structural features of the orchids have direct reference to some insect which shall best cross-fertilize them. If an orchid has a nectary one inch long, an insect's tongue of equivalent length is implied; a nectary six inches in length likerise implies a tongue six inches long. What have you to say in regard to an orchid which flourishes here in Madagascar possessing a long nectary as slender as a knitting-needle and eleven inches in length? On your hypothesis there must be a moth with a tongue eleven inches long, or this nectary would never have been elaborated," 


\section{How the Flowers Woo the Insects}

Darwin's reply was magnificent in its proof of the sublime conviction of the truth of his belief: "The existence of an orchid with a slender nectary eleven inches in length, and with nectar secreted at its tip, is a conclusive demonstration of the existence of a moth with a tongue eleven inches in length, eren though no such moth is known."

Some of us remember the ridicule which was heaped upon him for this apparently blind adherence to an untenable theory. But victory complete and demoralizing to his opponents awaited this oracular utterance when later a disciple of Darwin, led by the same spirit of faith and conviction, visited Madagascar, and was soon able to affirm that he had caught the moth, a huge sphinx-moth, and that its tongue measured eleven inches in length.

Here we see the prophecy of the existence of an unknown moth, founded on the form of a blossom. At that time the moth had not been actually seen at work on the orchid, but who shall question for a moment that had the flower been visited in its twilight or moonlight haunt the murmur of humming wings about the blossom's throat would have attested the presence of the flower's affinity ; for without the kiss of this identical moth the Angraecum must become extinct. No other moth can fulfil the 


\section{Blossom Hosts and Insect Guests}

conditions necessary to its perpetuation. The floral adaptation is such that the moth must force its large head far into the opening of the blossom in order to reach the sweets in the long nectary. In so doing the pollen becomes attached to the base of the tongue, and is withdrawn as the insect leares the flower, and is thrust against the stigma in the next blossom visited. This was clearly demonstrated by Darwin in specimens sent to him, by means of a probe of the presumable length and diameter of the moth's tongue. Shorter-tongued moths would fail to remove the pollen, and also to reach the nectar, and would thus soon cease to visit the blossom.

HOW NATURAL SELECTION PERFECTS THE ANGRACUM

The Angræecum also affords in this long pendent nectary a most lucid illustration of the present workings of natural selection. The normal length of that nectary should be about eleven inches, but, in fact, this length varies considerably in the flowers of different plants.

Let us suppose a flower whose nectary chances to be only six inches in length. The moth visits this flower, but the tip of its tongue reaches the nectar long before it can bring its head into the opening of the tube. This being a vital condition, the moth fails to withdraw the pollen; and inasmuch as the 


\section{How the Flowers Woo the Insects}

pollen is usually deposited close to the head of the moth, this flower would reccive no pollen upon its stigma. This particular blossom would thus be both barren and sterile. None of its pollen would be carried to other stigmas, nor would it set a seed to perpetuate by inheritance its shorter nectary.

Again, let us suppose
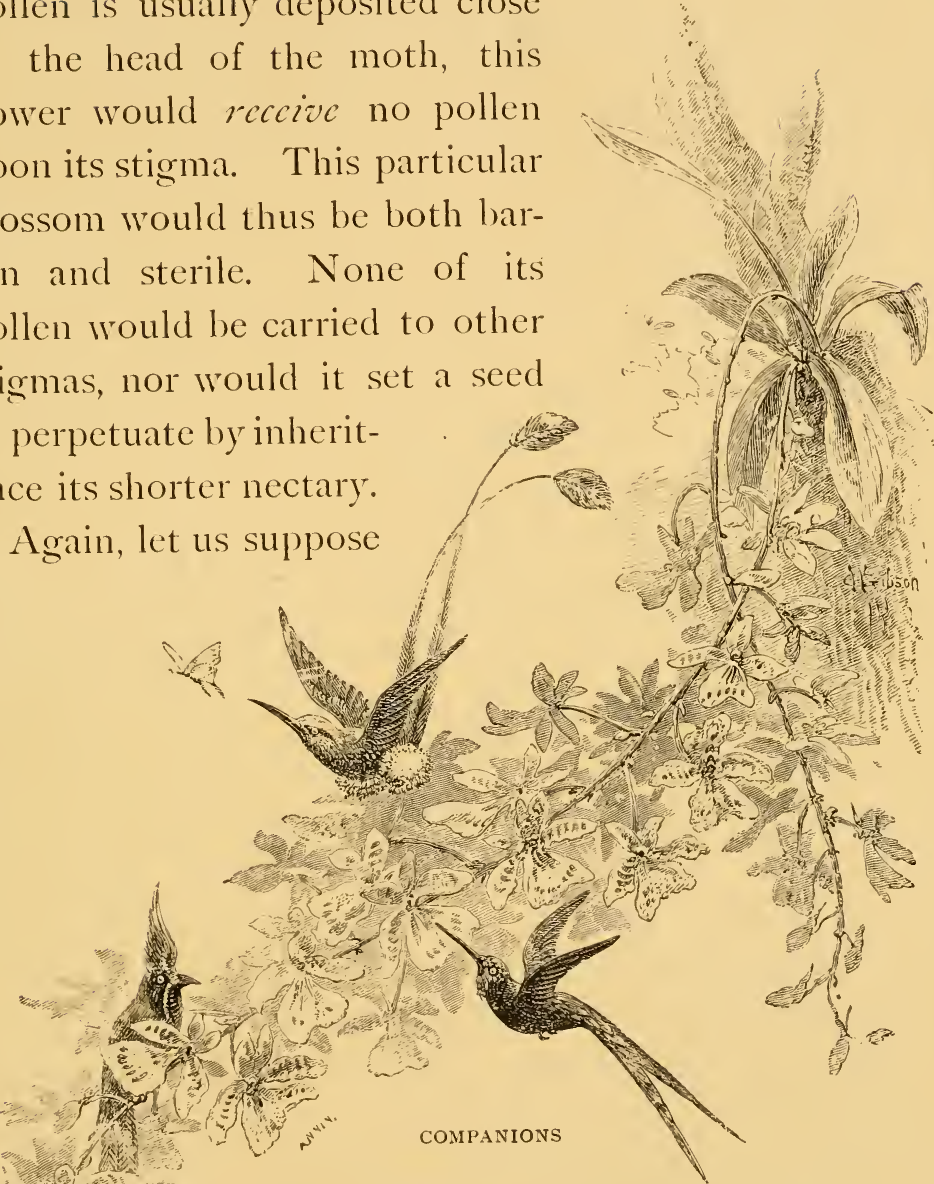

1 - 1 the variation of an extra long nectary; 4. 1 and the writer recently saw a number 4 of these orchids with nectaries thirteen Inches in length. The moth comes, and 


\section{Blossom Hosts and Insect Gulests}

now must needs insert its head to the utmost into the opening of the flower. This would insure its fertilization by the pollen on the insect's tongue; and even though the sipper failed to reach the nectar, the pollen would be withdrawn upon the tongue, to be carried to other flowers, which might thus be expected to inherit from the paternal side the tendency to the longer nectary. The tendency toward the perpetuation of the short nectary is therefore stopped, while that of the longer nectary is insured.

The Angraecum is only one of a family of plants numbering some thousands of known species, and yet nearly all of them would be doomed to extinction were it not for their legion of insect, butterfly and humming-bird friends and companions.

NATURE'S TOLERANCE

Because of the law of the "survival of the fittest," Dame Nature has gained the reputation of being cruel; but when you have studied her ways closely, you will find that she is really very tolerant. She does not approve of close or self-fertilization, yet often permits plants to retain this power as a last resort, as in the case of the dandelion. If insects fail to fertilize this blossom, it gradually separates and curls back on its stem, thus bringing the inside 


\section{How the Flowers Woo the Insects}

stigmatic-surface in contact with the outsidepollen-bearing-surface. Fertilized in this way, it is possible for the flower to produce seed without the aid of insects.

Progress is Nature's law. So long as the flowers are improving, Nature will tolerate them. She gives them many opportunities to prove their fitness to live by showing that they are of use in this busy world, where there is so much to be done. But woe to the flower or insect that, in spite of all the aids that Nature may extend, continues to degenerate. Death will surely be the penalty eventually meted out to it.

In the case of the Angrecum and its companion moth, we cannot doubt that tolerance is shown. Of course, in the extreme example cited, where the blossom is so defective as io lack five inches of the normal length, its chances of setting seed are very few; but even in this case, conditions may possibly arise which will enable it to mature its fruit.

Where a blossom falls only a little short of the requirements, it is permitted many opportunities for fertilization. For instance, the moth, whose tongue is too short to sip the honey of the flower with the thirteen-inch nectary, may, after receiving its pollen, pass on, in his search for food, to a blossom with a 


\section{Blossom Hosts and Insect Guests}

ten-inch nectary, and there gratify his appetite, and at the same time assist the defective flower in accomplishing its mission in life. This particular blossom, having now been crossed with a flower whose nectary was unusually long, its seed will probably produce blossoms of the average length.

Our knowledge of the workings of natural selection is too limited for us to lay down hard and fast rules regarding it. All that we can say is that the tendencies are in certain directions. Natural selection works only on the broadest lines and over long periods of time.

\section{NATURE'S FRUGALITY}

It is quite possible that in many of the variations we note, we see the beginning of a new species. To put it concretely, if the Angracum produced many blossoms with six-inch nectaries, they might serve to feed some species of moth with a tongue of that length, which, in return, would transfer their pollen. Should this be true, Nature, in all probability, would begin to adapt them to each other. It would be wasteful to destroy, or rather eliminate, any plant life that was worthy to exist ; and Nature is always frugal.

In all this complicated flower machinery, we find nothing unnecessary. If fragrance is a sufficient 


\section{How the Flowers Woo the Insects}

attraction to insure its perpetuation, the construction of the flower is most simple; if color is sufficient, all effort at adaptation ceases there. If a goodly store of pollen suffices to attract the insect sought and nectar is not required, all the efforts of the flower are expended on the manufacture of pollen, and no nectar is secreted. When the end in view is insured, Nature's work is finished in that particular direction. It is therefore quite usual to find plain, unattractive flowers that are more complicated in their internal mechanism than the beautiful rose or flaming peony.

The orchids, that rare race, need every attraction and the most tender care that Nature can bestow to insure their continued existence, and are therefore among our most exquisitely fashioned, as well as most wonderfully beautiful flowers.

Look where we will among the blossoms, we find the same beautiful plan of intercommunion and reciprocity everywhere demonstrated. The means appear without limit in their evolved--rather I should say, involved ingenuity.

While each family of plants is apt to favor some particular general plan in their adaptation to insects, the modifications in the various species seem almost without limit. Pluck the first flower that you meet 


\section{Blossom Hosts and Insect Guests}

in your stroll to-morrow and it will tell you a new story-in some cases a beautiful story of perfect adaptation, * in others an unfinished story, but in very instance an interesting story.

* Perfection of every part is never attained in the vegetable any more than in the animal kingdom. There is always room for improvement in some way.

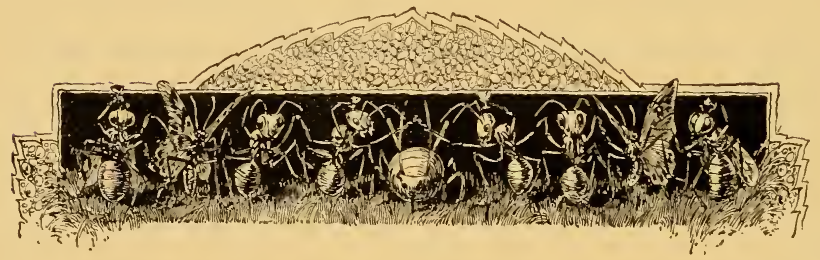




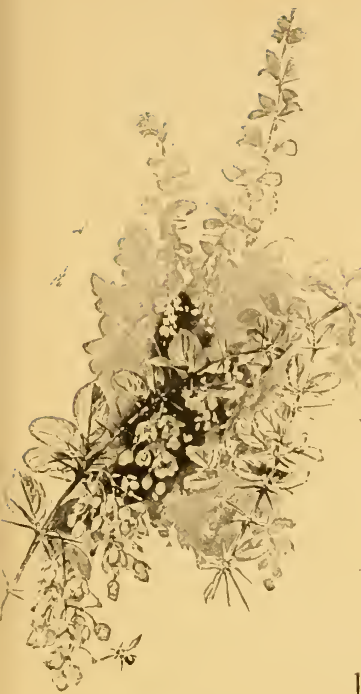

\section{Tine Barberry's Welcome to Master Bombus}

A Cluster of barberry blossoms, probably the best known species of the Barberry family, hide within their yellow cups a secret well worth learning.

Poets of all ages have loved to dwell upon the flowers-their "swete smels," exquisite forms, fragrance, and colors. The droning bees in an enviromment of fragrant bloom have moved many a poetic pen to inspiration. But it is not often that the bards have seen deep enough into the floral mysteries to immortalize the doings of the blossoms.

I recall one such allusion, however, with reference to this mischievous blossom of the barberry. How well Hosea Biglow knew its pranks!

"All down the loose-walled lanes in archin' bowers The barb'ry droops its strings o' golden flowers, Whose shrinkin' hearts the school-gals love to try With pins. 'They'11 worry yourn so, boys, bime-by." 
Those "shrinkin' hearts" of the barberry blossom, so long the wonder and amusement of children, including many children of adult growth, have, so far as I know, herein found their first and only historian-historian, but not interpreter; for neither Hosea Biglow nor his literary parent, James Russell Lowell, ever dreamed of the significance of this strange spectacle in the "shrinkin' hearts" of the barberry bloom when surprised with a point of a pin.

But the bee can tell us all about it. He has known this singular trick in the barberry for ages, and kept the secret all to himself. It is his visits in May and June to the "shrinkin' hearts" of the golden flowers that produce the clusters of brilliant scarlet acid berries of September, as we shall presently see.

At Fig. I I have shown a plan of the barberry blossom seen from below, its yellow sepals and petals open, and opposite each of the inner set, and pressed against it, a stamen. This stamen is shown below in three stages-closed, partly open, and fully open-the queer little ear-shaped lids finally drawn up, showing the pollen-pockets, and also withdrawing a portion of the pollen from the cavity. At the center is seen the circular tip of 


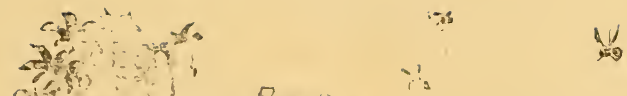

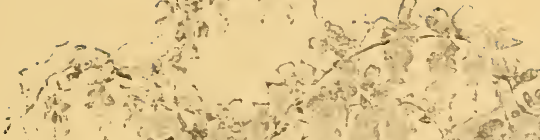

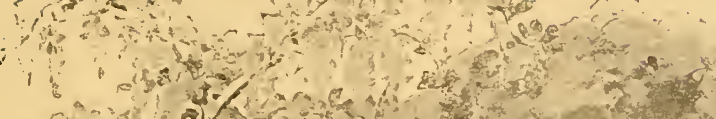

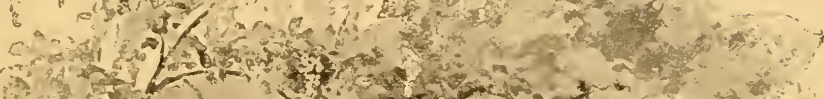

cin

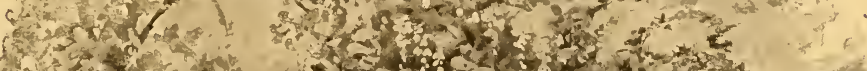

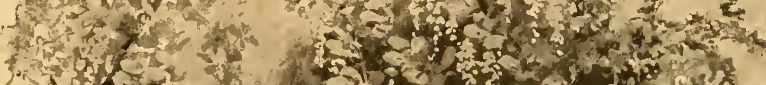

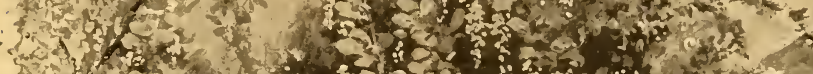

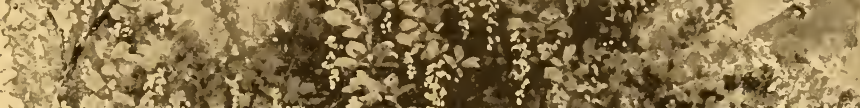

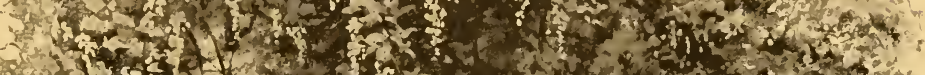

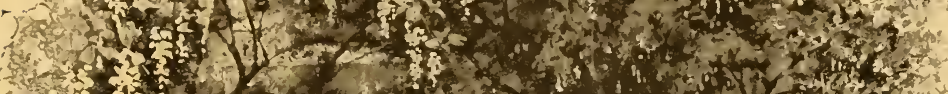

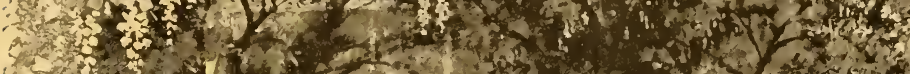

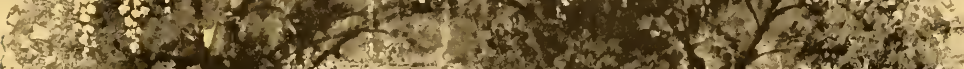

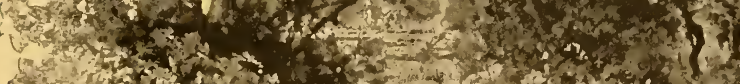

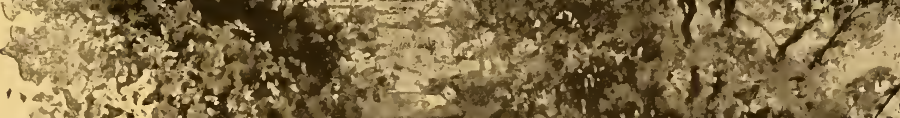

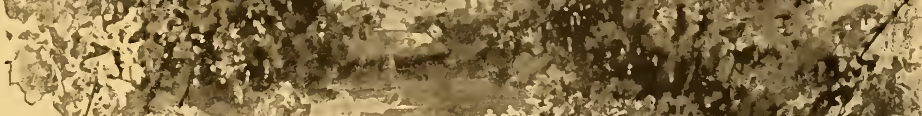

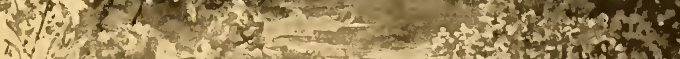

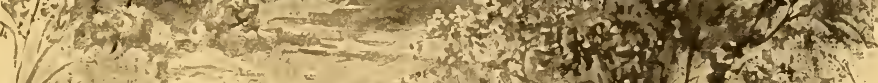

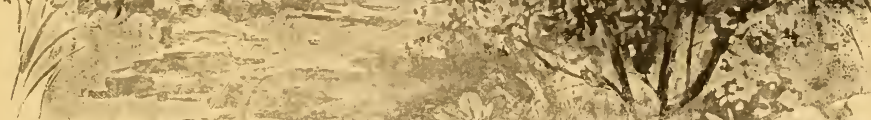

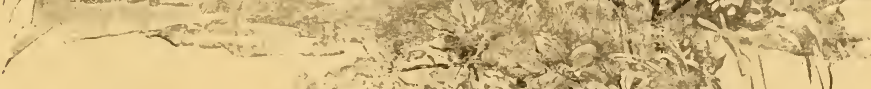

"In archin' bawars?

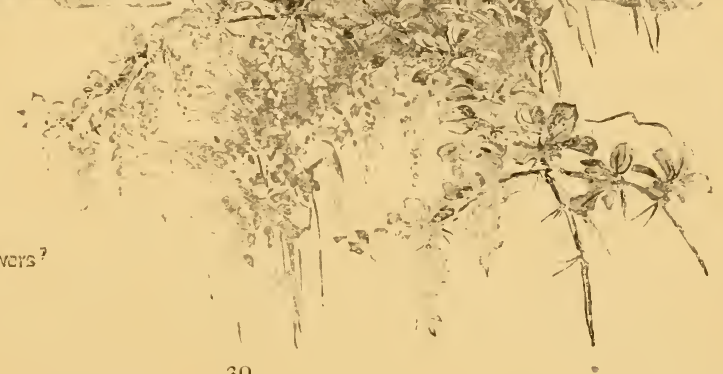


the orary, which finally becomes the berry - that is, when the little scheme here plainned has been fulfilled. This circular form represents the tip of the ovary, and the little toothed rim the stigma. Now, what is the intention here expressed? This construction represents a plan, first, to invite a bee. This is done, as in all flowers visited by insects, by its color, its fragrance, and its nectar, which is secreted in a gland at the base of each petal, near the centre of the flower; secondly, to make that

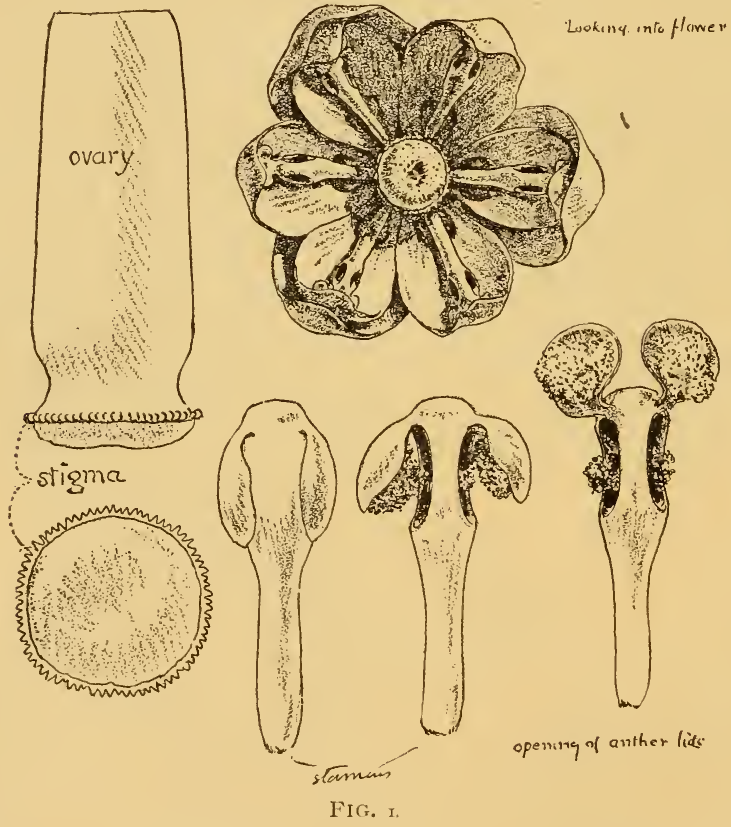




\section{The Burberry's Welcome to Master Bombus}

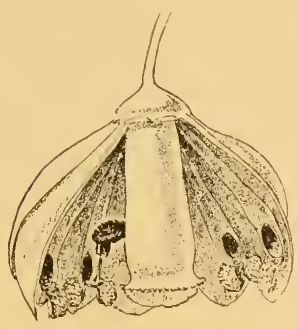

A

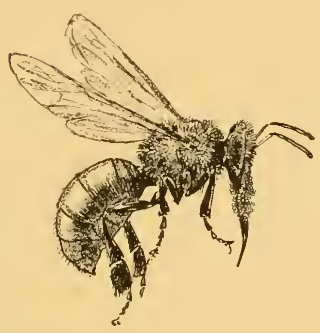

C
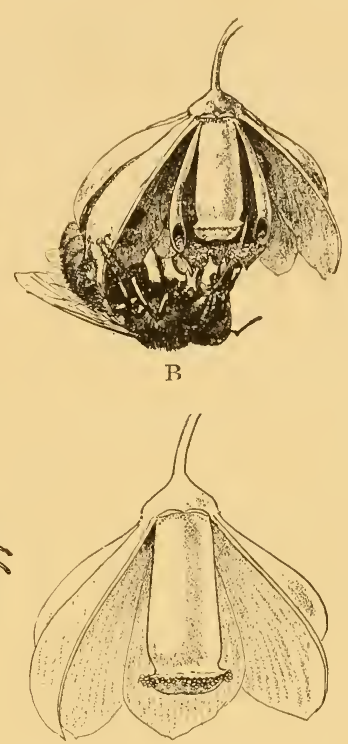

FIG. 2.

bee bear away the pollen; thurdly, to cause that same bee to place this pollen on the stigma rim of the next flower he visits. In Fig. 2 we see how beautifully this plan is carried out by the insect. It A we see the same flower cut open sideways, the waiting, expectant stamens tucked away at the sides, leaving a free opening to the base of the flower. Now comes our bee. He must needs hang back downward to sip at the drooping flower. As his tongue enters, and finally touches the base 


\section{'Blossom Hosts and Insect Guests}

of these stamens, clap! they come one after another against his tongue and face, and there deposit their load of pollen (B). The bee, who has doubtless got over his surprise at this demonstration-if, indeed, he ever had any-now flies to another blossom, perhaps on the same cluster (C). Entering it as before, the notched edge of the stigmatic rim comes in contact with the pollen on his tongue and face, and the flower is thus fertilized by pollen from another barberry blossom, the intention of the flower now perfectly realized in crossfertilization.
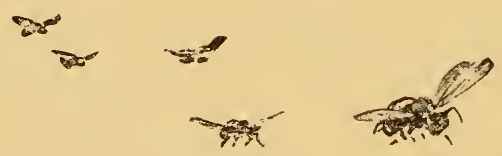


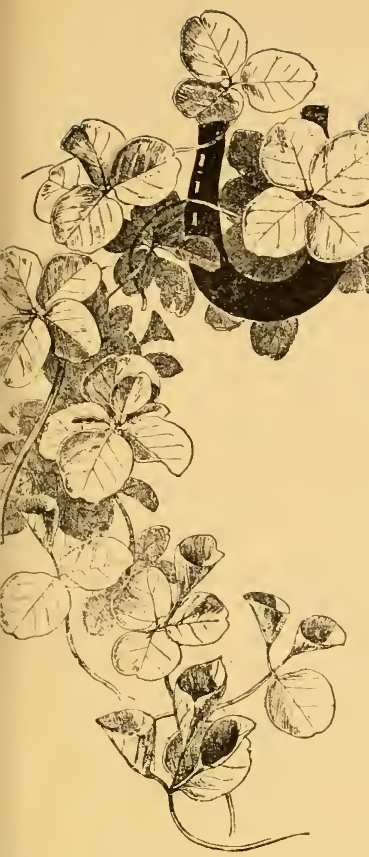

$$
\begin{gathered}
\text { The Honered Clover-The } \\
\text { "Beriak's Tick" }
\end{gathered}
$$

Tine red clover owes its existence to the "epicurean of June," if I may so speak of the bumblebee. This fastidious plant, it is well known, would become extinct, perish in celibacy, without the sanction of this busy little marriage-priest.

Like many other members of the Pulse family, it has what would seem to us a rude welcome for its guests. A shot-gun lies in wait for them loaded to the muzzle with pollen powder, and with the trigger carefully set, so that they cannot fail to press it while searching for sweets.

In an endeavor to establish a clover crop in Australia, it was discovered that while the first sowed growth from imported seed thrived luxuriantly, it ripened no seed, and thus defeated its selfperpetuance; and all because Bombus was not 
consulted. The importation of a few shiploads of bumblebees, however, insured an abundant crop. Thus, when this "breezy hum" of the Bombus is heard no more in our meadorss, we must say goodby to the red clover.

And now, apropos of such an extremity, I am reminded of that remark of Darwin, who traces back a little farther to the souree of our obligation. Clover, he reasons, depends upon the number of cats. No cats, no clover. Clover will not produce seed unless its flowers are fertilized by bumblebees; the nests of the bees are eagerly destroyed by mice; cats kill the mice--thus the bees are spared, and having these, the clover is insured. Very good! "Cats and clover" as a context may be more alliterative, but most of us.who are at all given to sentiment will welcome the interposing links in the chain of cause and effect.

By what endless devices does Nature thus secure her ends! The design beneath the construction of any' flower we may pluck-often the very commonest by the roadside-is a profound riddle, often unanswerable until we await the oracle of its chosen mouthpiece, perhaps the one confidant for whom it has been adapting and shaping itself through the ages. 


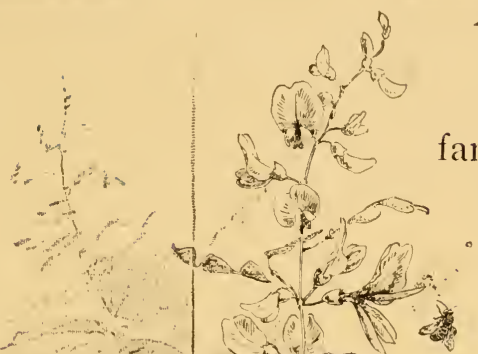

AN INTERESTING
IAGBOND

Here is another familiar face. We all know himthe tramp of the und erwoods; for who, in spite of himself, has not brought home the "beggar's ticks"? Dismodium accuminatus the records have him down. Look out for him in the rogue's gallery. See him now! with clustered leaves and

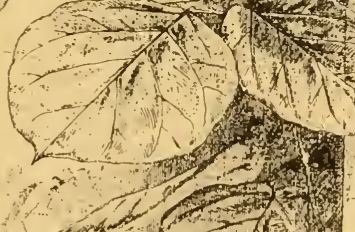

$x+30$ and

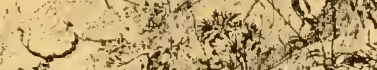

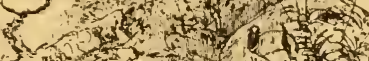

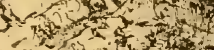

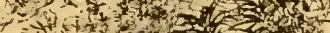

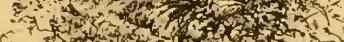

Fen

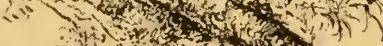

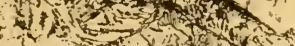

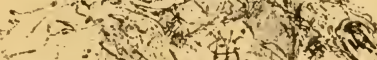

saucy chains of seed-pods and airy tips of pink pea-blossomed flowers!

So, so, my impetuous ragabond, you have a slap for all, for tiny bee and fly as well as me. J'ou secure your posterity by the same 45 
aggressive arts with which you perpetuate their vagrancy. A little fly alights upon the small pink blossom, when, lo ! the flower explodes, the insect is greeted with a slap on the face or breast, and a dab of dust in his eyes. For this flower, too, is a veritable trap, delicately set. Upon the slightest touch, the loaded spring--consisting of the rigid column of filaments enclosing the young pod-is released from the overlapping petals, and the anthers hurl their shower of pollen upon the body of the intruder. But observe the wise adjustment beneath all this mechanism. The stigma-the organ through which the seeds are fertilized--projects a little beyond the anthers, and is the first to come in contact with the insect, and thus gets a supply of pollen from the previously visited flower.

It is the pollen-collecting bees which the Beggar's Tick wishes to attract. The plant, therefore, has directed its energies, through the ages, to increasing its store of golden powder rather than to laying up sweets, its food being intended for unborn generations, not for the insect that does its bidding.

In the lucerne, Medicago sativa, the flowers are similarly explosive, and it has been observed that bees find this continual belaboring unpleasant, and 


\section{The Beggar's Tick}

contrive means of obtaining their nectar without touching the trigger-a skilful operation, it would seem, when we consider that the touch of a butterfly's tongue is commonly sufficient

to explode the flower.

The woad-waxen, Genista tinctoriar, the identical "whin" of the English downs, now sparingly naturalized
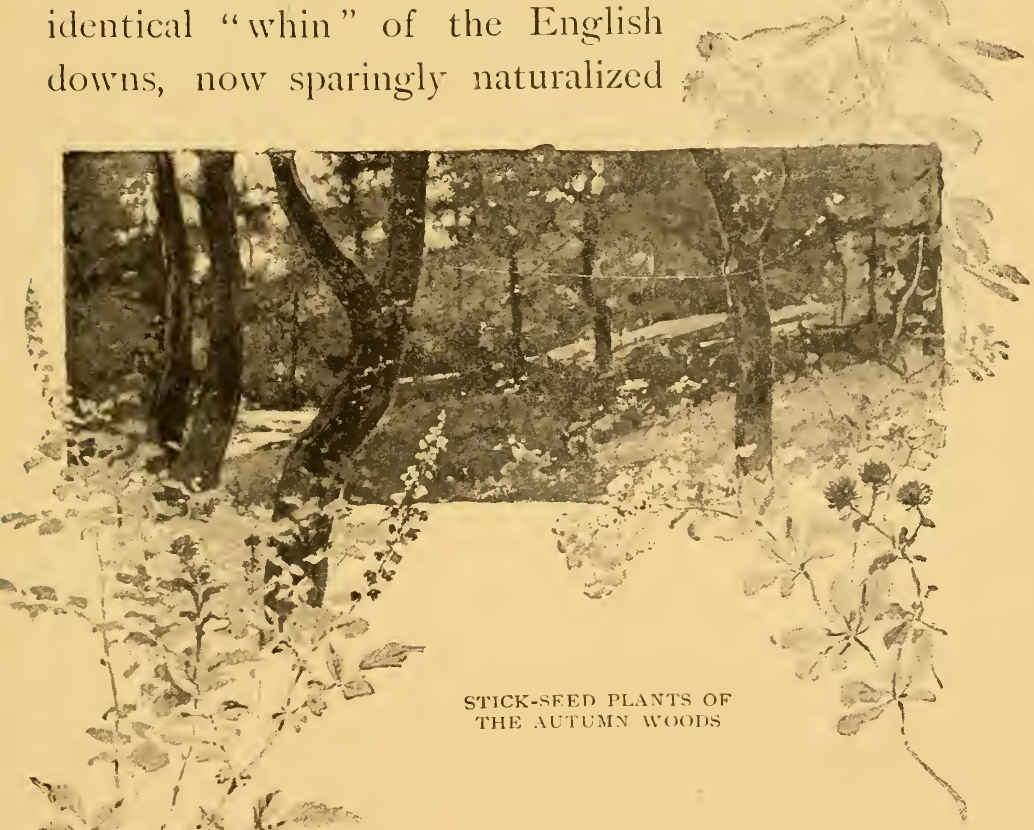

in some sections of New England, affords, perhaps, in the large size of its flowers and rigid tension, the best illustration of this peculiar explosire mechanism to be found among our flora, and, like the various 
desmodiums, is well worth a little study in its haunts. The two forms of the flower, both before and after - yplosion, are easily observed upon almost any single plant.

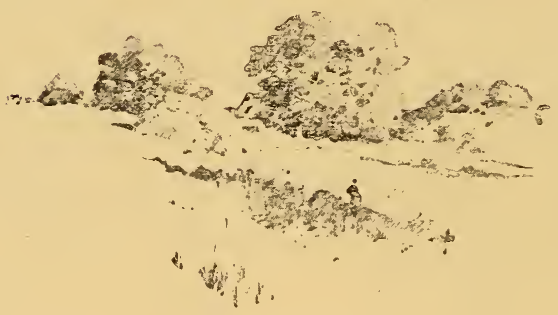




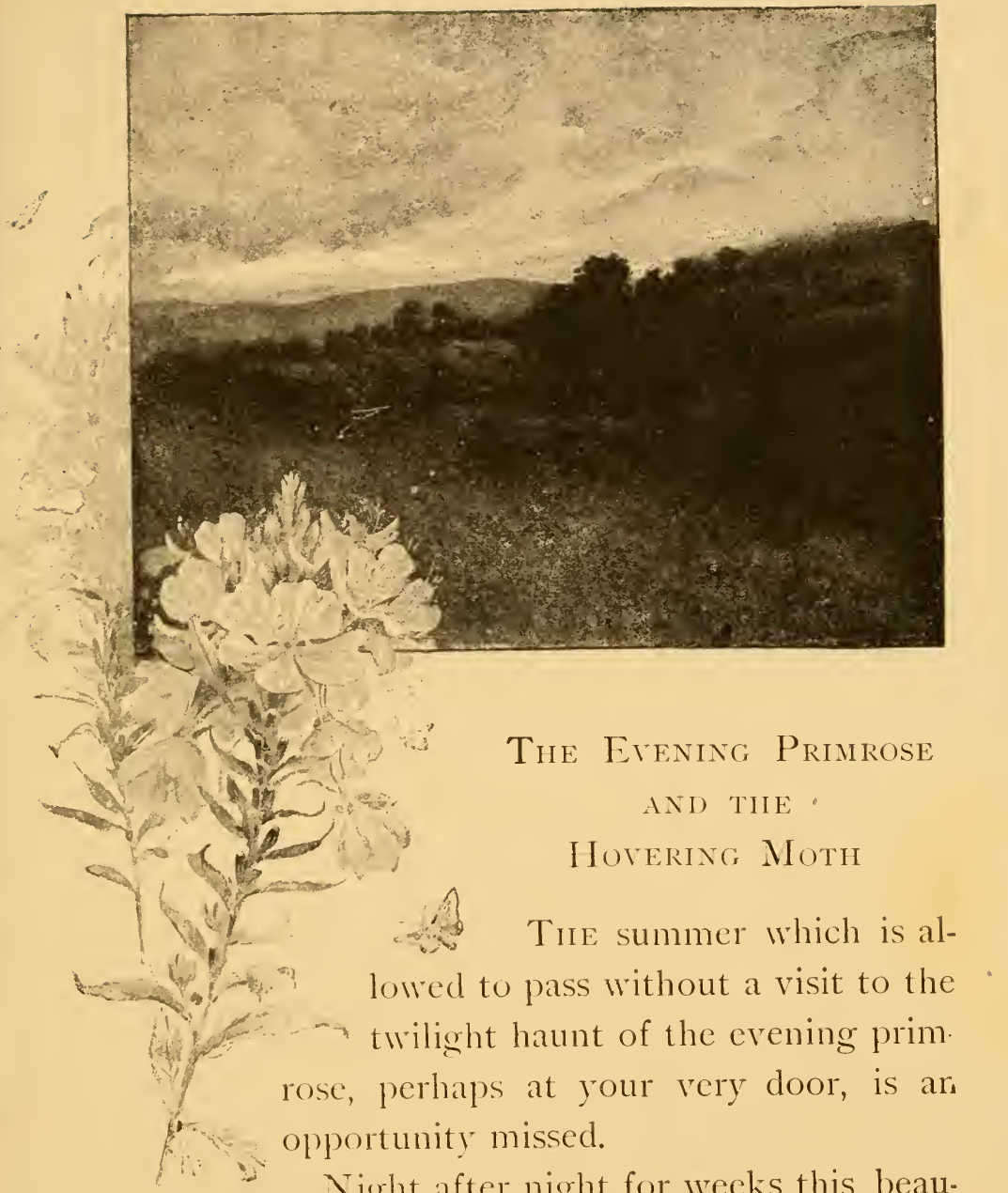

Night after night for weeks this beautiful member of the Primrose family breathes its fragrant invitation as its luminous blooms flash out one by one from the clusters of buds in the gloom, 
as though in eager response to the touch of some wandering sprite, until the darkness is lit up with their luminous galaxy - that beautiful episode of blossom consciousness and hope so picturesquely described by Keats.

"A tuft of evening primroses

O'er which the wind may hover till it dozes,

O'er which it well might take a pleasant sleep,

But that 'tis ever startled by the leap

Of buds into ripe flowers."

Nor is it necessary to brave the night air to witness this sudden transformation. A cluster of the flowers placed in a vase beneath an evening lamp will reveal the episode, though robbed of the poetic attribute of their natural sombre environment and the murmuring response of the twilight moth, a companion to which its form, its color, and its breath of perfume and impulsive greeting are but the expression of a beautiful divine affinity.

The primrose presents the peculiar phenomena of two kinds of buds, as shown in the accompanying drawing.

Regarding these varying buds, I once received the following letter :

"I read in 'Harper's Young People' your piece about the evening primrose, and found the little moth and the catterpilers, what I never seen before: 


\section{The Evening Primrose and the Hovering Moth}

but they is one thing what you never tole us about yit. Why is it that the buds on so meny evening primroses swell up so big and never open? Some of them has holes into them, but I never seen nothing cum out."

This same question must have been mentally propounded by many observers who have noted this singular peculiarity of the buds - two sorts of buds, one of them long and slender, and with a longer tube; the other short and stout, with no tube at all -both of which are shown in proper proportion in my illustration. It is well to contrast their outward form, and to note wherein they differ. In the normal or

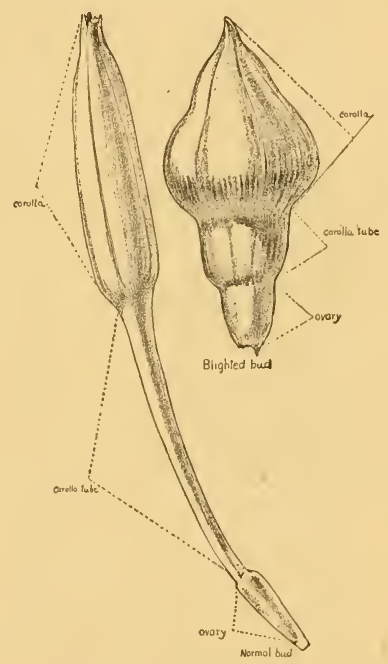
longer bud the tube is slender, and extended to a length of an inch or more, while in the shorter specimen this portion is reduced to about a fifth or a sixth of that length, while the corolla enclosed within its sepals is much shortened and swollen.

The difference in the shape and development of 


\section{Blossom Hosts and Insect Gulests}

these two buds is a most interesting study, as bearing upon the conscious intention of the flower as an embodiment of a divine companion to an insect. What is the intention involved in the construction and habit of this flower?

What are we to infer from the shape of our even-

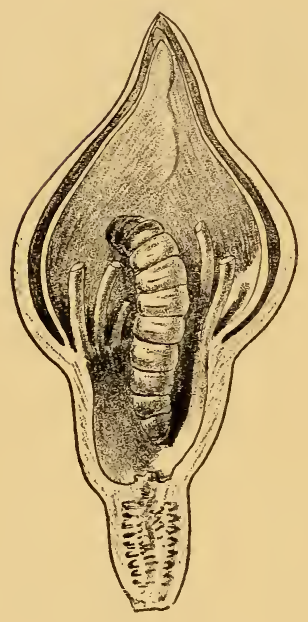
ing primrose? Its tube is long and slender, and the nectar is secreted at its farthest extremity. Only a tongue an inch or so in length could reach it. What insects have tongues of this length? Moths and butterflies. The primrose blooms at night, when butterflies are asleep, and is thus clearly adapted to moths. The flower opens; its stigma is closed; the projecting stamens scatter the loose pollen upon the moth as it sips close at the blossom's throat, and as it flies from flower to flower it conveys it to other blossoms whose stigmas are matured. The expression of the normal bud is thus one of affinity and hope.

Our friend just quoted mentions having seen "holes" on the other swollen buds, and there is 


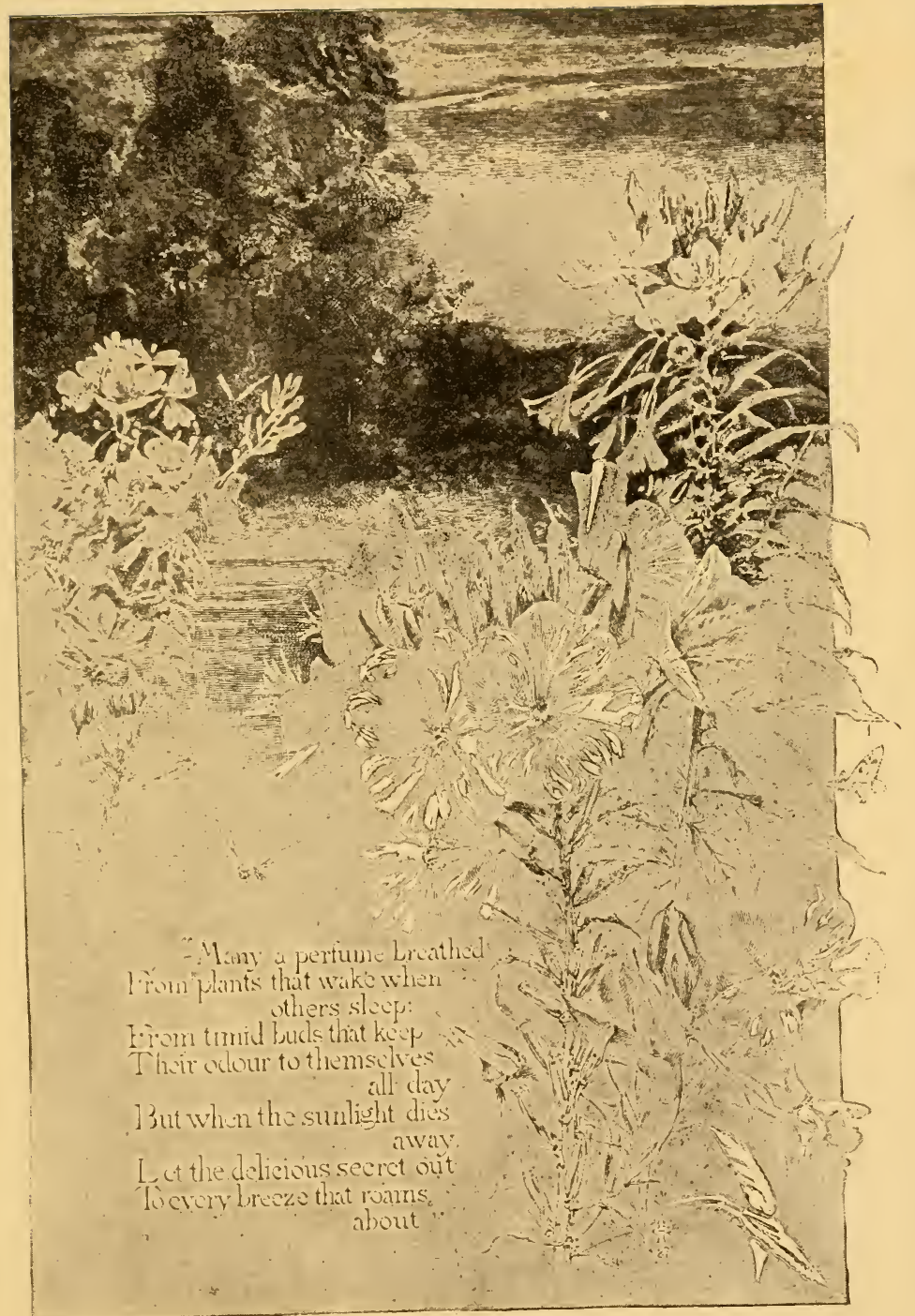




\section{Blossom Hosts and Insect Guests}

certain to be a hole in every one of them at its maturity. But let us select one which is as yet entire. If with a sharp knife-point we cut gently through its walls, we disclose the curious secret of its abnormal shape_- "the worm i' the bud," as shown in my accompanying sketch-and what an eloquent

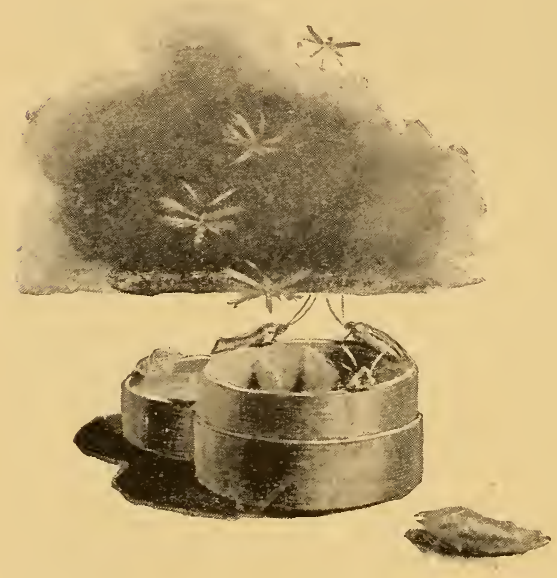
story of blighted hopes its interior condition reveals! This tiny whitish caterpillar, which we disclose in the petal dungeon, has been a prisoner since its birth, during the early growth of the bud. One by one the stamens and also

the stigma have been devoured for food, until the mere vestiges of them now remain. With no stamens to bequeath pollen and no stigma to welcome other pollen, what need to open, what need to elongate a corolla tube for the tongue of a moth whose visit could render no functional service? So thus our blighted buds refuse to open, where blooming would be but a mockery. 


\section{The Evening Primrose and the Hovering Moth}

This tiny caterpillar has a host of evening primrose blossoms laid to his door. When full grown he is nearly a third of an inch in length, at which time he concludes to leave his life-long abode, which explains $\mathrm{t}$ h $\mathrm{e}$ "hole" through the base of
the bud. If we gather a
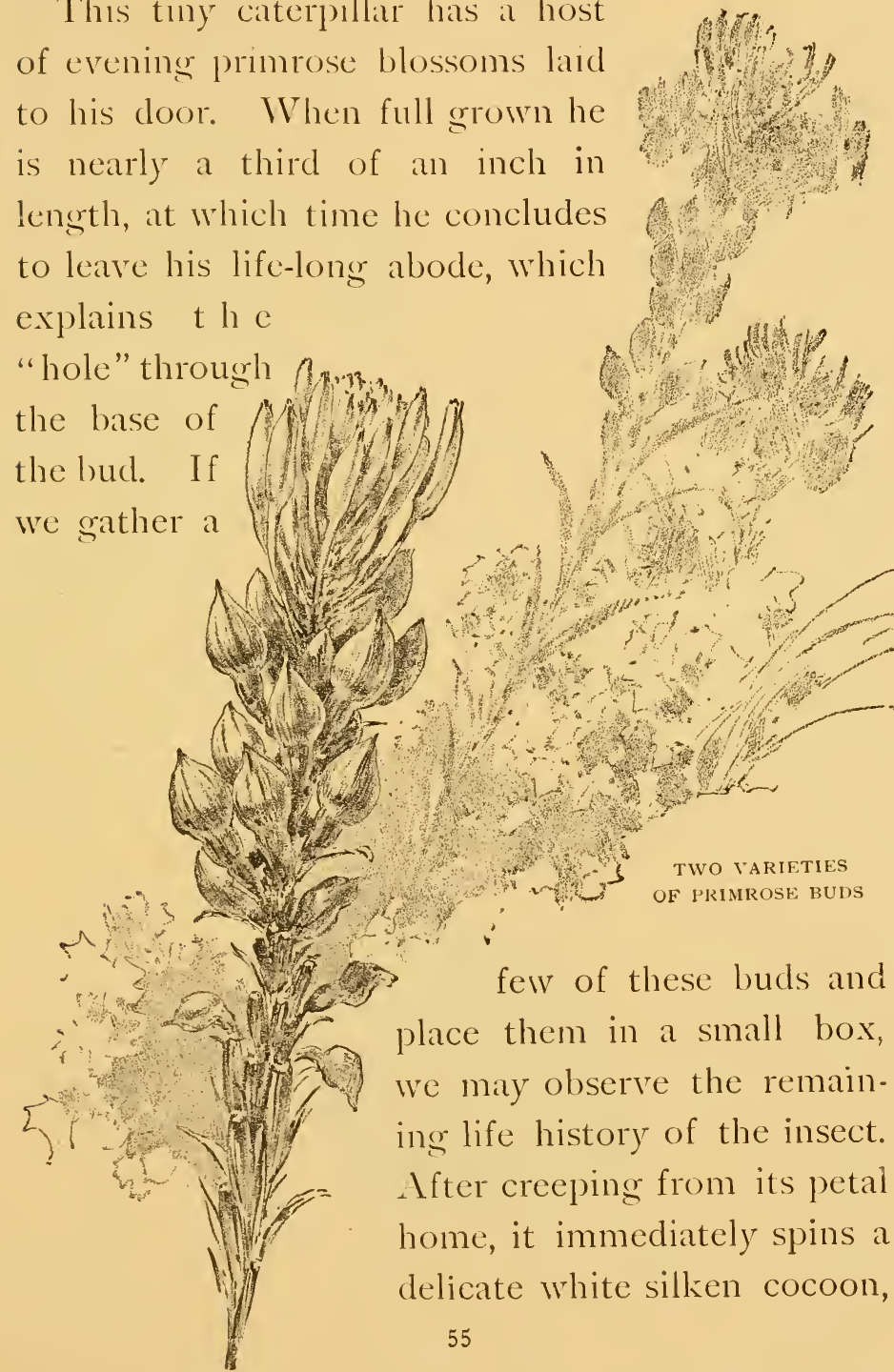


\section{Blossom Hosts and Insect Gulests}

and within a day or so changes to a chrysalis. At the expiration of about a fortnight, as we open the box, we are apt to liberate one or more tiny gray moths, which, upon examination, we are bound to confess are a poor recompense for the blossom for which they are the substitute.

This little moth is shown very much enlarged in the accompanying tail-piece. Its upper wings are variously mottled with gray and light brown, and thickly fringed at their tips, while the two lower wings are like individual feathers, fringed on both sides of a narrow centre. These and other characters ally the insect with the great group known as the Tincide, of which the common clothes-moth is a notorious example.

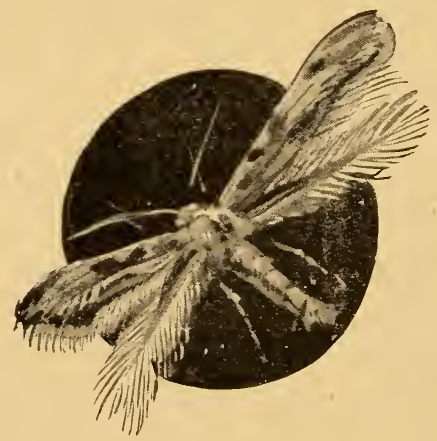




\section{The Noonima Lesson of the Printose}

HAving learned the twilight lesson of the waiting bud, go out now in the hot, sunny noontime and stroll among your withered primroses, and see what they can teach you.

These faded blooms, in which so few of us have the slightest interest, may often be seen hanging like a chime of bells on the drooping stems for twenty-four hours after they first bow their heads. Who has guessed their pretty mystery?

Is this a mere withered, useless blossom that droops upon its stem? Is it not rather the prettiest luminous fairy tent that ever sheltered a day dream? Last night, when its four green sepals burst from their cone, and sprang backward to release their bright, glossy petals, a small moth quickly caught the signal and settled in quivering 


\section{Blossom Hosts and Insect Gulests}

contentment, sipping at its throat. Its wings were of the purest rose-pink, bordered with yellow.

All through the night it fluttered among the fresh opening flowers, one of a countless host of feathery nocturnal moths and "millers." But as the sunrise has stolen upon these primroses, the fickle broods have all forgotten the flowers and dispersed afar. "All," did I say? Oh, no ; not all. Let us turn to our withered blossoms and, one by one, look within their bells. Here is one that falls even at our approach, plainly the blossom of night before last. We will turn our attention only to last night's flowers.

Many show no peculiarity, but at length we find one that appears to have an extra petal folded within its throat, and upon opening the folds, we disclose our faithful nursling with pink and yellow wings, whom we saw last night fluttering from flower to flower, sipping its sweets and bearing its golden pollen from cup to cup. The carliest twilight sipper, that even on the approach of dawn is loath to leave the flower, and creeps into the wilted bloom, where it remains concealed through the following day, and doubtless occasionally falls with it to the ground.

In the color of its markings we find an outward 


\section{The Noollday Lesson of the Primrose}

expression of its beautiful sympathy, the yellow margins of the wings, which protrude from the flower, being quite primrose-like, and the pink being reflected in the rosy hue which the wilting primrose petals so often assume, especially at the throat.

These pretty moths are by no means rare. A careful search is quite certain to disclose a number of them. I once found three secreted in the Howers of a single plant.

The progeny of our tiny pink and yellow moth will feed upon the young seed-pods of the primrose at a later date. They are smooth, green caterpillars which so exactly resemble in size and shape the seedpods themselves that even a vireo or worm-eating warbler, who is supposed to know a green caterpillar when he sees one, might perch among these without a suspicion, except, perhaps, at the tickling of its feet by the rudely touched victim.

Nearly all insect-eating birds are very fond of these green caterpillars, so that doubtless none would ever reach the moth stage, and the primroses would be robbed of their benefactors if their protective coloring was less perfect.

Even in winter, when the stories of the waiting bud, the blighted blossom, the fairy tent, and the dainty pod are finished, the primrose still has a 


\section{Blossom Hosts and Insect Guests}

lesson to teach-a lesson of wonderful beauty in its perfectly symmetrical leaf clusters, carpeting the earth with exquisite complex spiral stars, geometrical in their arrangement and perfect patterns for the modeller, sculptor, decorator, or wood carver.

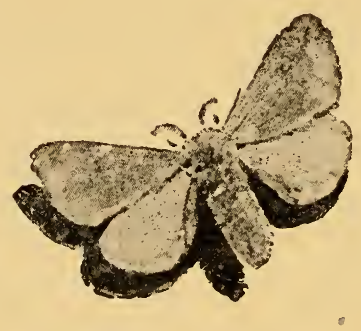


The Ridnle of the Bluets Guessed by Buth Bees axd Butterflies

Tine little Quaker-ladies of the

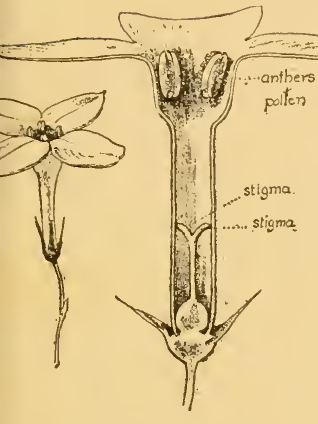

FIG. I.

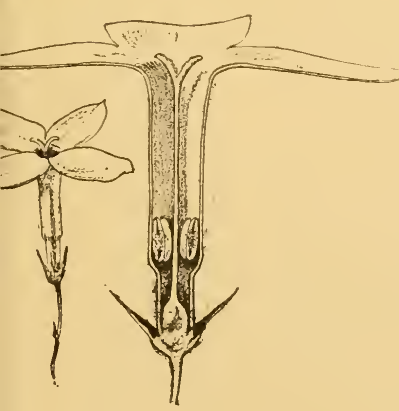

FIG. 2. fields are by far the most interesting of the Madder family, and are also the best examples of what are known as "dimorphic" "heterostyled," or two-formed flowers that we have in our wild garden.

Ve all know these pretty, dainty bluets, whose galaxy of white or blue stars tints whole meadows like a light snowfall. Perhaps we may have chanced to notice that the flowers are not all constructed alike, but the probabilities are that we have secn them all our lives without discovering this fact, obvious as it is to the most casual observer. 


\section{Blossom Hosts and Insect Guests}

If we pluck a few from this dense cluster beside the path, we observe that the throat of each is swollen larger than the tube beneath, and is almost closed by four tiny yellow anthers, Fig. I. The next and the next clump may show us similar flowers; but after a little search we are sure of finding a cluster in which a new form appears, as shown in Fig. 2, in which the anthers at the opening are missing, and their place supplied with a little forked stigma! The tube below is larger than the first flower for about two-thirds its length, when it suddenly contracts, and if we cut it open we find the four anthers secreted near the wide base of the tube. What does it mean, this riddle of the bluets? This is simply the little plan which the Houstonia has perfected to insure its cross-fertilization by an insect, to compel an insect to carry its pollen from one flower and deposit it upon the stigma of another. Once realizing this as the secret, we can readily see how perfectly the intention is fulfilled.

In order to make it clear, I have drawn a progressive series of pictures, which hardly require description. The flowers are not highly developed enough to have a special insect sponsor. They are visited by various small bees, butterflies and other insects. At the left is an insect just alighting 


\section{Blossom Hosts and Insect Guests}

on a clump of the blossoms of the high-anther form indicated below it. The black probe represents the insect's tongue, which, as it seeks the nectar at the bottom of the tube, gets dusted at its thickened top with the pollen from the anthers. We next see the insect flying away, the probe beneath indicating the condition of its tongue. It next alights on clump No. 2, in which the flowers happen to be of the high-stigma form, as shown below. The tongue now being inserted brings the pollen against the high stigma, and fertilizes the flower, while at the same time its tip comes in contact with the low anthers, and gets pollen from them. We next see the insect flying to clump No. 3 , the condition of its tongue being shown below. Clump No. 3 happens to be of the first low-stigma form of flowers, and as the tongue is inserted the pollen at its tip is carried directly to the low stigma, and this flower is fertilized from the pollen from the anthers on the same level in the previous flower. And thus the riddle is solved by the insect. From clump to clump he flies, and through his help each one of the pale blue blooms is sure to get its food, each flower fertilized by the pollen of another.

Another beautiful provision is seen in the difference in size of the pollen-grains of the two flowers, 


\section{The Riddle of the 'Bluets}

those of the high anthers being much larger than those from the lower anthers. These larger grains are intended for the high stigma, which they are sure of reaching, while those of smaller size, on the top of the tongue, which should happen to be wiped off on the high stigma, are too small to be effective for fertilization, accomplishing their purpose only when deposited on the low stigma to which they are adapted.

The flowers with high stigmas ard ow stamens are never found on the same plant as those with low stigmas and high stamens-in fact, the two forms grow in separate patches.

The stigma of either variety is rarely exactly the same length as the stamen producing the pollen which will fertilize it, but the variation is very slight.

The little meadow fritillary, Brenthis bellona, is the chief butterfly visitor of the bluets, but it is not nearly so effective a worker as the small bees that also sip these sweets, since it is apt to fertilize only the short-styled blossoms, avoiding the stigma in the long-styled flowers, and sipping their honey from the side.

Much the same mechanism that distinguishes the bluets may be seen in the flax, the partridge-berry, the bouvardia, and the cowslip. 


\section{Blossom Hosts and Insect Guests}

The purple loosestrife, Lythrum Salicaria, produces flowers whose stamens and pistils occur in three different lengths. In this species only pollen from the longest stamens can fully fertilize the longest pistils; only that from the shortest stamens the shortest pistils, and only that from the mediumlength stamens the medium-length pistils.

The common wood-sorrel and the blue pickerel weed also produce trimorphic or three-formed flowers.

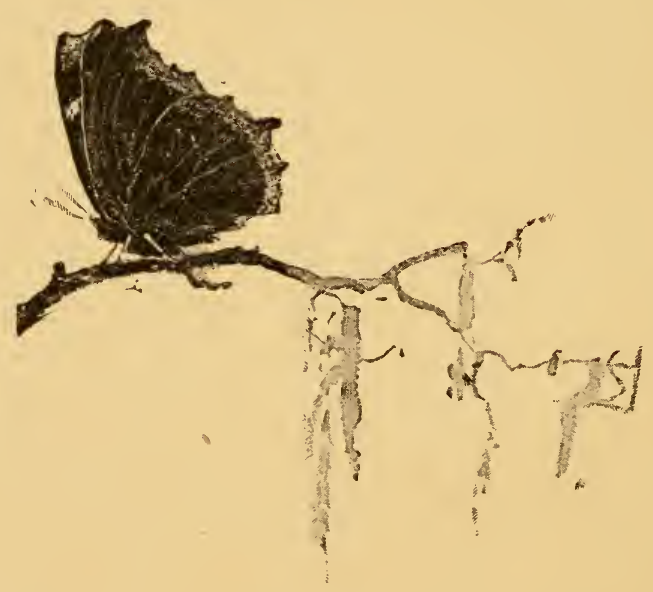




\section{Blossom Hosts and Insect Guests}

closely. If we pluck one of the blossom's heads and keep it in a vase overnight, we shall probably see on the following morning a tiny yellow ring of pollen encircling the outer edge of the cone. In this way only are we likely to see the ring in its perfection, as in a state of nature the wind and insects rarely permit it to remain.

If we now with a sharp knife make a vertical section, as shown at Fig. I, we may observe

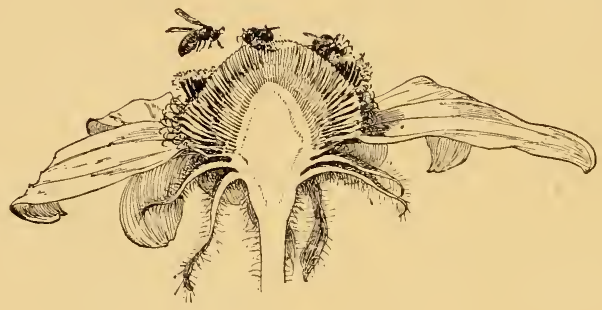

FIG, I.

the conical receptacle studded with its embryo seeds, each bearing a tiny tubular blossom. Three distinct forms of these flowers are to be seen. The lower and older ones are conspicuous by their double feathery tails, the next by their extended anthers bearing the pollen at their extremity, and above these again the buds in all stages of growth. These various states are indicated in Fig. 2.

As in all the Composita, the anthers are here united in a tube, the pollen being discharged within. 


\section{Composite Manners}

At the base of this anther-tube rises the pistil, which gradually elongates, and like a piston forces out the pollen at the top. Small insects, in creeping over the cone, quickly dislodge it. In the next stage the anthers have withered, the flower-tube elongated, and the top of the two-parted pistil begins to protrude, and at length expands its tips, disclosing at the centre the stigmatic surface, which
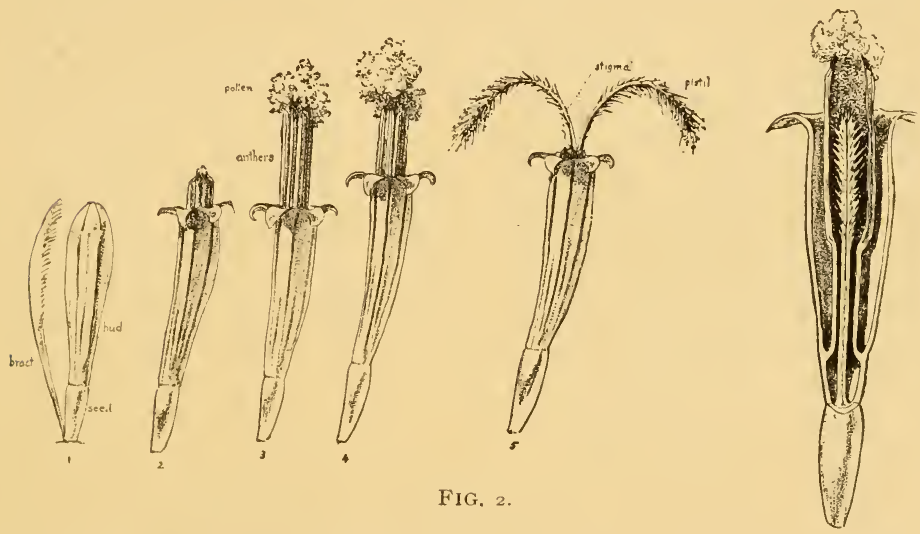

has until now been protected by close contact, as shown in the section at the right of Fig. 2.

A glance at Fig. 2 will reveal the plan involved. The ring of pollen is inevitably scattered to the stigmas of the neighboring flowers, and cross-fertilization continually insured. Similar contrivances are to be found in most of the Compositæ, through the same method being variously applied. 


\section{Blossoll Hosts and Inseit Guests}

The practice followed by the Compositx of grouping many small flowers in one head is unrivalled for utility in the floral world. It is, however, only one of the many thrifty traits which have enabled these hardy folk to penetrate to all quarters of the globe. They spare no effort to insure success, attracting both pollen-gatherers and nectarseekers, and still, not quite certain but that both these classes may sometime fail them, reserving the power of self-fertilization for such an extremity.

Their method, too, of scattering their seed as shown in the dandelion and thistle has aided their march around the world. One cannot help admiring their persistency and delighting in their beauty, despite the farmer's lament.

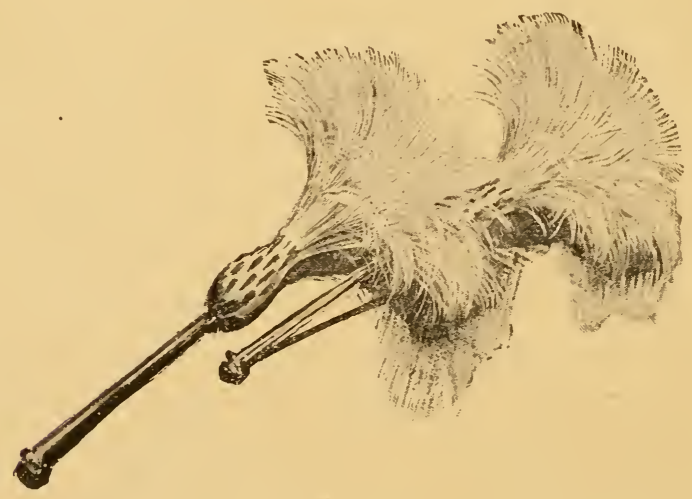




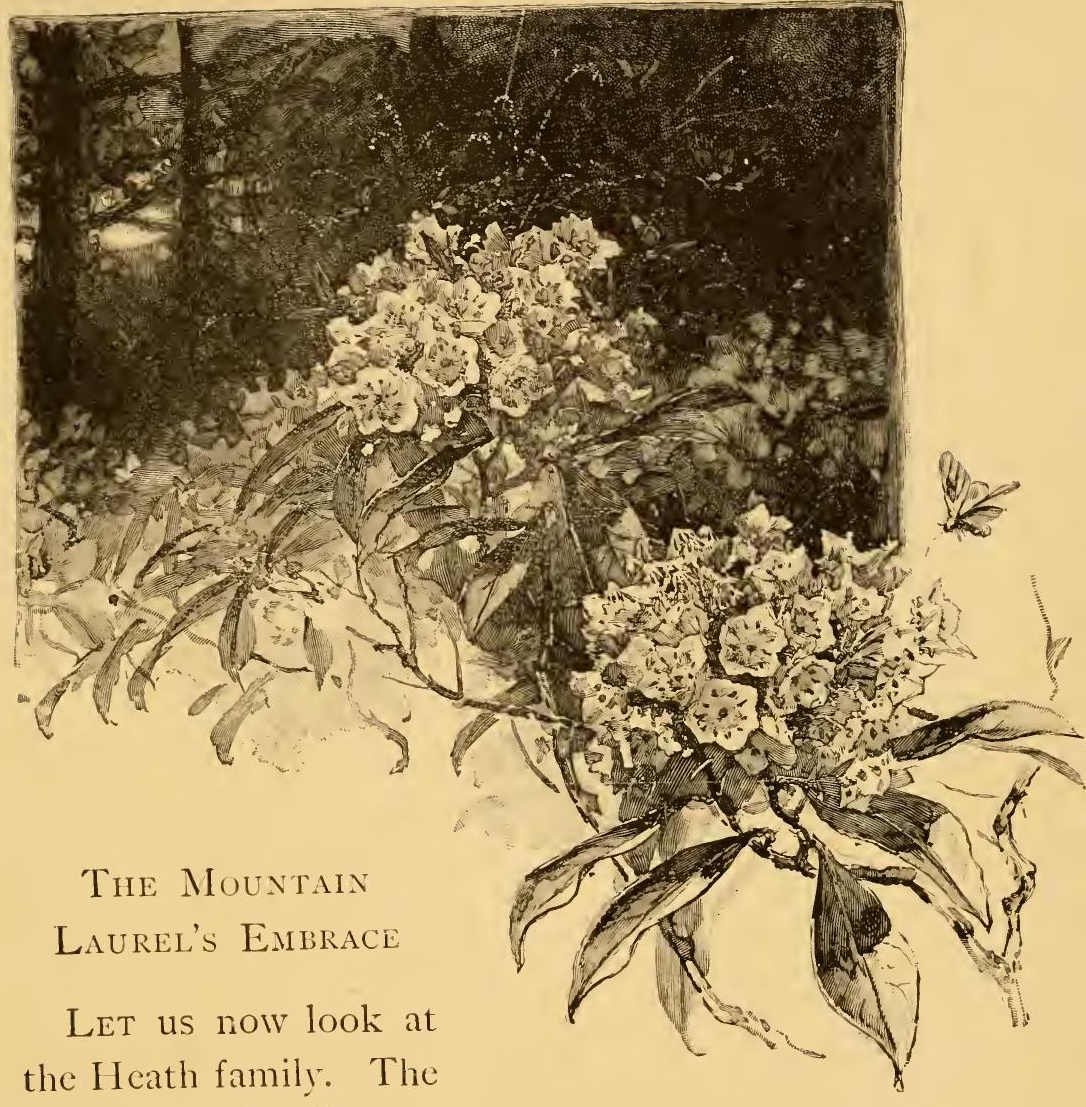

family of the heath, cran-

berry, pyrola, Androm-

eda, and mountain-laurel--how do these blossoms welcome their insect friends? This group is particularly distinguished by the unusual exception in the form of its anthers, which open by pores at their tips, instead of the ordinary side fissures. Two or 


\section{Blossom Hosts and Insect Gllests}

three forms of these anthers are shown in my row of stamens, page 25 .

Seen thus in their detached condition, how incomprehensible and grotesque do they appear! And yet, when viewed at home, in their bell-shaped corollas, their hospitable expression and greeting are seen to be quite as expressive and rational as those of other flowers. Take the mountain-laurel,
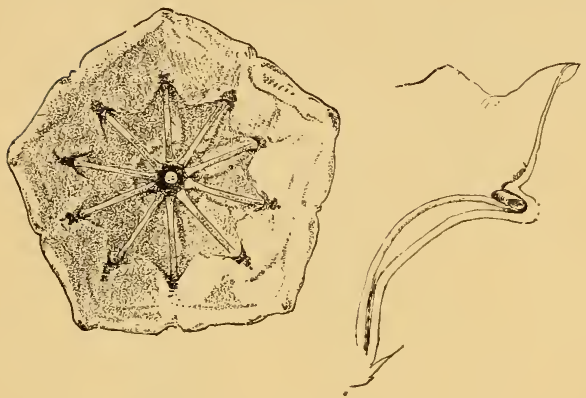

FIG. I. for irstance; what a singular exhibition is this which we may observe on any twilight crening in the laurel copse, the dense clusters of pink - white bloom waited upon by soft-winged fluttering moths, and ever and anon celebrating its cordial spirit by a mimic display of pyrotechnics as the anthers hurl aloft their tiny showers of pollen !

Every one is familiar with the curious construction of this flower, with its ten radiating stamens, each with its anther snugly tucked away in a pouch at the rim of its saucer-shaped corolla. Thus they appear in the freshly opened flower, and thus will they remain and wither if the flower is brought 


\section{The Mountain Lanrel's Embrace}

in-doors and placed in a vase upon our mantel. Why? Because the hope of the blossom's life is not fulfilled in these artificial conditions; its natural counterpart, the insect, has failed to respond to its summons.

But the twilight cluster in the woods may tell us a pretty story. Here a tiny moth hovers above the tempting chalice, and now settles upon it with eager

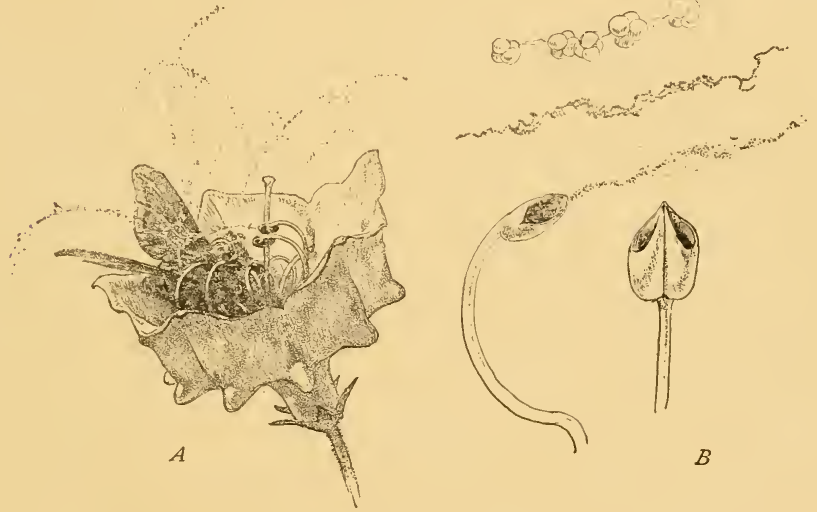

FIG. 2.

tongue extended for the nectar at its centre. What an immediate and expressive welcome! No sooner has this little feathery body touched the filaments than the eager anthers are released from their pockets, and, springing inward, clasp their little visitor, at the same time decorating him with their compliments of webby pollen, A, Fig. 2. 


\section{Blossom Hosts and Insect Gulests}

The nectary now drained of its sweets, the moth creeps or flutters to a second blossom, and its pollen-dusted body thus coming in contact with its stigma, cross-fertilization is accomplished. The pollen of the laurel differs from that of most of the Heath blooms, its grains being more or less adherent by a cobwebby connective which permeates the mass as indicated in my magnified representation, B, Fig. 2.

It is probable that an accessory cross-fertilization frequently results from a mass of the pollen falling directly upon the stigma of a neighboring bisssom, or even upon its own stigma; but even in the iatter case, as has been absolutely demonstrated as a general law by the experiments of Darwin, the pollen from a separate flower is almost invariably prepotent, and leads to the most perfect fruition, and thus to the survival of the fittest-the cross-fertilized. And, in any event, the insect is to be credited for the release of the tiny catapults by which the pollen is discharged.

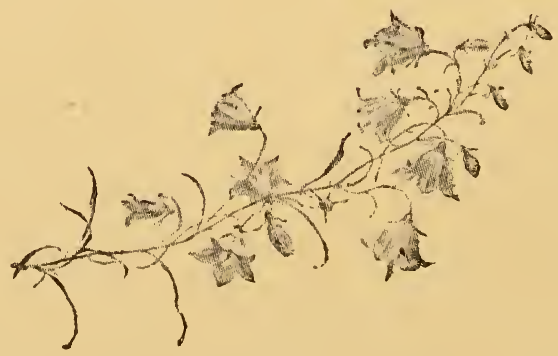




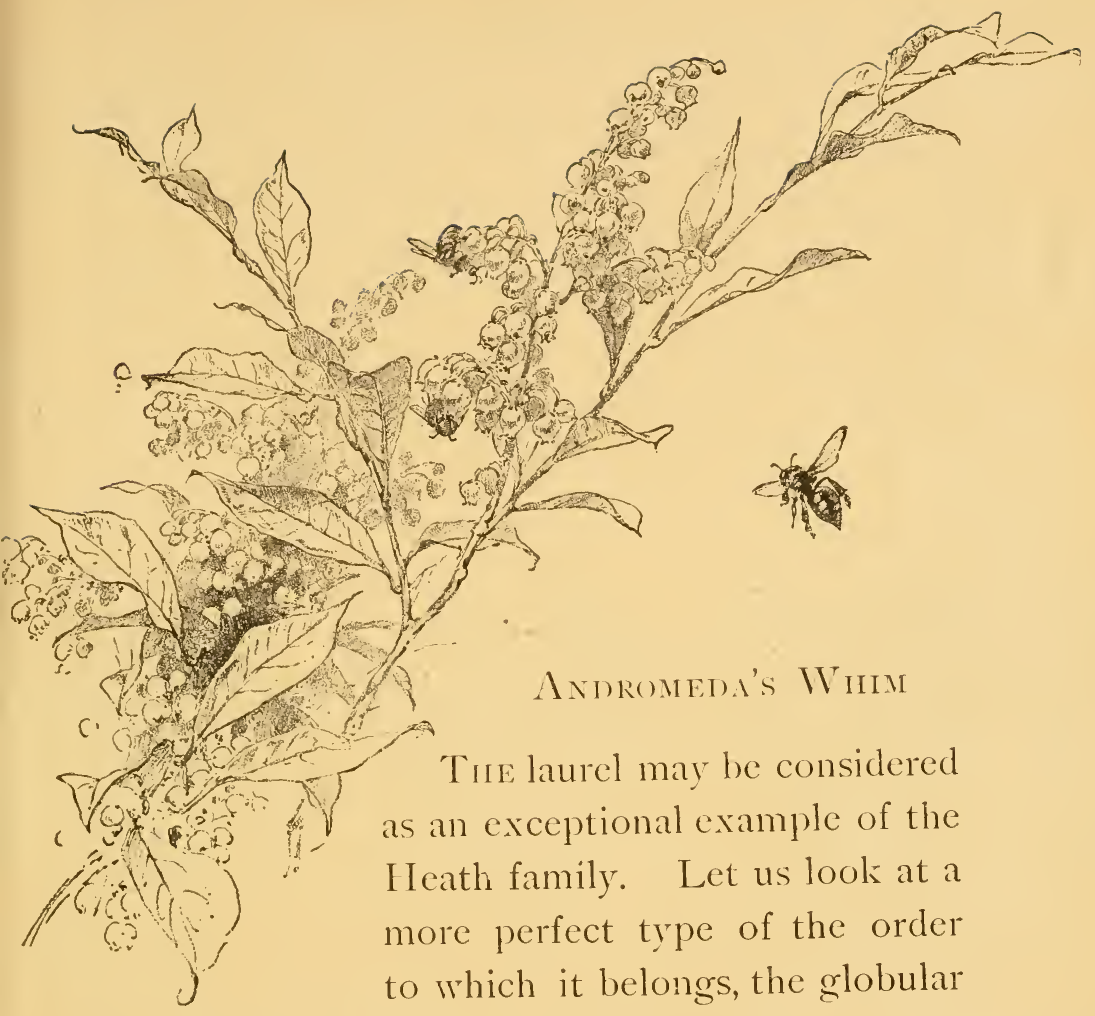

blossom of the Andromeda, A. ligustrina.

Only a short walk from my studio door in the country I recently observed its singular reception to the tiny black-and-white banded bee, which seems to be its especial companion, none the less constant and forgiving in spite of a hospitality which, from the human standpoint, would certainly seem rather discouraging. Fancy a morning call upon your particular friend. You knock at the 
door, and are immediately greeted at the threshold with a quart of sulphur thrown into your face. I this is precisely the experience of this patient little insect, which manifests no disposition to retaliate with the concealed weapon which on much less provocation he is quick to employ. Here he comes, eager for the fray. He alights upon one of the tiny bells scarce half the size of his body. Creeping down beneath it, he inserts his tongue into the narrowed opening. Instantly a copious shower of dust is poured down upon his face and body. But he has been used to it all his life, and by heredity he knows that this is Andromeda's peculiar whim, and is content to humor it for the sweet recompense which she bestows. The nectar drained, the insect, as dusty as a miller, visits another flower, but before he enters must of necessity first pay his toll of pollen to the drooping stigma which barely protrudes beneath the blossom's throat, and the expectant seed-pod above welcomes the good tidings with visions of fruition.

And how beautiful is the minute mechanical adaptation by which this end is accomplished! This species of Andromeda is a shrub of about four feet in height, its blossoms being borne in close panicled clusters at the summit of the 
branches. The individual flower is hardly more than an eighth of an inch in diameter. From one of three blossoms I made the accompanying series of three sectional drawings. The first shows the remarkable interior arrangement of the ten stamens surrounding the pistil. The second presents a sectional view of these stamens, showing their peculiar
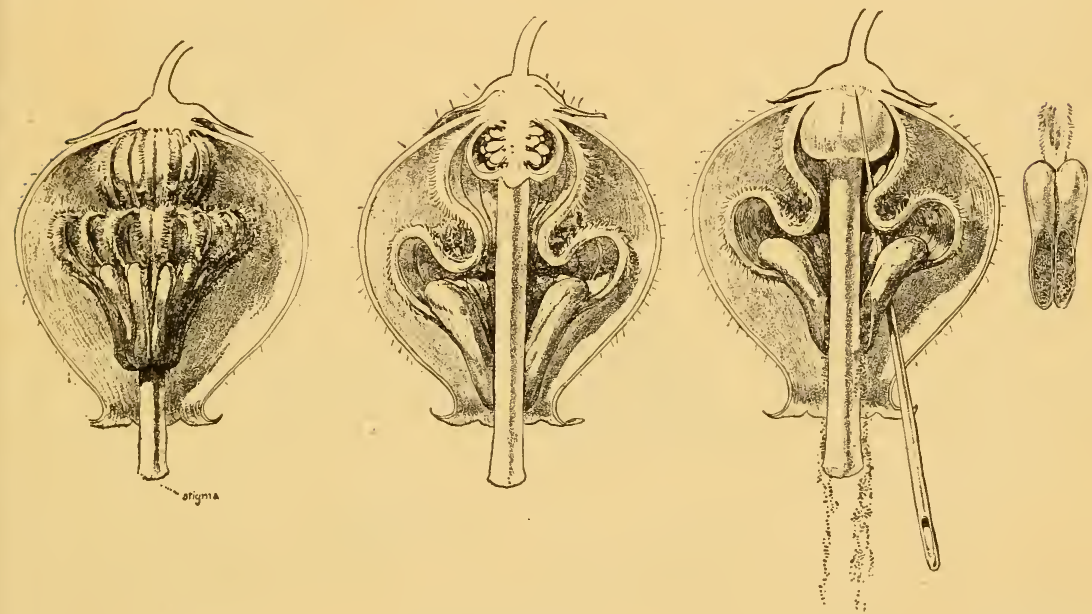

S-shaped filaments and ring of anthers-one of the latter being shown separate at the right with its two pores and exposed pollen. The freshly opened blossom discloses the entire ring of anthers in perfect equilibrium, each with its two orifices closed by close contact with the style, thus retaining the pollen. It will readily be seen that an insect's 
tongue, as indicated by the needle, in probing between them in search for nectar, must needs dislocate one or more of the anthers, and thus release their dusty contents, while the position of the stigma below is such as to escape all contact.

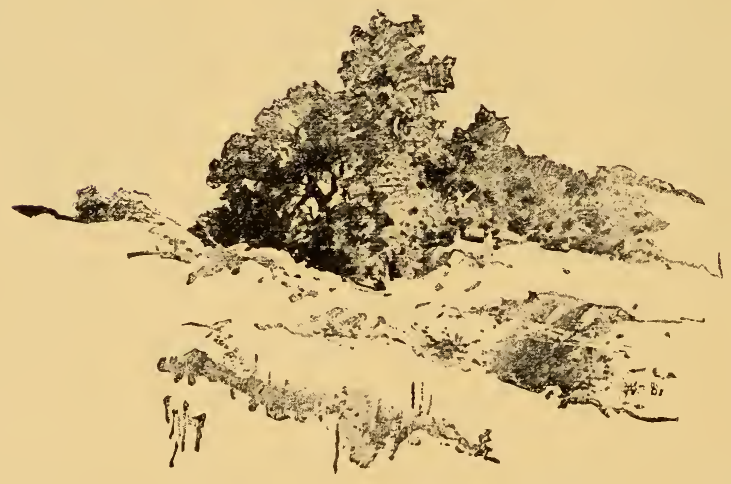




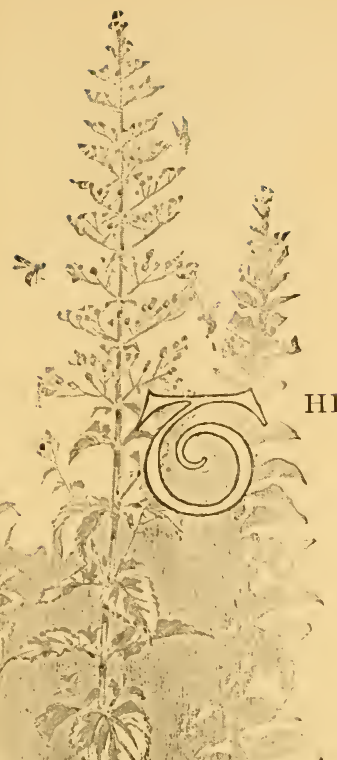

he Homely Figwort Attractive to Mistress Wasp

In my initial illustration is shown a sketch of the figwort, or Scrophularia, a tall, spindling, and apparently altogether uninteresting weed. It has rather fine, luxuriant leaves, it is true, but the tall, curiously branching spray of small. purplish-olive flowers is very insignificant. Though so ordinary in appearance, this weed has the honor of giving its name to its large and important family, other common members of which are the toadflax, butter-and-eggs, and foxglove. The figwort has not even a perfume, like the mignonette, to atone for its plainness; but it has an odor, if not a perfume, and it has a nectary 
which secretes the beads of swects for its pet companion insects, which in this instance do not happen to be bees or butterflies, but most generally wasps of various kinds, as these insects are not so particular as to the quality of their tipple as bees are apt to be. But the figwort has found out gradually through the ages that wasps are more serviceable in the cross-fertilization of its flowers than other insects, and it has thus gradually modified its shape, odor, and nectar especially to these insects.

Let us, then, take a careful look at these queer little homely flowers, and for the time being consider them as mere devices-first, to insure the visit of an insect, and, second, to make that insect the bearer of the pollen from one blossom to the stigma of another. Here we see a flower with three distinct welcomes on three successive days.

The flower-bud usually opens in the morning, and shows a face as at $\mathrm{A}$, which must be fully understood by looking at the side section shown at $A^{\text {r }}$. The anthers and pollen are not yet ripe, but the stigma is ready, and now guards the doorway. Tomorrow morning we shall see a new condition of things at that doorway, as seen at $B$ and $B^{r}$. The stigma has now bent down out of the way, while two anthers have unfolded on their stalks and now 


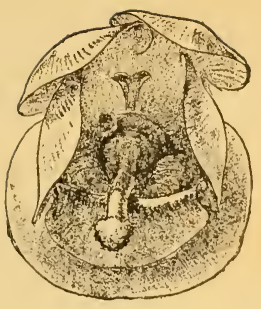

A. First Day's VTelcome. stigma at the Doorway.

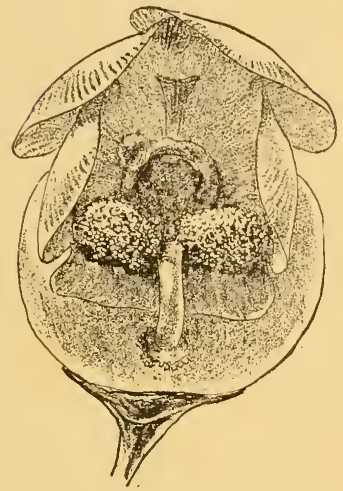

B. Second Day's Welcome. Stigma bent downward beneath two withered stamens at the Doorway.

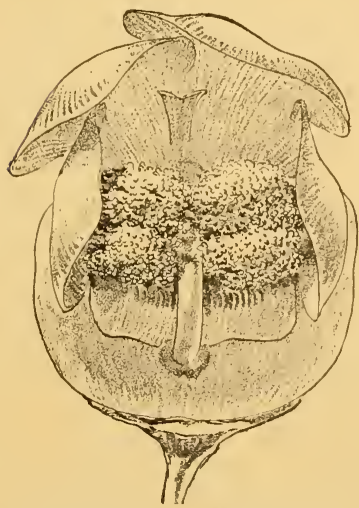

C. Third Day's Welcome. Four Stamens at the Doorway.

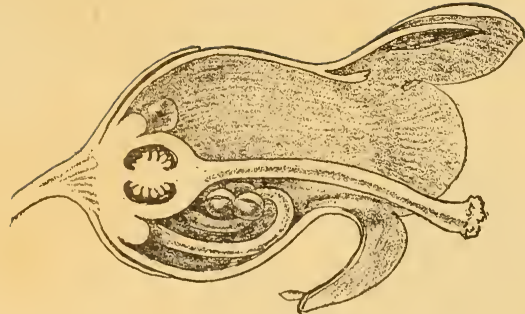

$\Lambda^{1}$. First Day. Sectional View.

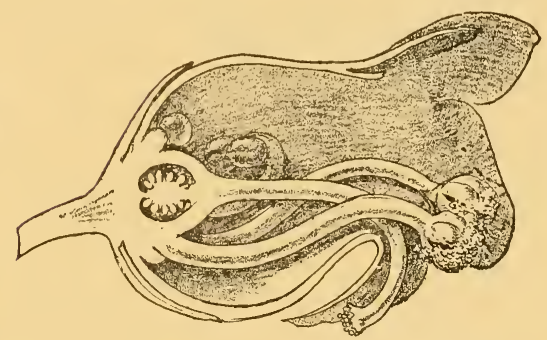

$B^{1}$. Second Day. Sectional View.
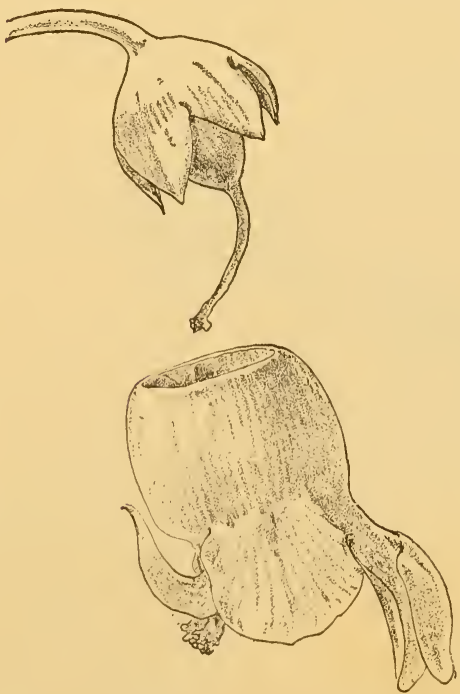

D. Fourth Day. Fall of Blossom. Its mission fulfilled. 
shed their pollen at the threshold. The third morning, or perhaps even sooner, the other pair come forward, and we see the opening of the blossom as at $\mathrm{C}$. Blossoms in all these three conditions are to be found on this cluster.

A small wasp is now seen hovering about the flowers, and we must turn our atten-

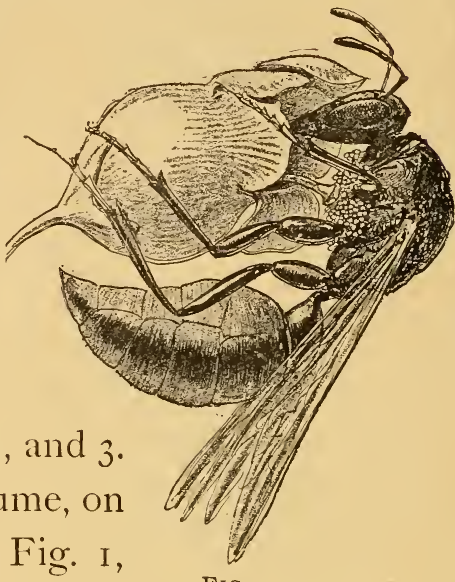

FIG. I. clinging with all his feet, and thrusttion to him as seen in Figs. I, 2, and 3 . The insect alights, we will assume, on a blossom of the second day, Fig. I, ing his tongue into the beads of nectar shown at $A^{x}$

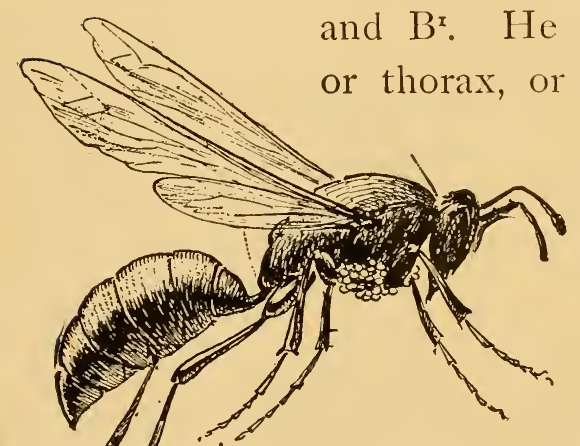
and $B^{x}$. He now brings his breast or thorax, or perhaps the underside of his head, against the pollen, and is thoroughly dusted with it. Leaving the blossom, we see him in flight, as at Fig. 2, and very soon he is seen to come to a freshly opened flower, FIG. 2. which he sips as before. The pollen is thus pushed against the projecting stigma, as 
The Homely Figwort Attractive to Mistress Wasp

shown at Fig. 3 , and thus, one by one, the flowers are cross-fertilized.

The stigma, after receiving pollen, immediately bends downward and backward, as shown in $\mathrm{B}^{\mathrm{r}}$, to give place to the ripening anthers, and shortly after the last pair of them have shed their pollen, the blossom, having then fulfilled its functions, falls off, as shown at D. This may be on the afternoon of the third day, or

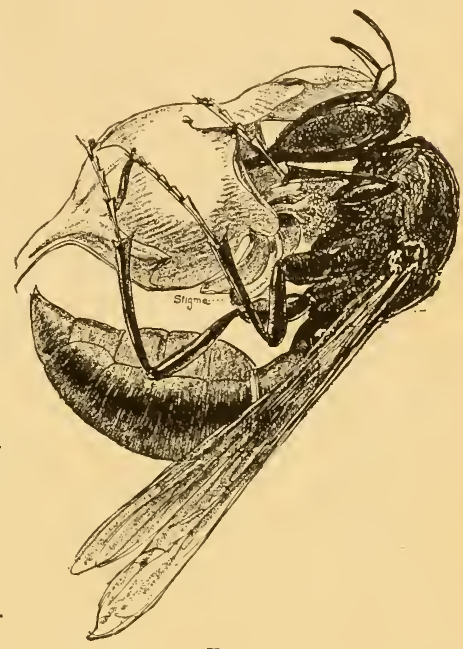

FIG. 3 .

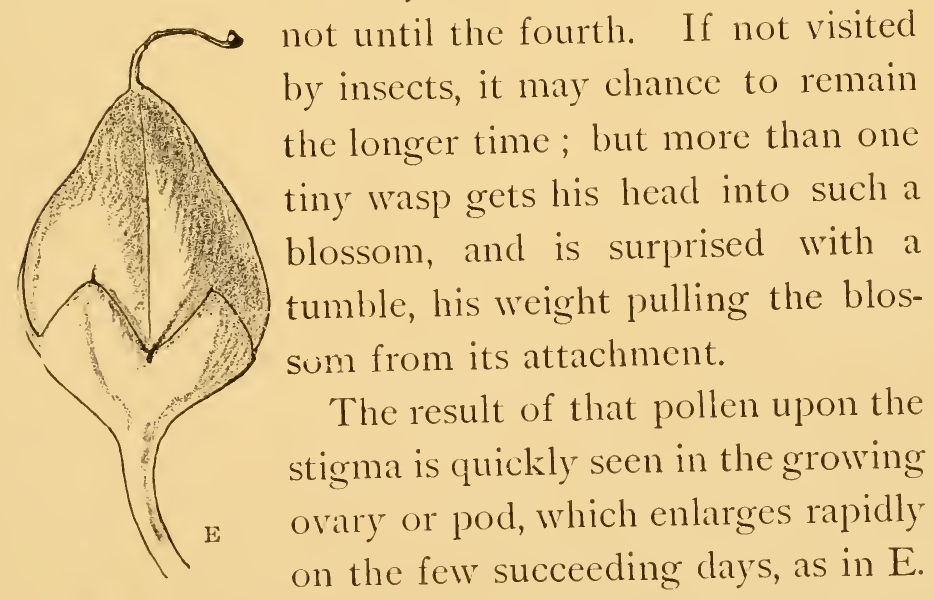
Many species of hornets and wasps, large and 


\section{Blossom Hosts and Insect Gulests}

small, are to be seen about the figwort blooms, occasionally bees, frequently bumblebees, which usually carry away the pollen on the underside of their heads. Who shall any longer refer to the figwort as an "uninteresting weed"?

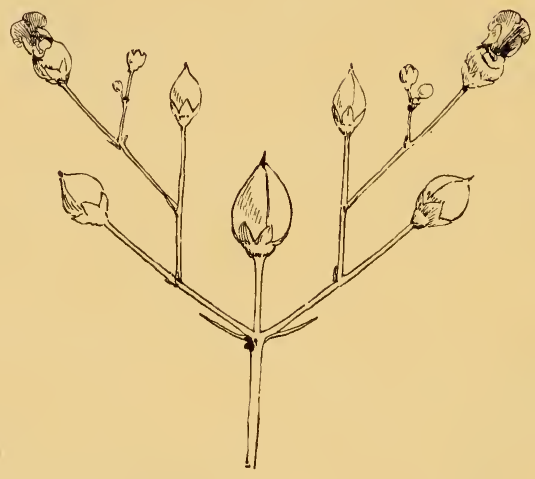




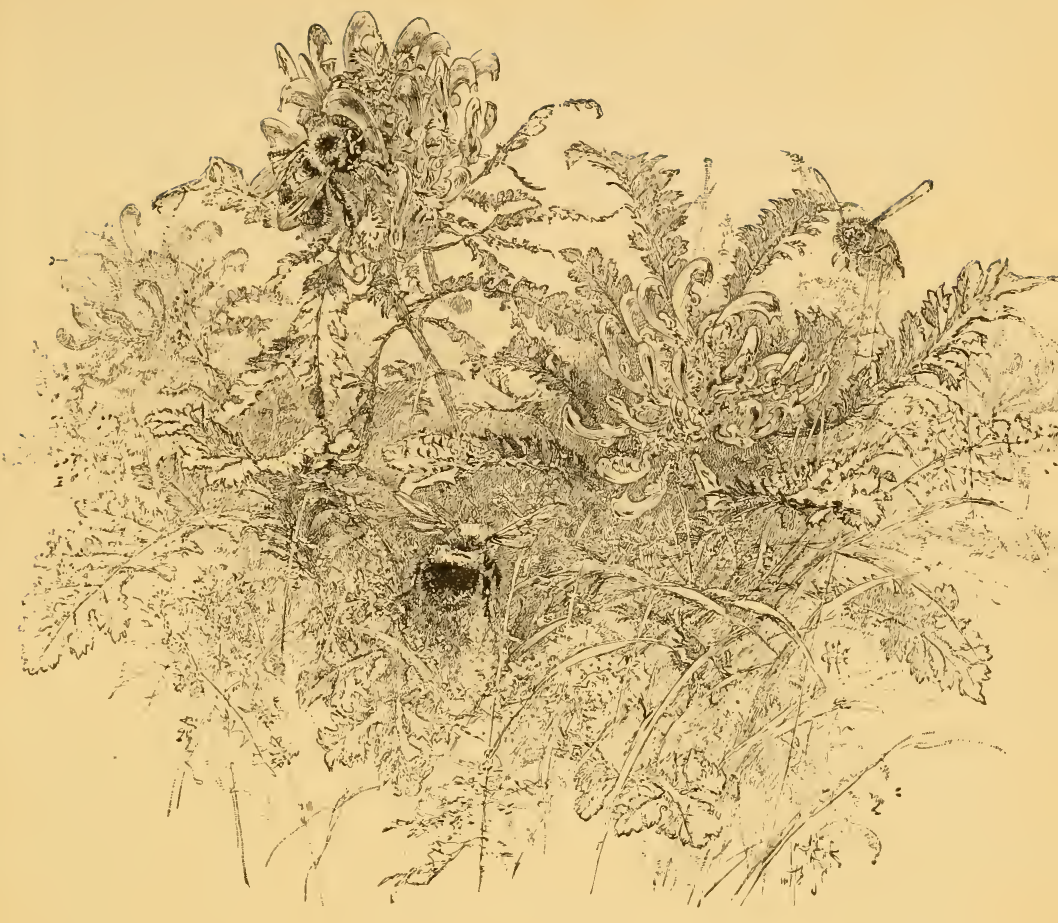

The Wood-Betony, a Protégé of the Bumblebef

Even here at our elbow in the woods is a plant which we have all known since childhood. The wood-betony, it is called-to select its worthier title, Pedicularia Canadonsis - a common early flower of our woods, closely allied to the figwort, and blooming in company with the uvularia, Solomon's-seal, crane's-bill, downy yellow violet, and 


\section{Blossom Hosts and Insect Gulests}

others. The plants grow in fern-like tufts, with scattered blossom heads of varied shades of yellow, pink, or even carmine.

I remember reading, a few years since, a remark by a prominent botanical authority concerning this flower, observing that its fertilization was a puzzle, as insects were rarely to be found upon it, which observation, taken together with what I had observed of the strange form and disposition of the blossoms, and the curiosity awakened by my reading, possessed a peculiar significance for me.

In the light of Darwin's and Müller's pages, how eagerly I now sought the haunt of my wood-betony, and how readily, too, it disclosed the secret which had heretofore escaped me as well as other earnest though too hasty seekers! Visiting a certain wood path, where the plants grew in profusion, I seated myself among them, and observed carefully. It was in the middle of May, and the flowers were in their prime, and in such omnipresent profusion that I felt assured some honey-seeking insect must soon be tempted thither among the tens of thousands of brimful nectaries.

I had not long to wait before a well-known "drowsy hum" fell upon my ear, and a large bumblebee alighted upon a flower-head close by. 


\section{The Wood-Betony, a Protege of the Bumblebee}

In his habitual impetuous fashion, he rifled the siweets from one and another of the blossom-heads, so lost in his absorbing work that I was permitted to steal close upon him and observe his eager method, for method, indeed, there was in every movement. In almost every instance he made his approach to the base of the flower-head, and followed around the spiral arrangement of the flowers to the summit of the cluster.

It needed only a single glance to receive an instant revelation of the reason which lay beneath this singular and always heretofore mysterious spiral arrangement of the flowers - their spiral arrangement not only, but the individual lateral curve of each separate blossom, which in every case brought the opening of its tube facing to the left. A moment's careful attention to my burly little interpreter revealed also the strange utility of the singular fissure down the right side of each corolla-a slit in the flower-tube extending from its throat half way to the base of the tube, but only on one side. Why on one side and not on the other? Why always on this outer curve of the flower? These had been questions which I had frequently asked myself when examining this queer, one-sided formation. But they were now answered to my satisfaction. 


\section{Blossom Hosts and Insect Guests}

The whole arrangement of these flowers, together with their individual tendencies, show a direct, conscious affiliation to the bumblebee, affording as perfect an illustration of the sympathetic dependence between flower and insect as we may find among the wonders of the orchid tribe so beautifully and clearly disclosed by Darwin.

What is this peculiar spiral progression, if not an inducement of convenience-an inviting flight of stairs, as it were? What is this individual turning about of each separate flower, if not a welcome invitation to its heart? and what is this strange fissure at the side but a facility to aid and to "speed the parting guest"? And through all this, how beautifully, by what wondrous art, has his mission been fulfilled! Observe our bee closely with me. He now alights obliquely at the base of a flower-head, inserts his head deep within the tube of the lowest flower, the strange fissure assisting in the expansion of its tube while his long tongue probes its nectary. His wedge-shaped head has forced apart the compressed sides of the corolla, thus opening the pollen-box (the compressed anthers) within the walls of the arched tip of the flower, the yellow fertilizing powder falling upon his head. 


\section{The Wood-Betonl', a Protege of the Bumblebee}

He has now emptied the horn of plenty, when, almost without withdrawing his head, he slips his tongue through the ready exit-the fissure in the flower-tube-to find an expectant, inviting face turned toward him, and in the most convenient possible attitude for his kiss.

He proceeds as before, hut not until he has unwittingly paid his toll and won his right of way, having deposited the requisite touch of pollen upon the overhanging tip of the stigma, and thus crossfertilized the flower. And thus he pursues his course to the summit of the spiral, carrying from its latest anthers a vivifying touch which secures in the next flower-head he visits the still more important function of absolute cross-fertilization from a separate plant. Indeed, it is doubtful whether the pollen from separate heads is not more or less continually intermingled, and this end secured in all the flowers, considering that only a grain or two of the thousands are required to insure the fertilization of the ovules.

Within an hour after the discovery of the first bee upon the wood-betony, the woods were murmuring with their mingled hum. I counted twenty of the insects at work within a radius of ten feet, and wondered that I could previously have been so blind 


\section{Blossom Hosts and Insect Guests}

to this marvellous drama which the winged actors of wayside and thicket had been enacting every day from April to June for centuries past.

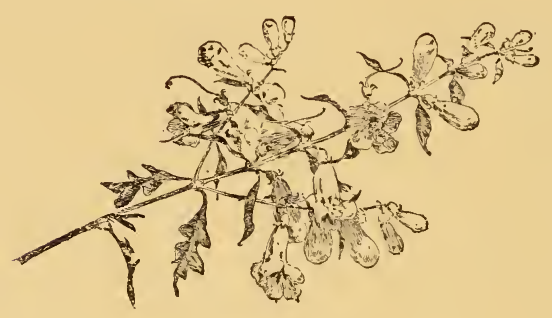




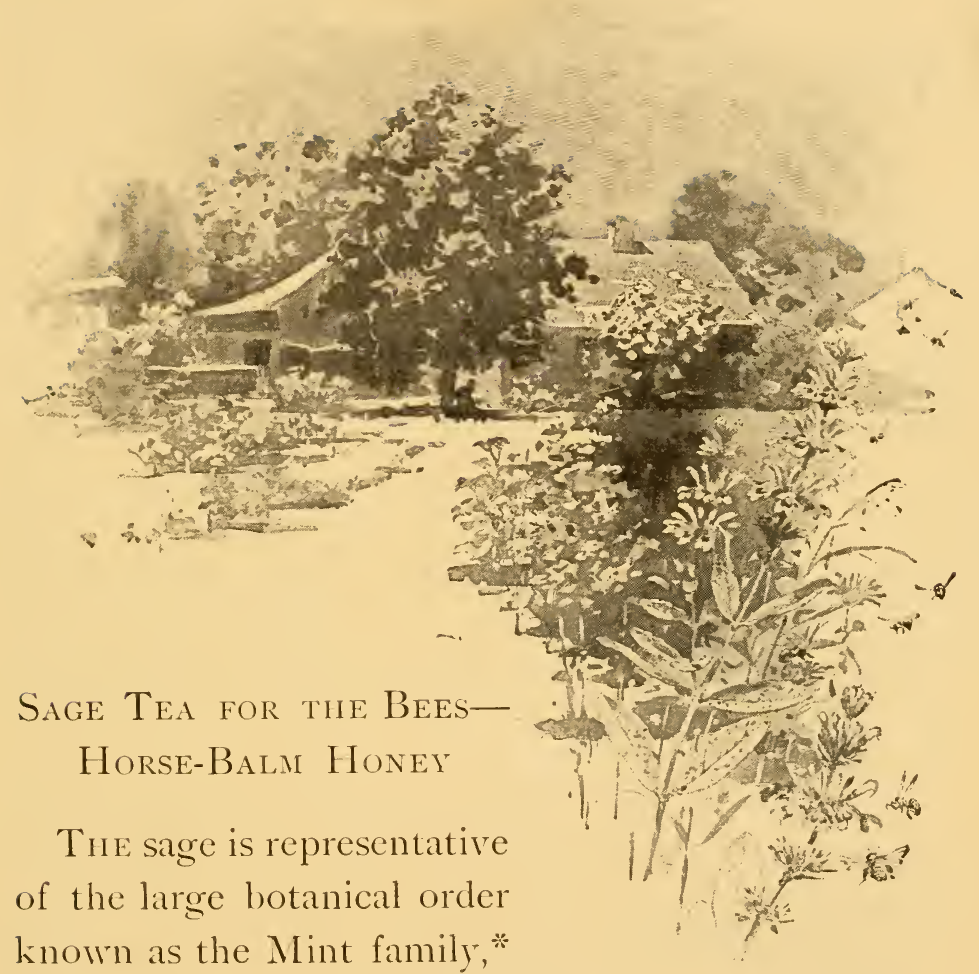
the labiates, or gaping, twolipped flowers, the arched hood here answering to the upper lip, the spreading base forming the lower lip, which is usually designed as a convenient

* Nearly all our savory herbs belong to this family-thyme, savory, rosemary, spearmint, hyssop, pennyroyal, lavender, etc. 


\section{Blossom Hosts and Insect Gulests}

threshold for the insects while sipping the nectar deep within the tube.

Every one is familiar with this old-fashioned favorite of the country garden, its lavender flowers arranged in whorls in a long cluster at the tip of the stem. One of these flowers, a young one from the top of the cluster, is shown at A, Fig. I, in section, the long, thread-like pistil starting from the ovary, and curving upward beneath the arch of the flower, with its forked stigma barely protruding (B). There are two of the queer stamens, one on each side of the opening of the blossom, and situated as shown, their anthers concealed in the hood above, and only their lower extremity appears below, the minute growth near it being one of the rudiments of two former stamens which have become aborted.

If we take a flower from the lower portion of the cluster (D), we find that the thread-like pistil has been elongated nearly a third of an inch, its forked stigma now hanging directly at the threshold of the flower. The object of this will be clearly demonstrated if we closely observe a bee upon the blossoms. Let us suppose he has reached the top of the cluster among the younger blossoms. $\mathrm{He}$ creeps up the outstretched platform of the flower, 


\section{Sage Tea for the Bees}

and has barely thrust his head within its tube when down comes the pair of clappers on his back (C). Presently he backs out, bearing a generous dab of yellow pollen, which is further increased from each subsequent flower. He has now finished this cluster, and flies to the next, alighting as usual on the lowermost tier of bloom. In them the elongated stigma now hangs $B$ directly in his path, and comes in contact with the pollen on his

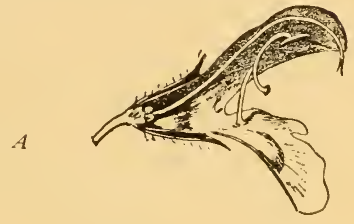
back as the insect sips the nectar. Cross-fertilization is thus insured, $c$ and, moreover, cross-fertilization not only from a distinct flower, but from a separate cluster, or

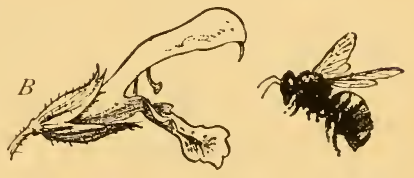
even a separate plant; for in these older stigmatic flowers the anther, as it comes down upon his back, is seen to be withered, having shed its pollen several days

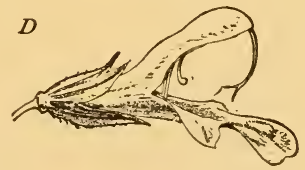

FIG. I. since, the supply of pollen on the bee's body being sufficient to fertilize all the stigmas in the cluster, until a new supply is obtained from the pollen-bearing blossoms above. And thus he continues his rounds. 
HORSE-BALM HONEY

Only a few days since, while out on a drive, I passed a luxuriant clump of the plant known as "horse-balm." I had known it all my life, and twenty years previously had made a careful analytical drawing of the mere botanical specimen. What could it say to me now in my more questioning mood? Its queer little yellow-fringed flowers hung
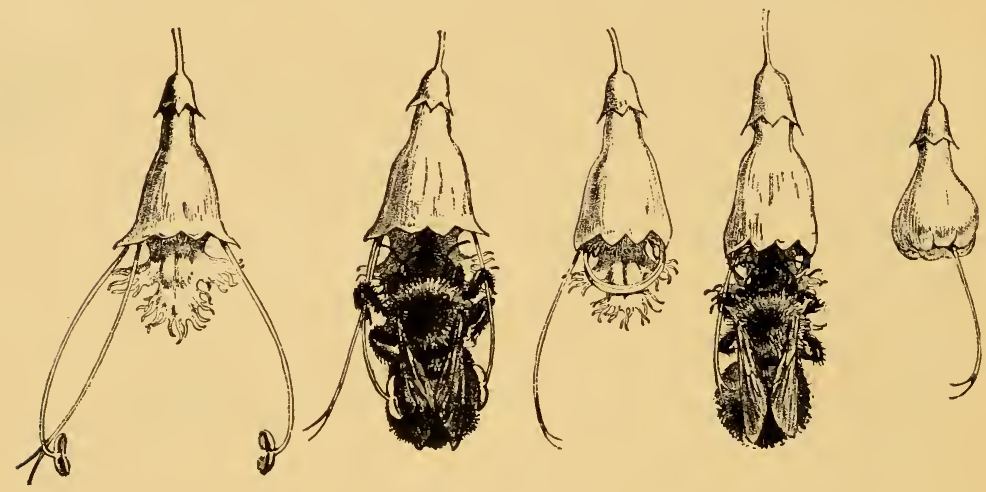

FIG. 2.

in profusion from their spreading terminal racemes. I recalled their singular shape and the two outstretched stamens protruding from their gaping corolla, and could distinctly see them as I sat in the carriage. I had never chanced to read of this flower in the literature of cross-fertilization, and murmuring, half aloud, "What pretty mystery is yours, my Collinsonia?" prepared to investigate. 


\section{Sage Ten for the Bees}

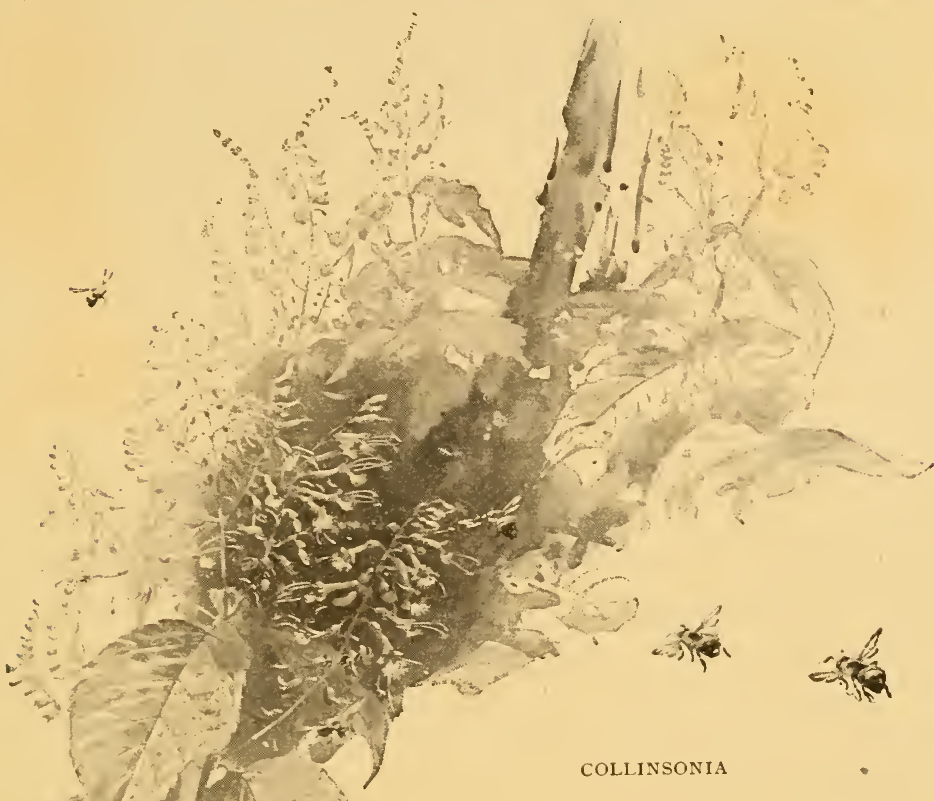

What I observed is pictured severally at Fig. 2, the flowers, with their two spreading stamens and the decidedly exceptional and unsymmetrical position of the long style extending to the side, being shown from above. A small nectar-seeking bumblebee had approached, and in alighting upon the fringed platform grasped the filaments for 
support, and thus clapped the pollen against his sides. Reasoning from analogy, it would of course be absolutely clear that this pollen has thus been deposited where it will come in contact with the stigma of another flower. So, of course, it proved. In the bee's continual visits to the several flowers, he came at length to the younger blooms, where the forked stigmas were turned directly to the front, while the immature stamens were still curled up in the flower tubes. Even the unopened buds showed a number of species where the early matured stigma actually protruded through a tiny orifice in precisely the right position to strike the pollen-dusted body of the bee, as he forced his tongue through the tiny aperture.*

* In numerous instances observed since the above was written, I have noted the larger bumblebees upon the blossom. ' These insects have a different method of approach, hanging beneath the flower, the anthers being clapped against their thorax at the juncture of the wings instead of the abdomen, as in the smaller bee.

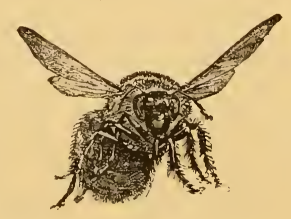




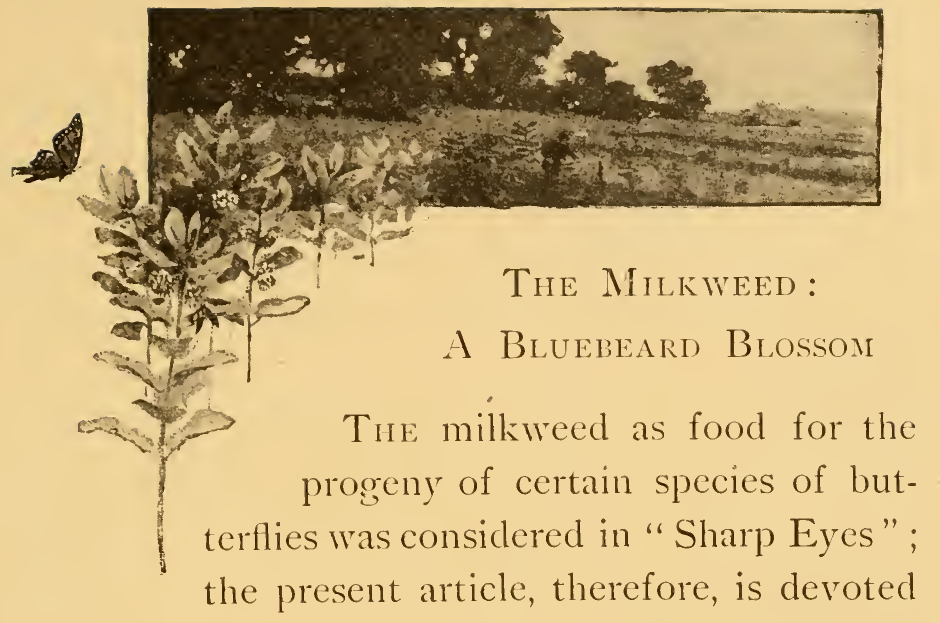

to the singular hospitality which its blossoms extend to the bee, a hospitality which is nowhere matched among Flora's minions, and would seem occasionally in need of supervision.

Just outside the door here at my country studio, . almost in touch of its threshold, year after year there blooms a large clump of the common milkweed. Acclcpias cormuta, and, what with the fragrance of its purple pompons and the murmurous music of its bees, its fortnight of bloom is not permitted to be forgotten for an instant. Only a moment ago a whiff of more than usual redolence from the open window at which I am sitting reminded me that the flowers were even now in the heyday of their prime, and the loud droning music betokened that the bees were making the most of their opportunities. 
Yielding to the temptation, I was soon standing in the midst of the plants. The purple fragrant umbels of bloom hung close about me on all sides, each flower, with its five generous horns of plenty, drained over and over again by the eager sipping swarm.

But the July sun is one thing to a bee and quite another thing to me. I have lingered long enough, however, to witness again the beautiful reciprocity, and to realize anew, with awe and reverence, how divinely well the milkweed and the bee understand each other. After a brief search among the blossom clusters, I return to my seclusion with a few interesting specimens, which may serve as a text here at my desk by the open window.

Two months hence occasional silky messengers will float away from the glistening clouds about the open milkweed pods, but whoever thanks the bees of June for them? The flower is but a bright anticipation-an expression of hope in the being of the parent plant. It has but one mission. All its fragrance, all its nectar, all its beauty of form and hue are but means toward the consummation of the eternal edict of creation-" increase and multiply." To that end we owe all the infinite forms, designs, tints, decorations, perfumes, mechanisms, 


\section{The Milkweed: A Bluebeard Blossom}

and other seemingly inexplicable attributes. Its threshold must bear its own peculiar welcome to its insect, or perhaps to its humming-bird friend, or counterpart; its nectaries must both tempt and rcward his coming, and its petals assist his comfortable tarrying.

Next to the floral orchids, the mechanism of our milkweed blossom is, perhaps, the most complex and remarkable, and illustrates as perfectly as any of the orchid examples given in Darwin's noble work the absolute divine intention of the dependence of a plant species upon the visits of an insect.

Our milkweed flower is a deeply planned contrivance to insure such an end. It fills the air with enticing fragrance. Its nectaries are stored with sweets, and I fancy each opening bud keenly alert with conscious solicitude for its affinity. Though many other flowers manage imperfectly to perpetuate their kind in the default of insect intervention, the milkweed, like most of the orchids, is helpless and incapable of such resource. Enclose this budded umbel in tarlatan gauze and it will bloom days after its fellow-blooms have fallen, anticipating its consummation, but no pods will be seen upon this cluster.

What a singular decree has Nature declared with 


\section{Blossom Hosts and Insect Guests}

reference to the milkweed! She says, in plainest terms, "Your pollen must be removed on the leg of an insect, preferably a bee, or your kind shall perish from the face of the earth." And what is the deep-laid plan by which this end is assured? My specimens here on the desk will disclose it all. Here are two bees, a fly, and a beetle, each hanging dead by its legs from a flower, an extreme sacrificial penalty, which is singularly frequent, but which was certainly not exacted nor contemplated in the design of the flower. A careful search among almost any good-sized cluster of milkweeds will show us many such prisoners. As in all flowers, the pollen of the milkweed blossom must come in contact with its stigma before fruition is possible. In this peculiar family of plants, however, the pollen is distinct in character, and closely suggests the orchids in its consistency and disposition. The yellow powdery substance with which we are all familiar in ordinary flowers is here absent, the pollen being collected in two club-shaped or, more properly, spatula-shaped masses, linked in pairs at their slender prolonged tips, each of which terminates in a sticky disk-shaped appendage united in $\mathrm{V}$-shape below. These pollen masses are concealed in pockets (B) around the cylindrical centre of the 


\section{The Milkwed: A Blllebeard Blossom}

flower, the disks only being exposed at the surface, at five equidistant points around its rim, where they lie in wait for the first unwary foot that shall touch them.

A glance at the two views of this central portion of the flower, as it appears through my magnifying-
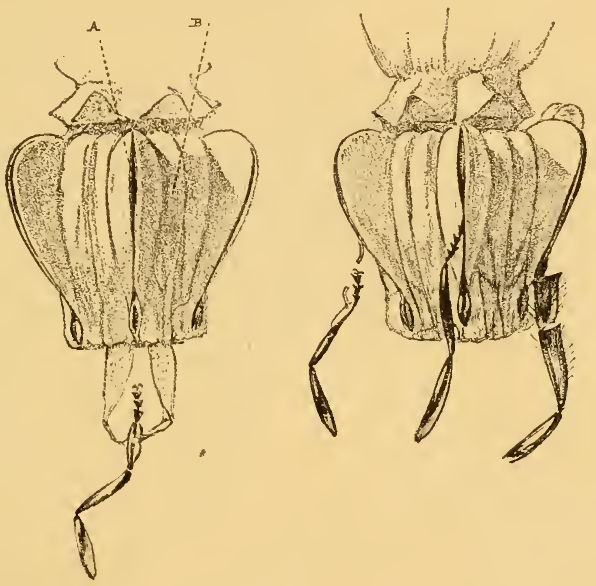

glass-the honey-horns and sepals having been removed-will, I think, indicate its peculiar anatomy or mechanism. No stigma is to be seen in the flower, the stigmatic surface which is to receive the pollen being concealed within five compartments, each of which is protected by a raised, tentlike covering, cleft along its entire apex by a fine fissure (A). Outside of cach of these and cntircly 


\section{Blossom Hosts and Insect Guests}

separated from the stigma in the cavity lie the pollen masses within their pockets, each pair uniting at the rim below in $\mathrm{V}^{\top}$-shape, the union at the lower limit of the fissure.

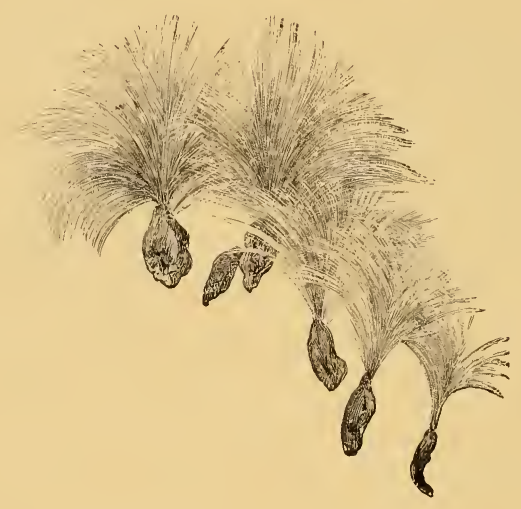


the base. The foot is thus conducted directly between the two viscid disks, which immediately cling closer than a brother, and as the foot is finally withdrawn, it brings with it the pollen which it has pulled from its cell. The bee now released seeks a fresh flower, and the same result follows, the leg almost inevitably entering the fissure, and this time drawing in the pollen directly against the sticky stigmatic surface within. When the five honeyhorns have been drained, and as our bee seeks to leave the flower, he is plainly detained by this too hearty "shake" or "grip" of his host, and quite often must exert a slight struggle to free himself. As the foot is thus forcibly torn away, the pollen mass is commonly scraped entirely off and retained within the fissure, or perhaps parts at the stalk, leaving the terminal disk clinging on the insect's leg. Óccasionally, when more than one leg is entangled, the dangling blossom is tossed and swayed for several seconds by the vigorous pulling and buzzing, and number of these temporary captives upon a single milkweed plant are always to be seen.

Not unfrequently the mechanism so well adapted exceeds its functions and proves a veritable trap, as indicated in my specimens. I have found three 


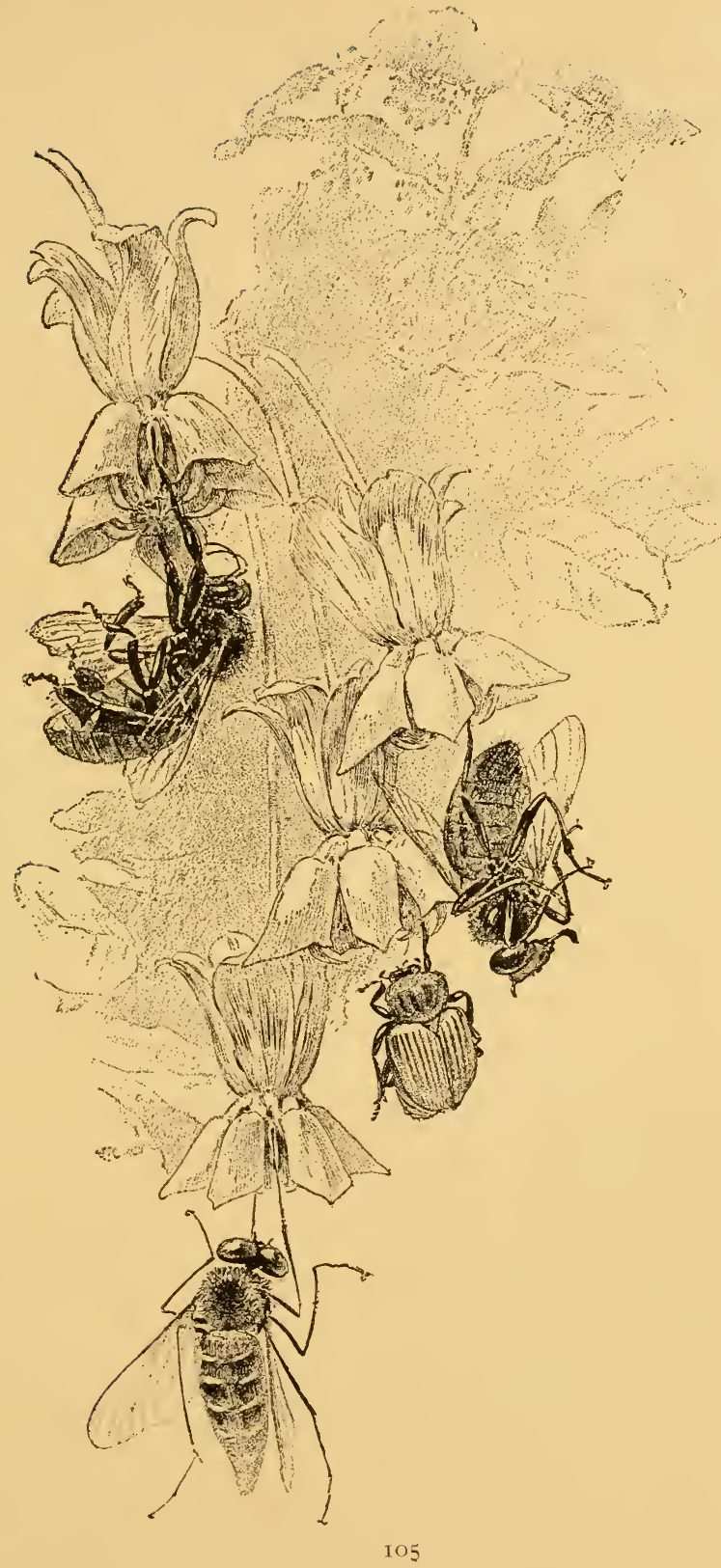




\section{Blossom Hosts and Insect Gulests}

dead bees thus entrapped in a single umbel of blossoms, having been exhausted in their struggles for escape; and a search among the flowers at any time will show the frequency of this fatality, the victims including gnats, flies, crane-flies, bugs, wasps, beetles, and small butterflies. In every instance this prisoner is found dangling by one or more legs, with the feet firmly held in the grip of the fissure.

Almost any bee which we may catch at random upon a milkweed gives perfect evidence of his surroundings, his toes being decorated with the tiny yellow tags, each successive flower giving and taking, exchanging compliments, as it were, with its fellows. Ordinarily this fringe can hardly prove more than an embarrassment; but we may frequently discern an individual here and there which for some reason has received more than his share of the milkweed's compliments. His legs are conspicuously fringed with the yellow tags. He rests with a discouraged air upon a neighboring leaf, while honey, and even wings, are seemingly forgotten in his efforts to scrape off the cumbersome handicap.

An interesting incident, apropos of our embarrassed bee, was narrated to me by the late Alphonso 


\section{Bluebeard's Methods}

Wood, the noted botanist. He had received by mail from California a small box containing a hundred or more dead bees, accompanied by a letter. The writer, an old bec-keeper, had experience, and desired enlightenment and advice. The letter stated that his bees were "dying by thousands from the attacks of a peculiar fungus." The ground around the hive was littered with the victims in all stages of helplessness, and the dead insects were found everywhere at greater distances scattered around his premises.

It needed only a casual glance at the encumbered insects to see the nature of the malady. They were laden two or three layers deep, as it were, with the pollen masses of the milkweed. The botanist wrote immediately to his anxious correspondent, informing him, and suggesting as a remedy the discovery and destruction of the mischievous plants, which must be thriving somewhere in his neighborhood. A subsequent letter conveyed the thanks of the beekeeper, stating that the milkweeds-a whole field of them-had been found and destroyed, and the trouble had immediately ceased.

I am not aware that Mr. Wood ever ascertained the particular species of milkweed in this case. It is not probable that our Eastern species 


\section{Blossom Hosts and Insect Guests}

need ever seriously threaten the apiary, though un. questionably large numbers of bees are annually destroyed by its excessive hospitality.

Allied to the milkweed is another plant, the dogbane, Apocynum, which has a similar trick of entrapping its insect friends. Its drooping, fragrant, bell-shaped white flowers and long slender pods will help to recall it. But its method of capture is somewhat similar to the milkweed. The anthers are divided by a $\mathrm{V}$-shaped cavity, into which the insect's tongue is guided as it is withdrawn from the flower, and into which it often becomes so tightly wedged as to render escape impossible. I have found small moths dangling by the tongue, as seen in the illustration below.

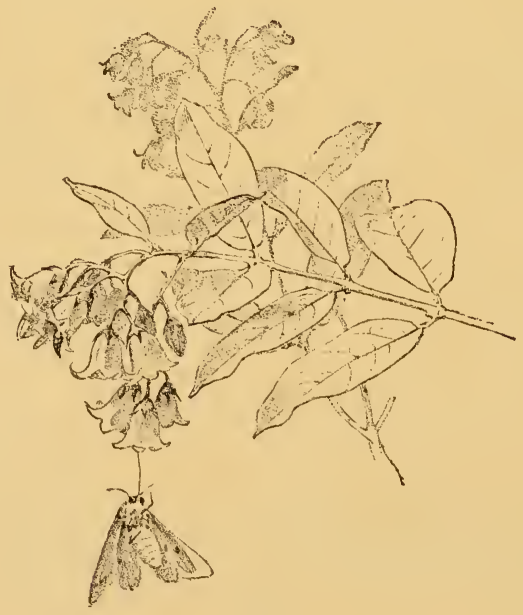




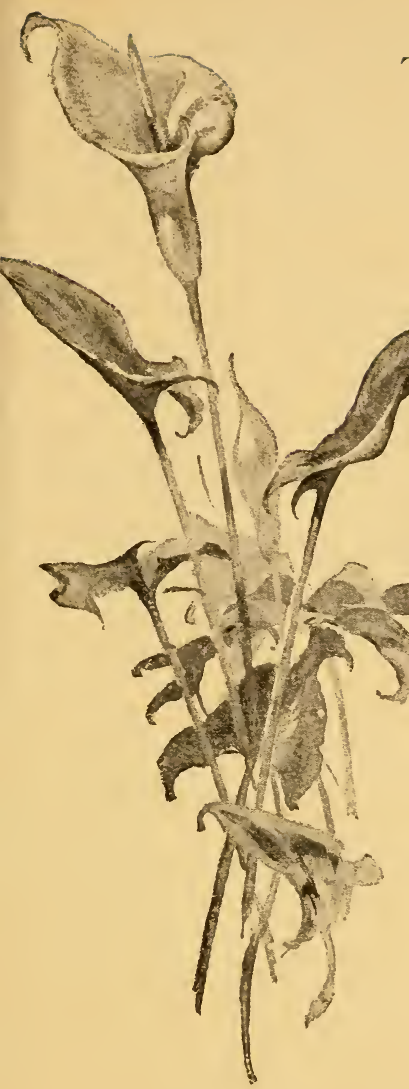

\section{TiIE LORds AND LADIES \\ OF THE \\ Arum Fanily}

The most remarkable member of the Arum family is a British subject. Its method of welcome and au revoir to insects is unique and truly astonishing. All of the flowers we have so far examined are more or less automatic in their movements, but the wild arum seems to display almost conscious mechanism.

A representation of this arum is shown in Fig. I, and a crosssection at $\mathrm{A}$, properly indexed.

How confidently would the superficial-nay, even careful-examination of one of the old-time botanists have interpreted its structure: "How simple and perfect the structure! Observe how the anthers are placed so that pollen shall naturally fall directly on the stigmas and fertilize them!" Such would indeed appear to be intended, until it is actually discovered that the 
stigmas have withered when the pollen is shed-a device which, acting in association with the little

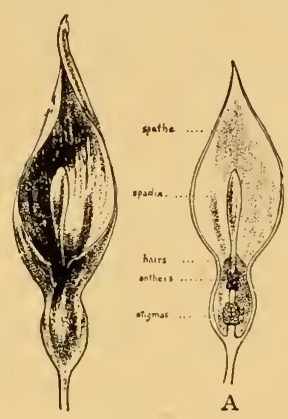

FIG. I, ring of hairs, tells a strange story. It is not my fortune to have seen one of these singular blossoms, but from the description of the process of fertilization given in Hermann Müller's wonderful work, aided by a botanical illustration of the structure of the flower, I am readily enabled to picture the progressive stages of the mechanism.

In the first stage (B, Fig. 2), small flies with bodies dusted with pollen from a previous arum blossom are entering the narrowed tube, easily passing through the drooping fringe of hairs. Nectar is secreted by the stigmas, and here the flies assemble, thus dusting them with pollen. Their appetite temporarily satisfied, the insects seek escape, but find their exit effectually barred by the intruding fringe of hairs $(\mathrm{C})$. In this second stage, the stigmas, having now been fertilized, have withered, at the same time exuding a fresh supply of nectar, which again attracts the flies, whereupon, as shown at $\mathrm{D}$, the anthers open and discharge their pollen upon the insects. In the fourth stage (E), 
all the functions of the flower having now been fulfilled, the fringe of hairs withers, and the imprisoned
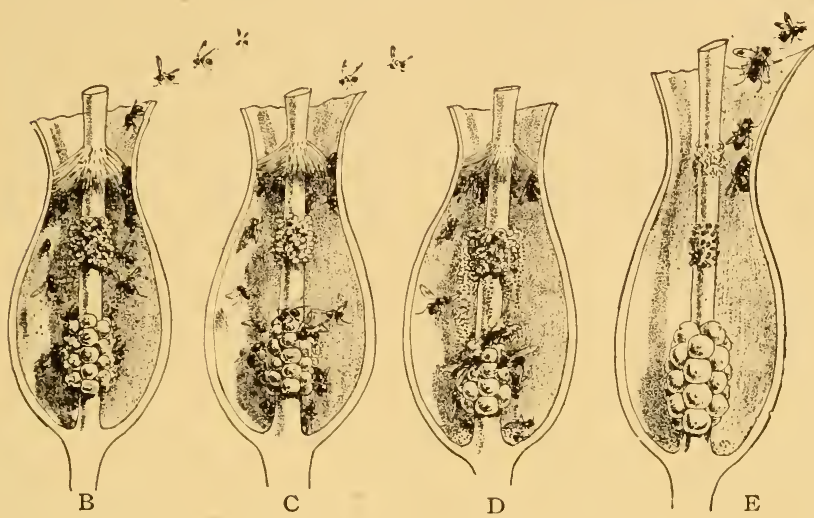

FIG, 2.

pollen-laden flies are permitted to escape to another flower, where the beautiful scheme is again enacted.

\section{J.ACK-IN-THE-PULPIT}

These "lords" and "ladies" of the village lanes are the foreign counterparts of our well-known Jack-in-the-pulpit, or Indian turnip, the sleek preacher of which stands so erect beneath his purple-streaked canopy.

Jack-in-the-pulpit, like the arum, has the streaked hood, and the "lords" and "ladies" dwell generally

* The arums with the purple-tinged hoods are called the "lords" and those with light green hoods the "ladies," because this difference in color was formerly thought to indicate the sex of the flower within. Later investigations, however, prove that while the purpletinged ones are more often "lords" than "ladies," they are not invariably "lords." 


\section{Blossom Hosts and Insect Gillests}

under separate canopies - that is, the stigmatic flowers and pistillate flowers are found in different blossoms. Jack stands, you will find, on a bulb which, in the pistillate flowers, is composed of small ovules, and, in the stigmatic flowers, is covered with thread-like filaments. As in the arum, the coloring of the hood is not an infallible guide to the sex of the flower.

Small fungus gnats visit these blossoms and are often imprisoned in their deep chambers, for, though entrance is easy, egress is difficult, the way being blocked by the projection of the spadix. Many insects escape from this prison cell through the folds of the floral envelope, but many others perish. It is thought that Jack-in-the-pulpit is in a transition state and that its plan to insure cross-fertilization is not yet perfected. This view is borne out by the fact that, although the intention of the plant is to separate its staminate and pistillate flowers, they are frequently found on the same spadix. When Jack has reached the ideal state which he aims at, his own and the insects' interests will be provided for in a better fashion.

THE HERMIT OF THE BOG

By far the humblest of all the arums is the skunkcabbage. This lowly hermit of the bog is the first 


\section{Blossom Hosts and Insect Gulests}

Observe, too, the throngs of flies and bees that hasten to visit its parlors. They long ago gave it a place in their posy, and though their taste may not accord with ours, their judgment cannot be disputed.

The stigmatic flowers mature on the skunk-cabbage's spadix before the pistillate ones. Like other blossoms with foul odors, this one is especially adapted for fertilization by scavenger flies. Though bees visit it, they probably do so because at the season when it blooms they have no choice of flowers, and not because it attracts them. Naturalized European bees are the chief visitors; and since our flora is not well adapted to them, they have to make many shifts, for a living, that cannot fail to be disagreeable. They often pay with their lives for their trespassing, for while the invited guests find no difficulty, the banquet finished, in leaving the blossom, the bee who has barely forced an entrance frequently fails to make good his escape through the narrow doorway, and either dies of starvation or falls a victim to the wise spiders who spread their catch-alls within these horns of plenty.

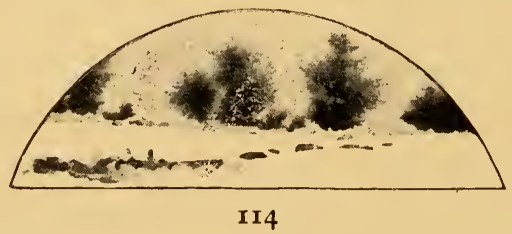




\section{The Swaying Iris}

"Born in the purple, born to joy and pleasance, Thou dost not toil nor spin,

But makest glad and radiant with thy presence The meadow and the lin."

WE have the good fortune to number among our native wild flowers the beautiful fleur-de-lis,

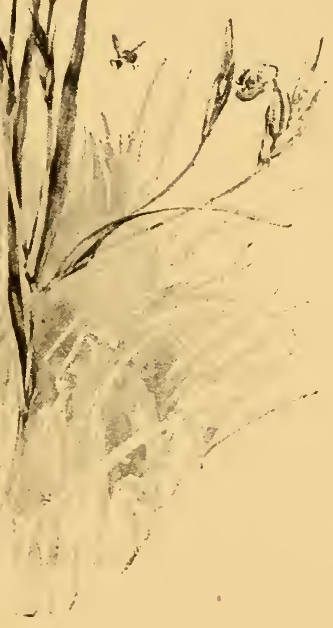
commonly called the blueflag, the blossom chosen by the kings of France for their emblem.

The graceful family to which this blossom belongs has been most appropriately named for the youthful goddess of the rainbow, the fair lady Iris. Our flower, however, is a goddess in another court than that of Olympus, and her courtiers, though winged folk, can lay no claim to the supernatural. It may well be doubted, however, that the goddess of the clouds, in all the glory of court dress and attendance, ever presented a prettier picture than a company of these earthly flowers, set in velvety 
moss, clothed in royal purple, and surrounded by groups of gayly attired, fluttering admirers.

The blue-flag is a conspicuous example of a flower which has guarded itself against self-fertilization and which is beautifully calculated to secure the opposite result.

In most flowers, with the exception of the orchids, the stamens and pollen are plainly visible; but who ever sees the anthers of the blue-flag? Surely none but the analytical botanist and the companion insect to whom it is so artfully adjusted and so demonstrative. This insect is likely to be either a bumblebee or a species of large fly.

In apt illustration of Sprengel's theory of the "pathfinder," the insect does not alight at the centre of the flower, but upon one of the three large drooping sepals, whose veins, converging to the narrow trough above, indicate the path to the nectar. Closely overarching this portion is a long and narrow curved roof-one of three divisions to the style, each surmounting its veined sepals. Beneath this our visiting bee disappears, and a glance at my sectional drawing shows what happens. Concealed within, against the ridge-pole, as it were, the anther awaits his coming, and in his passage to and from the nectar below spreads its pollen over his head and back. 
Having backed out of this segment of the blossom as shown at $A$, he proceeds to the next; but the shelf-like stigma awaits him at the door, and scrapes off or rubs off a few grains of the pollen from his back (B). Thus he continues until the third segment is reached, from which he carries away a fresh load of

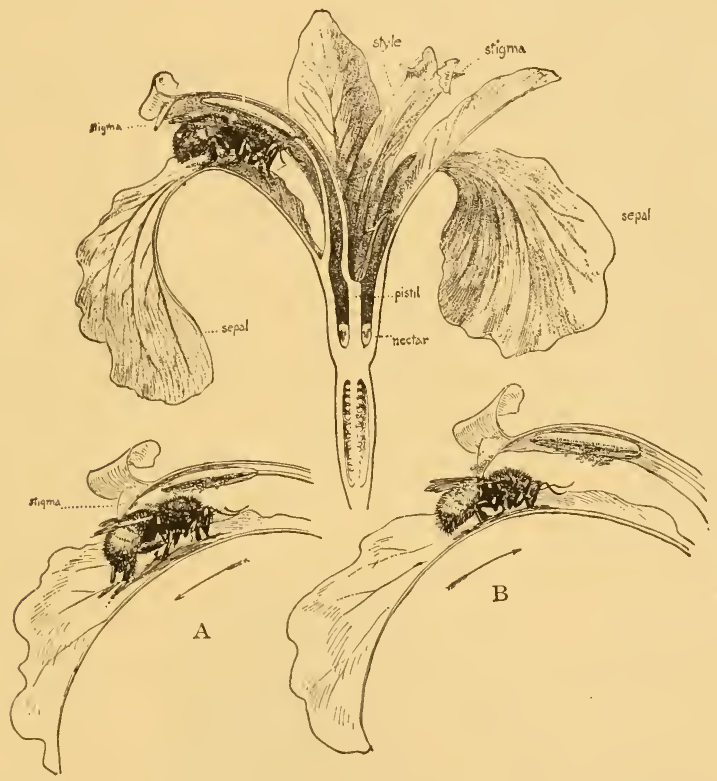

pollen to another flower. It will be seen that only the outer side of this appendage is stigmatic, and that it is thus naturally impossible for the blue-flag to self-fertilize-only one instance of thousands in which the anther and stigma, though placed in 


\section{Blossom Hosts and Insect Gulests}

the closest proximity, and apparently even in contact-seemingly with the design of self-fertilization - are actually more perfectly separated functionally than if in separate flowers, the insect alone consummating their affinity.

The blue-flag suffers constantly from the visits of pilferers, chiefly butterflies, which alight upon the drooping petals, and thrusting their long tongues through narrow openings between the lobes of the perianth, rifle the blossom of its sweets, without bestowing or receiving any pollen.

As the blue-flag grows in moist places, and consequently secretes an abundant supply of nectar, this robbery is not so serious a matter as it would be in the case of some other flowers.

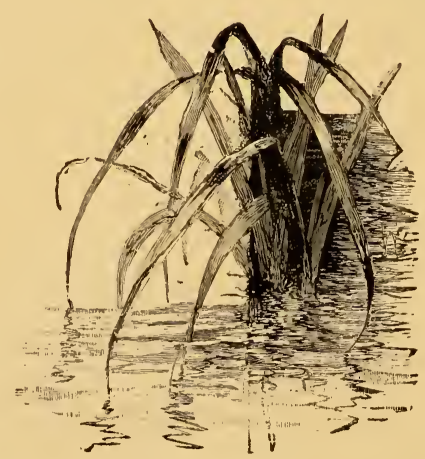




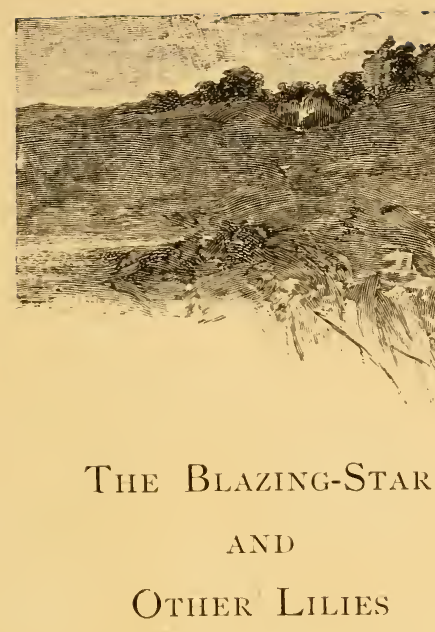

WE have seen how in some flowers self-fertilization is prevented by the stigmas and anthers maturing at different periods, as in the figwort and arum ; in others, as in the iris, milkweed, and many composita, by mere mechanical means, and in the bluets by the production of two forms of flowers.

A pretty illustration of the method which places the stigmatic flowers in different blossoms from the pollen-producing stamens (the method which Jack-in-the-pulpit is endeavoring to perfect) is to be seen in the little wild flower known as the devil's-bit, Chamalivium lutcum, a true lily. 


\section{Blossom Hosts and Insect Gulests}

Its long, white, tapering spire of feathery bloom may often be seen rising abore the sedges in the swamp. Two years ago I chanced upon a little colony of four or five plants at the edge of a bog. The flowers, all of them, were mere petals and stamens (like B of the figure). I looked in vain for a single stigmatic plant or flower; but far across the swamp, a thousand feet distant, I at length discovered a single spire, composed entirely of pistillate

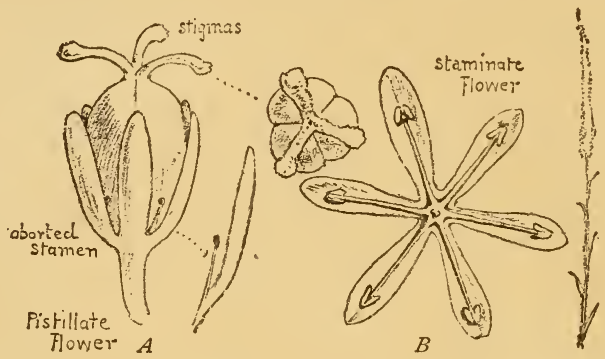

flowers, as shown at $\mathrm{A}$, and my magnifying-glass clearly revealed the pollen upon their stigmasdoubtless a welcome message brought from the isolated affinity afar by some winged sponsor, to

- whom the peculiar fragrance of the flower offers a special attraction, and thus to whom the fortunes of the devil's-bit have been committed.

THE CANADA LILY AND ITS COUSINS

The gorgeous Canada lily, Lilimm Canadense, flaunts its spotted yellow petals in the hope of 


\section{The Candda Lily and Its Cousins}

bewitching the leaf-cutter (or upholsterer) bees, on which it depends for fertilization. ?

This lily produces pollen as well as nectar to attract its insect visitors, its pollen supply greatly exceeding what is necessary for its own riy perpetuation. This pollen serves the upholsterer bee as food for its young. The leaf-cutter stores the pollen between the long hairs on its breast-a different method from that usually followed, most bees storing pollen in little baskets, developed, for that purpose, on their hind legs. The lily pictured in the accompanying illustration is not the identical lily here described, but a closely allied species often confounded with the Canada lily - namely, the fire lily, Lilium. Philadelphicum. The Canada species bows its head and dwells only in moist places, while the fire lily stands erect and can live in very dry soil. 
In strong contrast to the gay, pollen-loaded Canada lily is the pure white, sweetly scented Bermuda or Easter lily, Lilium Harrisi. Lubbock says, "There is not a hair or a line, not a.spot or a color, for which there is not a reason-which has not a purpose or a meaning in the economy of Nature." If this be true, what do the variations in these near cousins signify?

The answer to our question is not far to seek. The Canada lily desires the services of an insect that flies by day and that is a pollen-gatherer rather than a nectar-lover. Its vivid yellow tints are, therefore, all sufficient, making the flower most conspicuous and suggesting the character of the reward which it will bestow upon its guests in return for their courteous attendance.

The Bermuda lily, on the contrary, wishes to avail itself of the kind offices of a moth which flies only during the twilight hours and which is a honeytippler, caring nothing for pollen, since its eggs are deposited on the plants that feed its young. This lily, therefore, dons a white robe, which is more easily distinguished at dusk than any color, and as a further guide to its whereabouts and a hint of the sweets which it has to offer, it has acquired an extraordinary perfume. 


\section{The Dog-Tooth Violet}

THE DOG-TOOTH I'IOLET

The dainty little trout lilies, better known as “ dog-tooth violets," or " yellow adder's tongues," are among the first spring blossoms, blooming before the foliage is dense enough to shut out their beloved sunlight, which they are always turning on their stalks to follow. At night they fold their petals and sleep to avoid the darkness.

The drooping position of the bells compels the small butterflies and bees that befriend these violets to cling so closely to the style and stamens to avoid falling, while they sip their nectar, that they cannot fail both to receive and bestow pollen. It serves another purpose also, protecting the flowers from thievish ants, who are always thirsty for honey, but incapable of making the blossoms any return for their sweets. Even though they succeed in ascending the slippery stalk, they are sure to get a tumble when they try to round the curve to reach the flower itself.

Thus all the wonderful and fascinating attributes of the Lily family have been evolved, not merely to add to their beauty, but in obedience to the same law of co-operation that governs the rest of the plant world. As Henry Drummond says: "The loveliness, the variegations of shade and tint, the 
ornamentations, the scents, the shapes, the sizes of flowers, are all the gifts of co-operation. The flower in every detail is a monument to the co-operative principle."

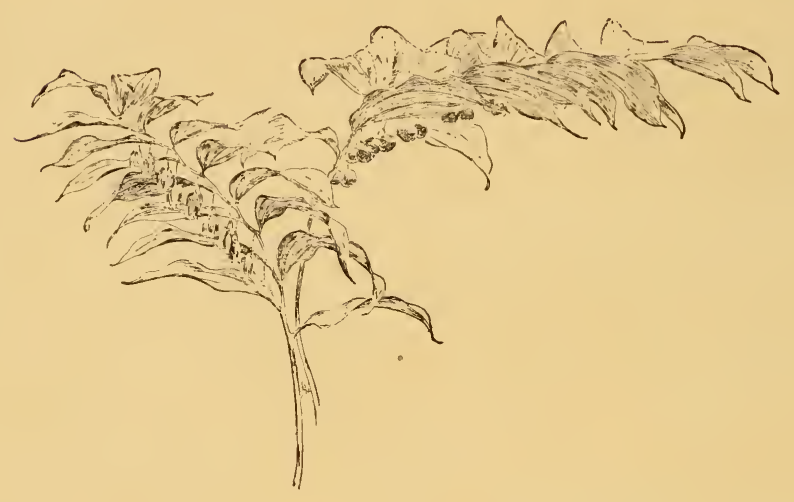




\section{Blossom Hosts and Insect Guests}

attaches its pollen masses to the bulging eyes, or perchance to the capillary tongue! And thus in endless modifications, evidences all of the same deep vital purpose.

And what is an orchid? How are we to know

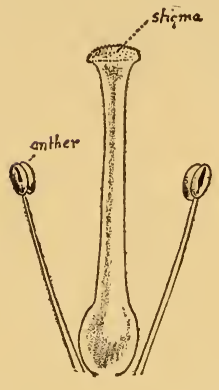

FIG. I.

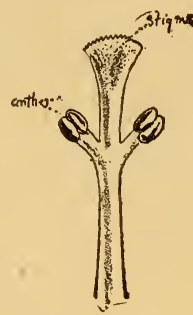

in the popular mind. Of over 3, Ooo known species of orchids, it is true a

great majority are air-plants, or epiphytes-growing upon trees and other plants, obtaining their sustenance from the air, and not truly parasitic; but of the fifty-odd species of the northeastern United States, not one is of this character, all growing in the ground, like other plants. It is only by the botanical structure of the flowers that the orchid may be distinguished, the epiphytic character being of little significance botanically.

A brief glance at this structural peculiarity may properly precede our more elaborate consideration of a few species of these remarkable flowers. 
The orchids are usually very irregular, and sixparted. The ovary is one-ceiled, and becomes a pod containing an enormous yield of minute, sporelike seeds (Fig. 3) in some species, as in the vanilla pod, to the number of a million, and in one species of the maxillaria, it has been computed, I,750,000.

The pollen, unlike ordinary flowers, is gathered together in waxy masses of varying consistency, variously formed and disposed in the blossom, its
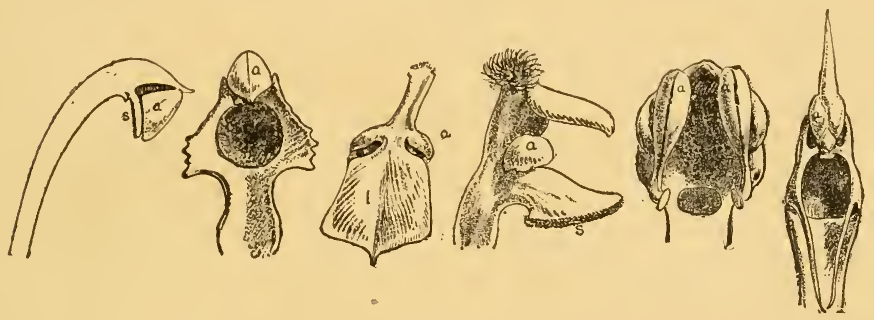

FIG. 2 .

grains being connected with elastic cobwebby threads, which occasionally permit the entire mass to be stretched to four or five times its length, and recover its original shape when released. This is specially noticeable in the showy orchid, later described. The grains thus united are readily disentangled from their mass when brought into contact with a viscid object, as the stigma.

But the most significant botanical contrast and distinction is found in the union of the style and 
stamens in one organ, called the column (Fig. 2), the stigma and the pollen being thus disposed

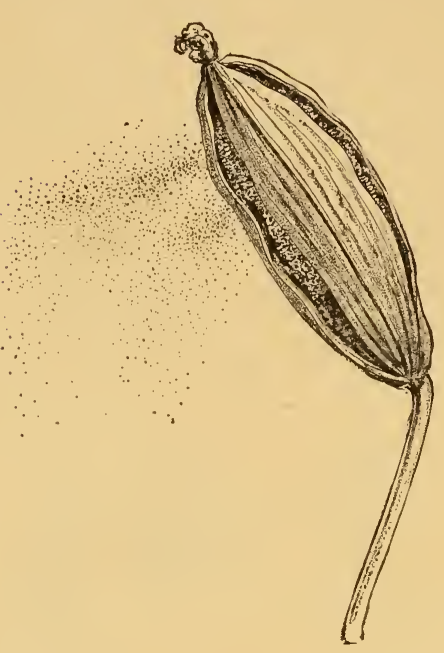

FIG. 3. upon a single common stalk. The contrast to the ordinary flower will be readily appreciated by a comparison of the diagrams of Fig. I.

When, therefore, we find a blossom with the anthers or pollen receptacle united to a stalk upon which the stigma is also placed, we have an orchid.

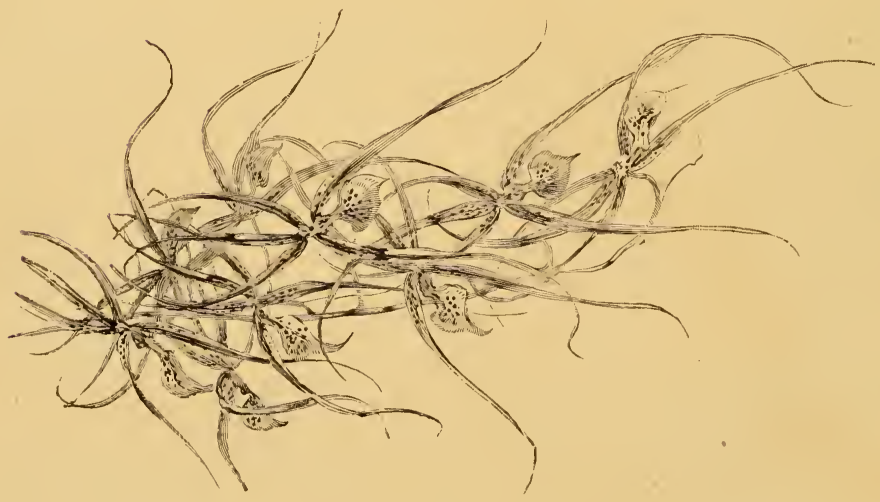




\section{Tile Showy Orchid}

A group of the beautiful showy orchids is shown in my full-page illustration. A farorite haunt for these choice blossoms is the dark, damp, hemlock woods. Against this background their deep pink hoods and pure white lips stand out most conspicuously, justifying fully the flower's specific name of "spectabilis."

In the showy orchid we have what would appear a clear adaptation to the head of a bee, though one which might also arail of the service of an occasional butterfly. An enlarged view of the blossom is seen in

Fig. I, and in Fig. 2 a still greater enlargement of the column.

I have seen many specimens with the pollen masses withdrawn, and others with their stigmas well covered with the grains. Though I have never seen an insect at work upon it in its haunt, the whole form of the 


\section{Blossom Hosts and Insect Guests}

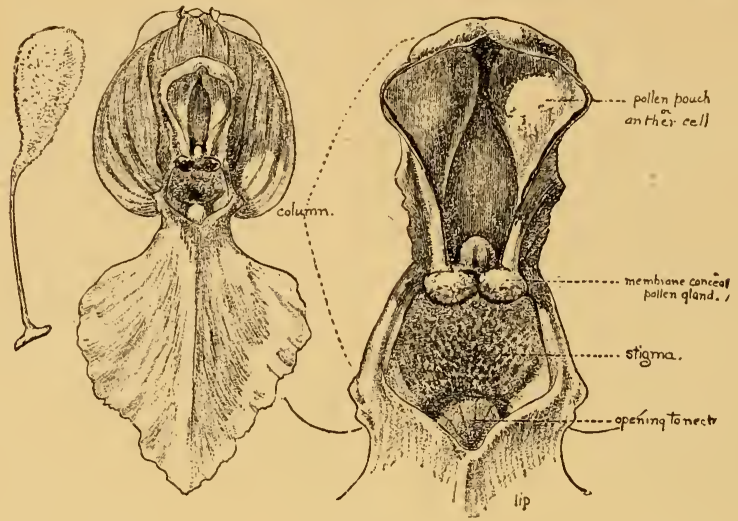

FIG. I.

opening of the flower would seem to imply a bee, particularly a bumblebee. If we insert the point of a lead-pencil into this opening, thus imitating the entrance of a bee, its bevelled surface comes in contact with the riscid disks by the rupture of a veil of membrane, which has hitherto protected them. The disks adhere to the pencil, and are withdrawn upon it (Fig. 3). At first in upright position, as at $A$, they soon assume a forward
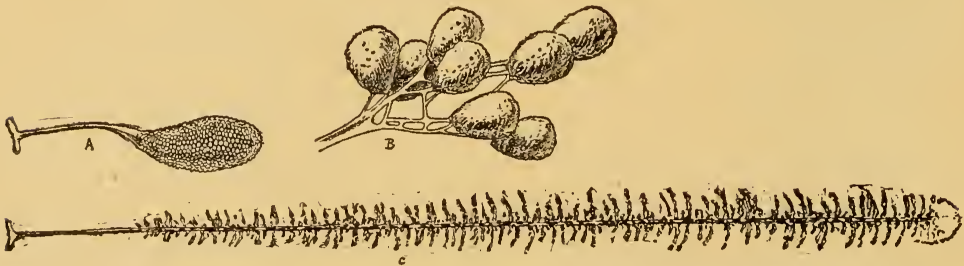
FIG. 2. 


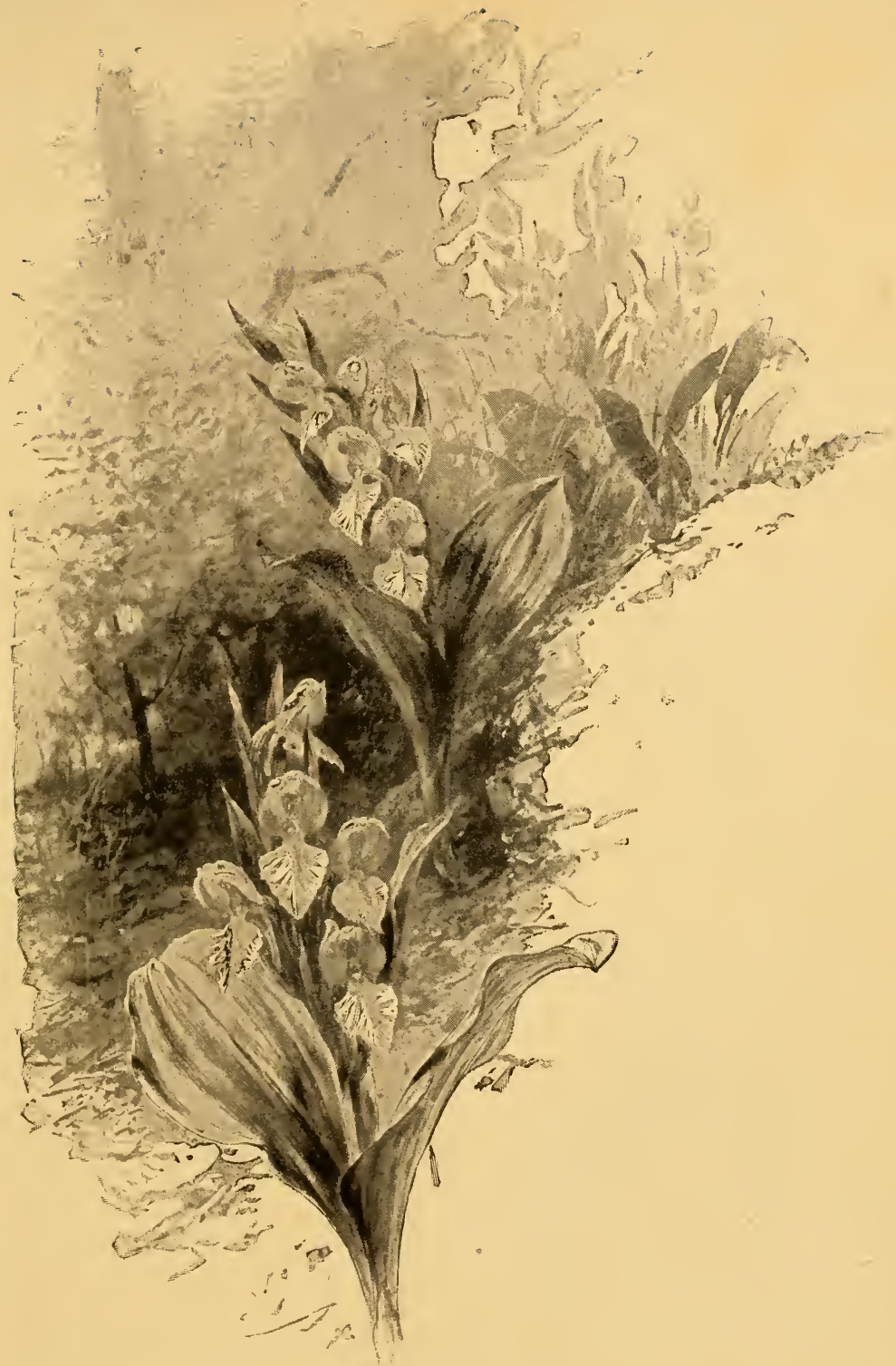




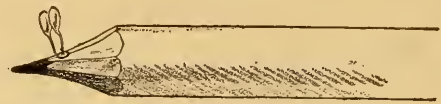

A

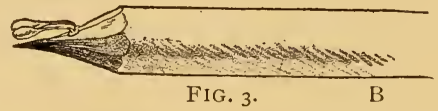

inclination, as shown at $B$. The nectary is about the length of a bumblebee's tongue, and is, moreover, so amply expanded at the throat below the stigma as to comfortably admit its wedge-shaped head. The three progressive diagrams (Fig. 4) indicate the result in the event of such a visit.

The pollen disks are here very close together, and are protected within a membranous cup, in which they sit as in a socket. As the insect inserts his head at the opening $(A)$, it is brought against this

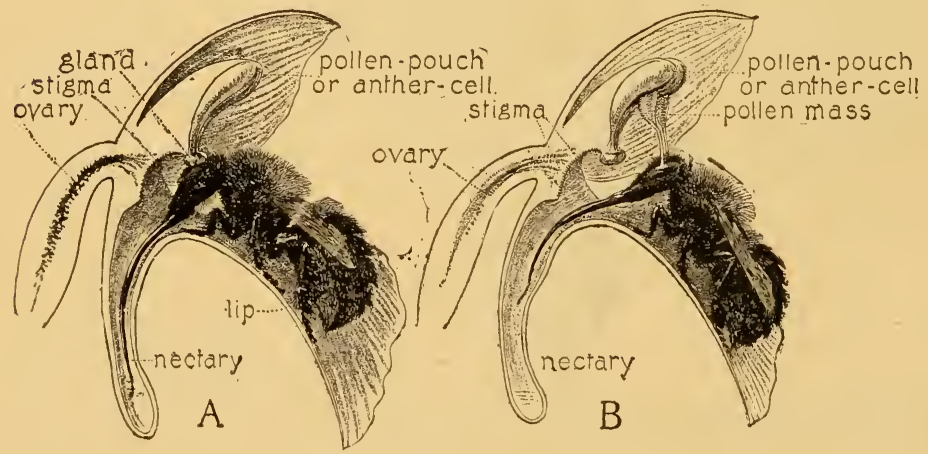

FIG. 4 . 


\section{The Showey Orchid}

tender membrane, which ruptures and exposes the viscid glands of the pollen masses, which become instantly attached to the face or head, perhaps the eyes, of the burly visitor. As the insect retreats from the flower, one or both of the pollinia are withdrawn, as at B. Then immediately follows a downward movement, which exactly anticipates the position of the stigma, and as the bee enters the next flower the pollen clubs are forced against it (C).

In the case of a smaller bee visiting the flower, the insect would find it necessary to creep farther into the opening, and thus

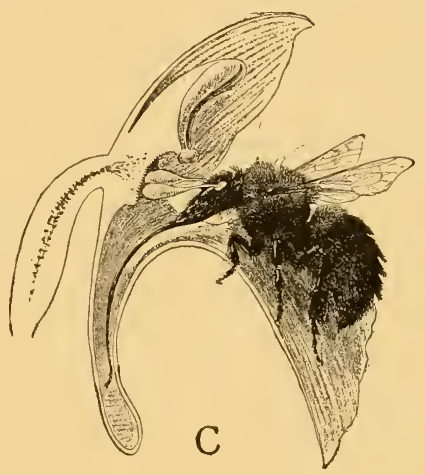

FIG. 4 . might bring its thorax against the pollen-glands. In either case the change of position in the pollinia would insure the same result.

The entrance to the showy orchid's nectary is so formed as to insure the approach of the insect from the front - the only way in which the desired result can be accomplished. This direct approach, so necessary in many orchids, is insured by various devices-by the position of the lip upon which the 
insect must alight; by the narrowed entrance of the throat of the flower in front of the nectary; by a fissure in the centre of the lip, by which the tongue is conducted, etc.

In other species allied to the above we find adaptations to the thorax, the eyes, and the face of the intended visitor; and there is still another group whose structure is distinctly adjusted to the tongues of insects-adaptations not merely of position of pollen masses, but even to the extent of a special modification in the entrance to the flower and the shape of the sticky gland, by which it may more securely adhere to that sipping member.

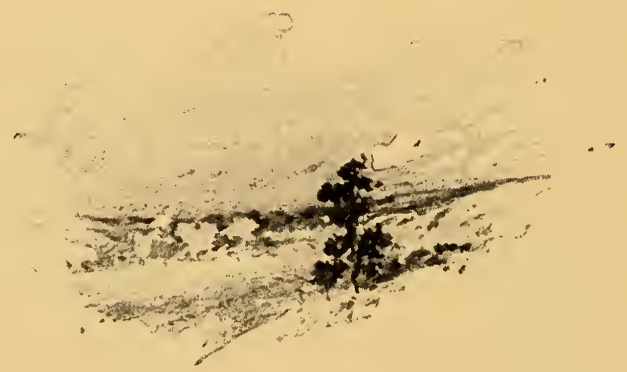




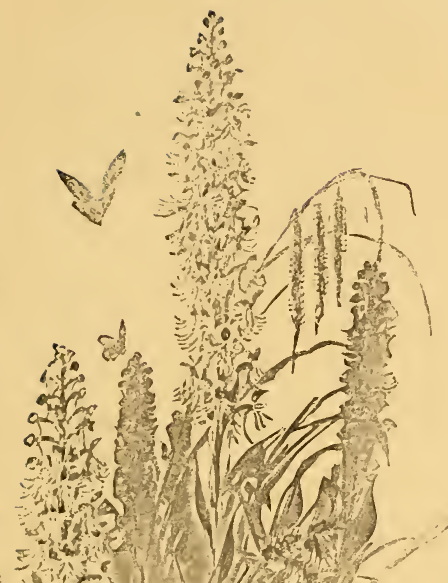

The Purple-Fringed

AND THE

Ragged Orchin

IN the common pretty purple-fringed orchid, $H$. psycodes, whose dense cylindrical spikes of plumy blossoms occasionally empurple whole marshes, the pollen is tucked away in two parallel pouches, one on either side of the stigma (Fig. I). In this case the eyes of sipping butterflies occasionally get their decoration of a tiny golden pollen club, but more frequently their tongues.

If, in visiting the purple-fringed orchid, the butterfly should approach directly in front of the flower, as the bee does in the showy orchid, he might sip the nectar indefinitely and withdraw his tongue without bringing it in contact with the viscid pollen disks. But in the dense crowding of the flowers, 


\section{Blossom Hosts and Insect Guests}

over which the insect flutters indiscriminately, the approach is oftenest made obliquely, and thus the tongue brushes the disk on the side approached, and the pollen mass is withdrawn. But an examination

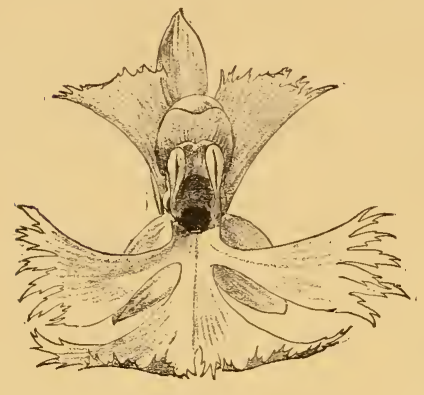

FIG. I. of this orchid affords no pronounced evidence of any specific intention. There is no unmistakable sign to demonstrate which approach is preferred by the flower, and this dependence on the insect's tongue or eye would seem to be left to chance.

In another kindred species, however, we have a distinct provision which insures the proper approach of the tongue-one of many similar devices by which the tongue is conducted directly to one or other of the pollen disks.

THE RAGGED ORCHID

This is the ragged orchid, $H$. lacera, a blossom far less fortunate in its attributes of beauty than the foregoing member of the family ; its long, scattered spike of greenish white flowers being so inconspicuous in its grassy haunt as often to conceal the fact of its frequency. The initial illustration represents a group of these blossoms and an I 36 


\section{The Purple-Fringed and the Ragged Orchid}

individual flower is shown enlarged at Fig. 2, the lip here cut with a lacerated fringe. The pollen-pouches approach slightly at the base, directly opposite the nectary, where the two viscid pollen-glands stand on guard. Now, were the opening of the nectary at this point unimpeded, the same condition would exist as in the purple-fringed orchid-the tongue might be inserted between the pollen disks and withdrawn without touching them. But here comes the remarkable and very exceptional provision to make this contact a certainty - a suggestive structural feature of this flower, of which I am surprised to

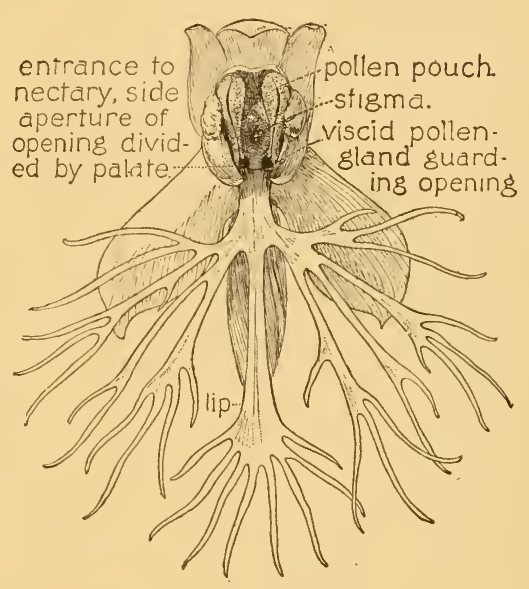

FIG. 2. find no mention, either in our botanies or in the literature of cross-fertilization, so far as I am familiar with its bibliography. The nectary here, instead of being freely open, as in other orchids described, is abruptly closed at the central portion by a firm protuberance or palate, which projects downward from the base of the stigma, and closely meets the lip below. 
The Purple-Fringed and the Ragged Orchid

the tongue (B) removes the pollen from its pouch. At $\mathrm{C}$ it is seen entirely free and upright, from which position it quickly assumes the new attitude shown at D. As the tongue is now inserted into the subsequent blossom, this pollen mass is thrust against the stigma (E), and a few of the pollen grains are
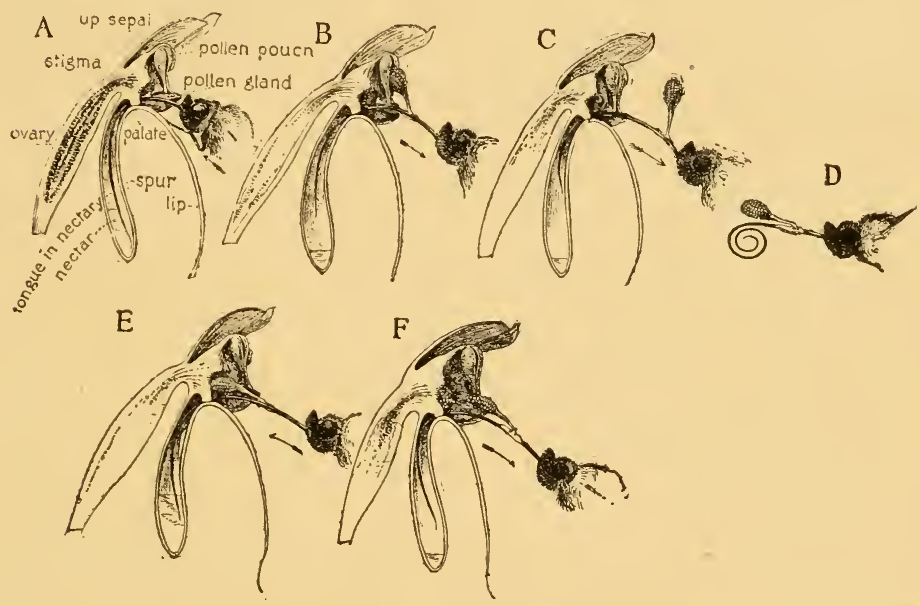

FIG. 4.

thus withheld upon its viscid surface as the insect departs $(\mathrm{F})$.

Another similar derice for assuring the necessary side approach is seen in the tubercled or small pale green orchis, H. flawa (Fig. 5), a yellowish spiked species, more or less common in swamps and rich alluvial haunts. 
Blossom Hosts and Insect Gulests

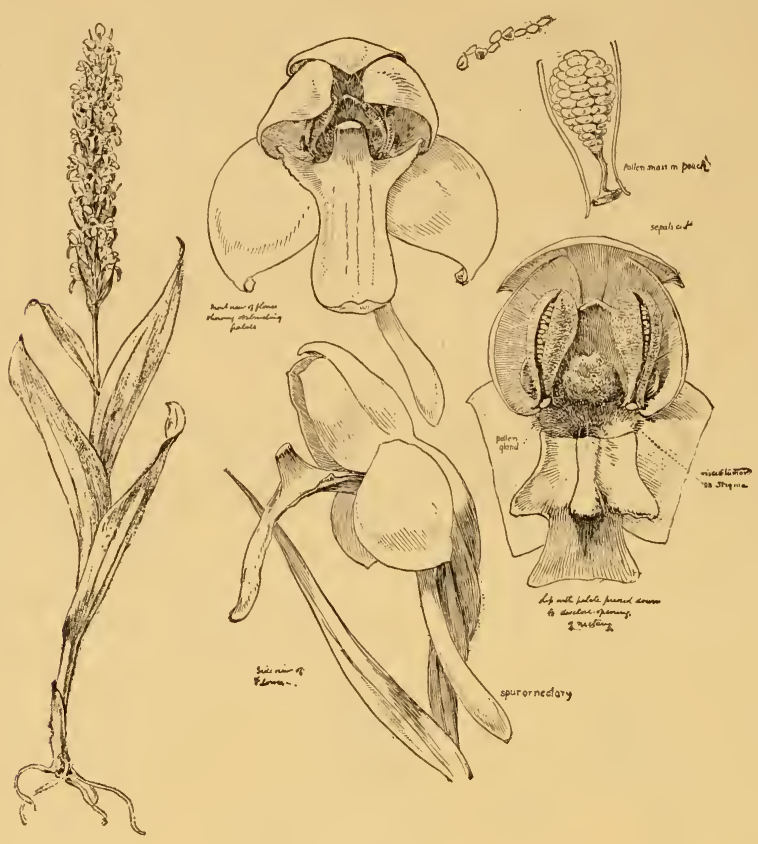

FIG. 5 .

In the small pale green species this "tubercle," instead of depending from the throat, grows upward from the lip.

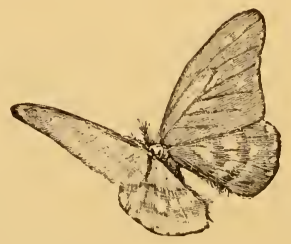




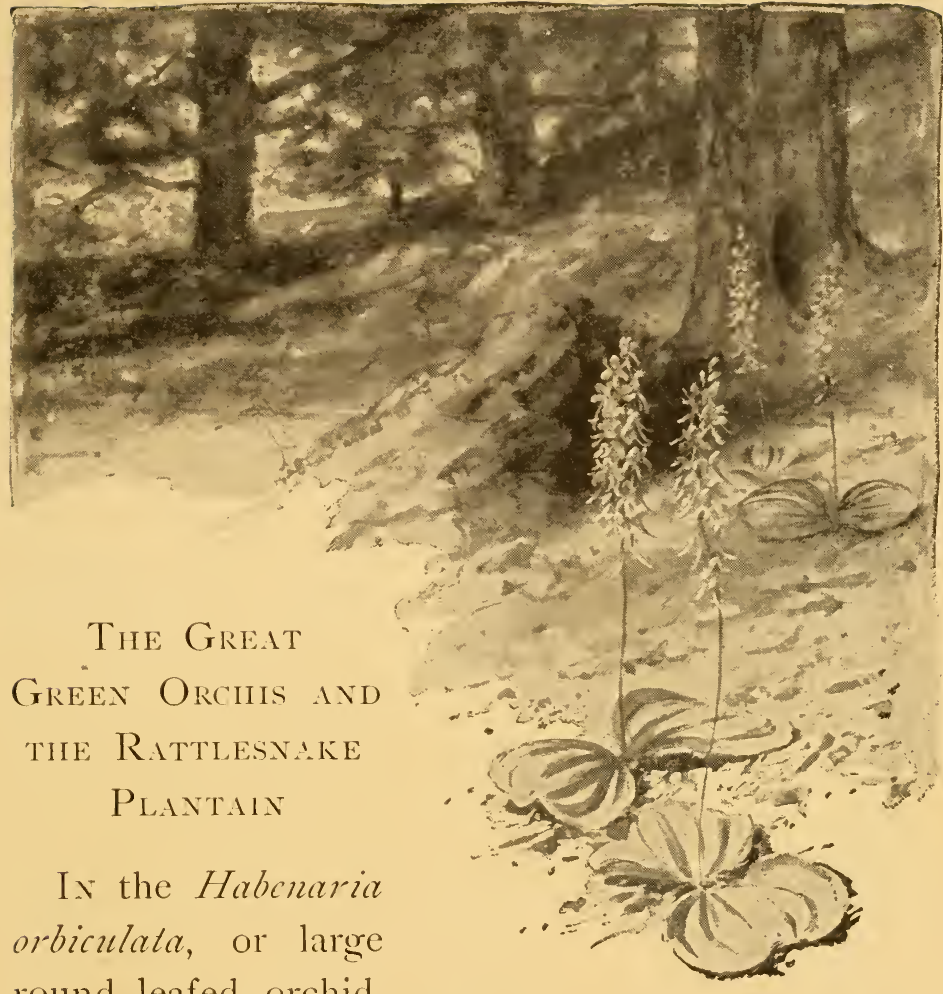
round-leafed orchid, sometimes called the great green orchis, we have a remarkable example of a form of floral construction which insures the transfer of the pollen on the eyes of the visiting insect. The structure and mechanism of this flower have been admirably described by Asa Gray.

All orchid-hunters know this most exceptional example of our local flora, and the thrill of delight experienced when one first encounters it in the 
mountain wilderness, its typical haunt, is an event to date from-its two great, glistening, fluted leaves, sometimes as large as a dinner-plate, spreading flat upon the mould, and surmounted by the slender

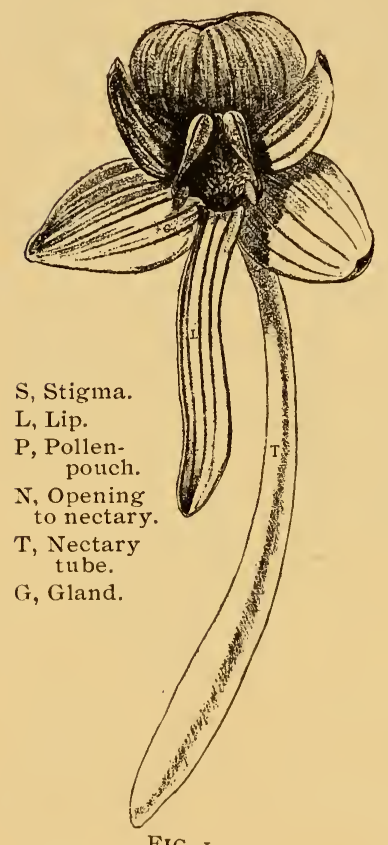

FIG. I. leafless stalk, with its terminal loose raceme of greenishwhite bloom.

A single blossom of the species is shown in Fig. I, the parts indexed. The opening to the nectary is seen just below the stigmatic surface, the nectary itself being nearly two inches in length. The pollen is in two club-like bodies, each hidden within a fissured pouch on either side of the stigma, and coming to the surface at the base in their opposing sticky disks as shown. Many of the group Habenaria or Platanthera, to which this flower belongs, are similarly planned. But mark the peculiarly logical association of the parts here exhibited. The nectary implies a welcome to a tongue two inches long, and will reward none other. This clearly shuts out the 


\section{The Great Green Orchis}

bees, butterflies, and smaller moths. What insect, then, is here implied? The sphinx-moth again, one of the lesser of the group. A larger individual might sip the nectar, it is true, but its longer tongue would reach the base of the tube without effecting the slightest contact with the pollen, which is of course the desideratum here embodied, and which has reference to a tongue corresponding to the length of the nectary. There are many of these smaller sphinxes. Let us suppose one to be hovering at the blossom's throat. Its slender capillary tongue enters the opening. Ere it can reach the sweets, the insect's head must be forced well into the throat. of the blossom, where we now observe a most remarkable special provision, the space between the two pollen disks being exactly adjusted to the diameter of the insect's head.

What follows this entrance of the moth is plainly pictured in the progressive series of illustrations (Fig. 2). A represents the insect sipping; the sticky disks are brought in contact with the moth's eyes, to which they adhere, and by which they are withdrawn from their pouches as the moth departs (B). At this time they are in the upright position shown at $\mathrm{C}$, but in a few seconds bend determinedly downward and slightly toward each 
other to the position D. This change takes place as the moth is flitting from flower to flower. At $\mathrm{E}$

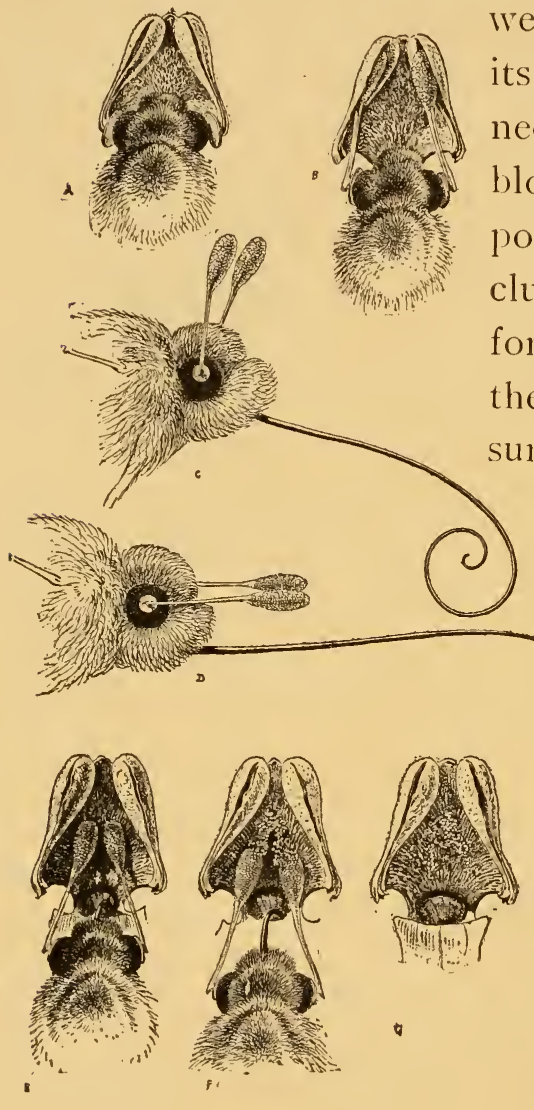

FIG. 2. we see the moth with its tongue entering the nectary of a subsequent blossom. By the new position of the pollen clubs, they are now forced directly against the stigma (E). This surface is viscid, and as the insect leaves the blossom retains the grains in contact (F), which in turn withdraw others from the mass by means of the cobwebby threads by which the pollen grains are continuously attached. At G we see the orchid after the moth's visit-the stigma covered with pollen, and the flower thus cross-fertilized. 


\section{The Rattlesmake-Plantain}

In effecting the cross-fertilization of one of the younger flowers, its eyes are again brought into contact with this second pair of disks, and these, with their pollen clubs, are in turn withdrawn, at length, perhaps, resulting in such a plastering of the insect's eyes as might seriously impair its vision, were it not fortunately of the compound sort.
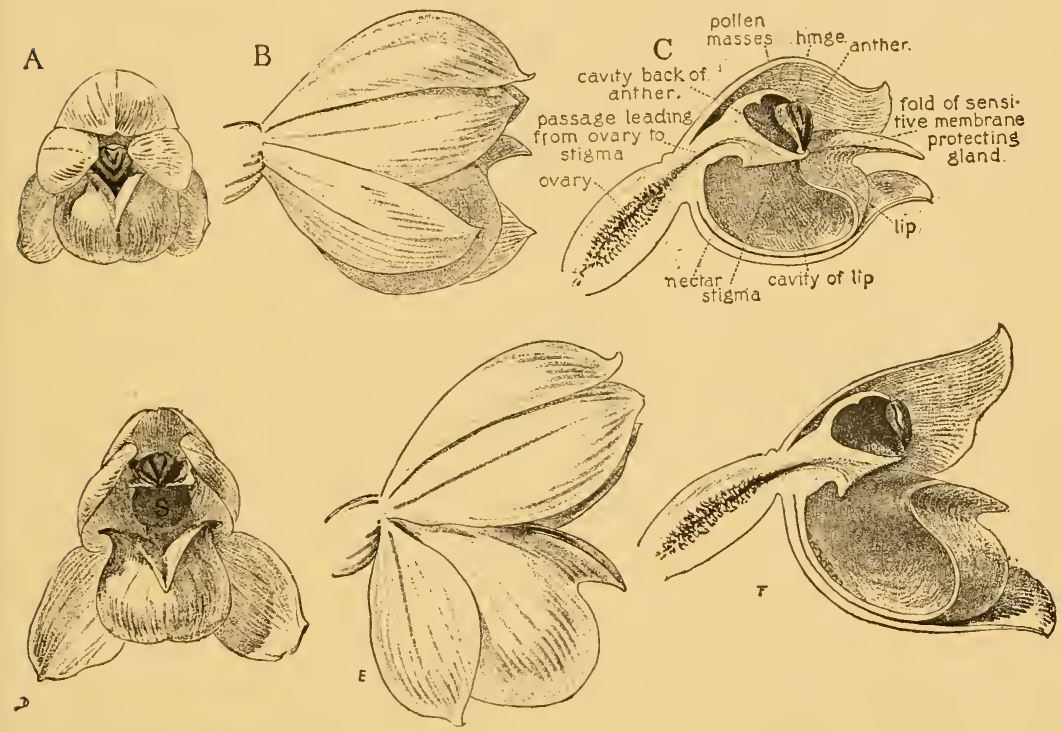

FIG. 3.

THE RATTLESNAKE-PLANTAIN

One of the most beautiful of our orchids, though its claims to admiration in this instance are chiefly confined to the foliage, is the common rattlesnake. 
plantain, Goodyera, its prostrate rosettes of exquisitely white reticulated leaves carpeting many a nook in the shadows of the hemlocks, its dense spikes of yellowish-white blossoms signalling their welcome to the bees, and fully compensating in interest what they may lack in other attractive attributes.
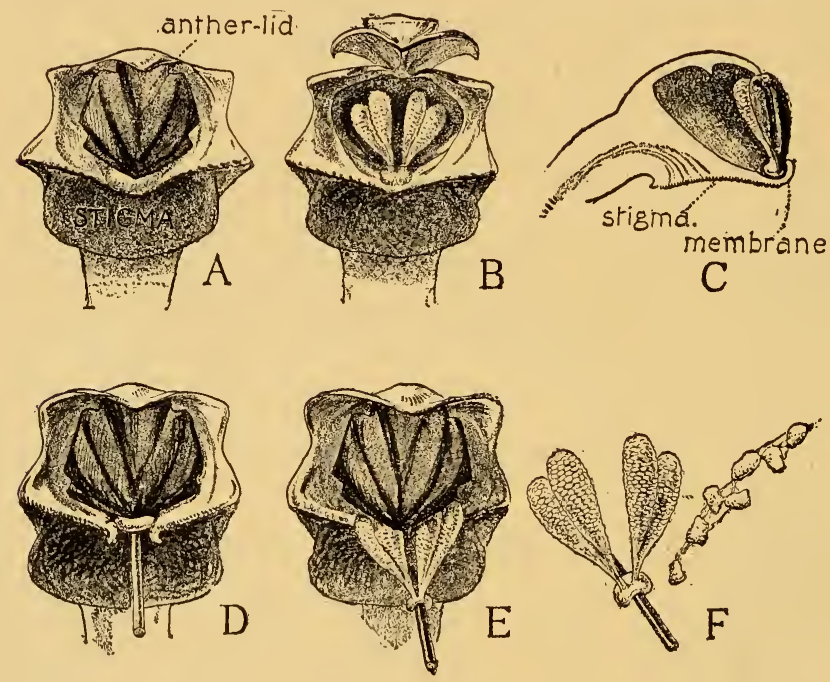

FIG. 4.

The single flower is shown enlarged in Fig. 3, A, a young blossom, with analyses $\mathrm{B}$ and $\mathrm{C}$, the latter indexed; $\mathrm{D}$, an older blossom, with similar analyses $\mathrm{E}$ and $\mathrm{F}$. Both sorts are to be found upon every spike of bloom, as the inflorescence begins at the base and proceeds upward. As we look 


\section{The Rattlesnake-Plantain}

into the more open flower, we observe a dark-colored speck, which, by analysis, proves to be the lid of the anther. This portion is further shown enlarged in Fig. 4, A. If we gently lift it with a pin, we disclose the pollen masses in the cavity B

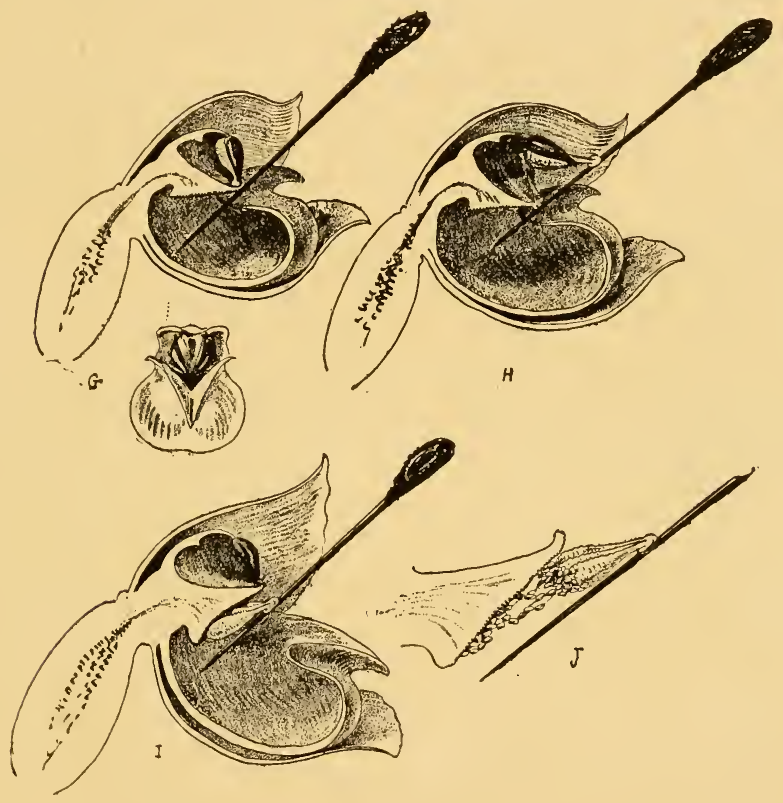

FIG. 5.

thus opened (C, profile section), the two pairs united to a common viscid gland at the base, this gland again secreted behind a veil of moist membrane, as also shown at B. This membrane is, moreover, very sensitive to the touch. Below the flattened tip of 
the column, and at a sharp inward angle, is the stigma. In the freshly opened flower (Fig. 3, A) the column inclines forward, bringing the anther low down, and its base directly opposite the $\mathrm{V}$-shaped orifice in the lip, which also is quite firmly closed beneath the equally converging upper hood of the blossom. The entrance is thus much narrowed. If

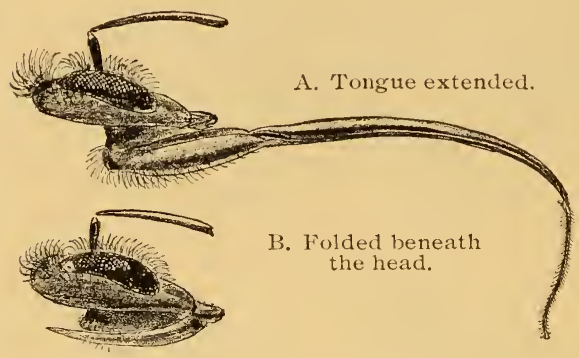

we insert a pin in this $V^{\top}$-shaped entrance, it comes in contact with the sensitive membrane below the anther, and it is immediately ruptured, as shown at Fig. 4, D. The sticky gland is brought into immediate contact, and clasps the pin, which, now being withdrawn, brings away the pollen, as in $\mathrm{E}$ and $\mathrm{F}$. Thus it is naturally removed on the tongue of its sipping bee.

The further demonstration will be better shown by profile sections (Fig. 5). Nectar is secreted in the hollow of the lip indicated, somewhat as in the cypripedium. If we now imitate with a probe the habit of the insect and the action of its tongue, we may witness a beautiful contrivance for cross-fertilization. 


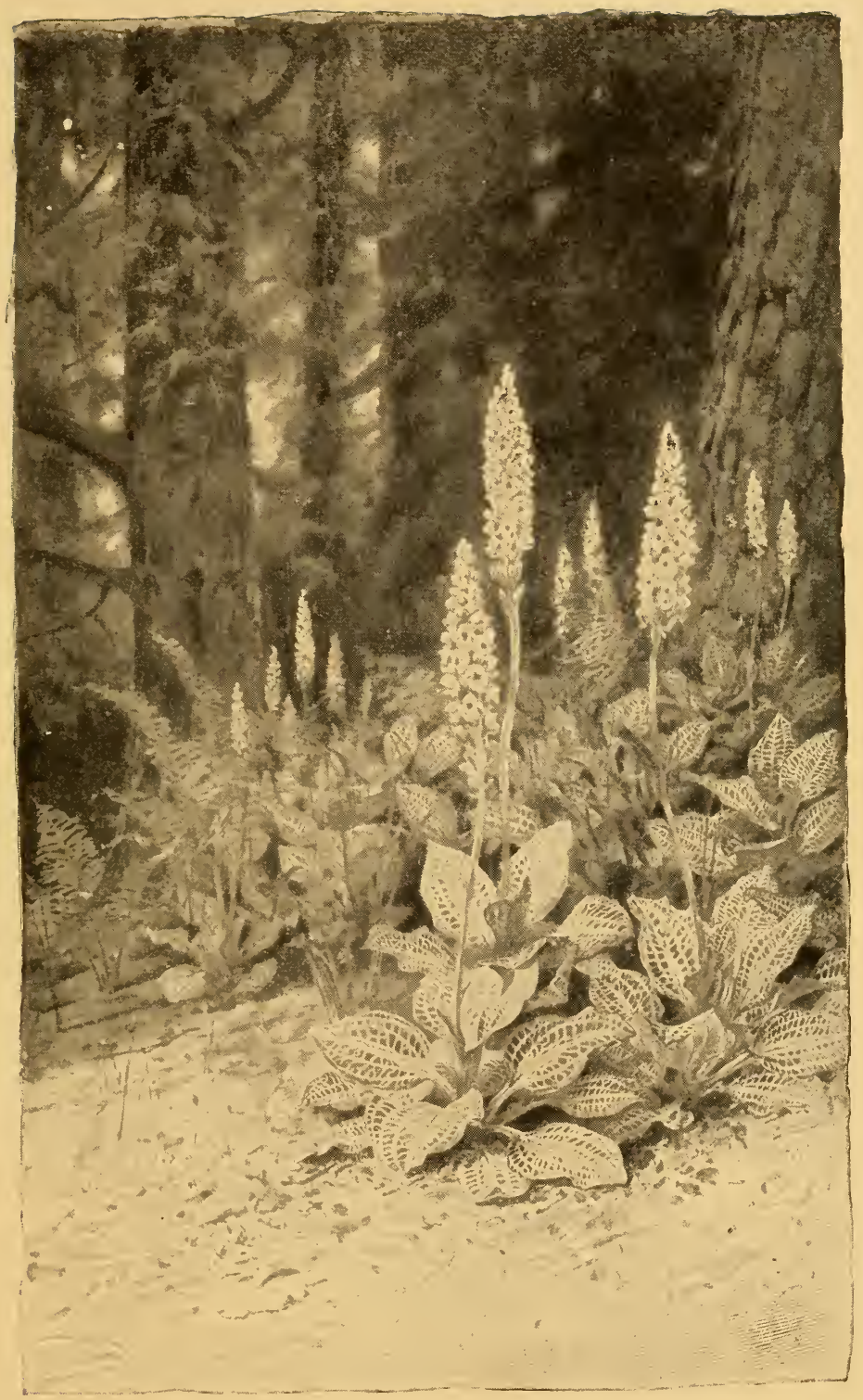




\section{Blossom Hosts and Insect Guests}

We will suppose the bee to be working at the top of the spike. He thrusts his tongue into the narrow opening $(\mathrm{G})$. The membrane protecting the pollen-gland, thus surely touched, ruptures as described, and the exposed gland attaches itself to the tongue, being withdrawn as at $\mathrm{H}$, and located on the insect's tongue, as in F, Fig. 4. The bee leaves this flower cluster and flies to another, upon which it will usually begin at the bottom. The flower thus first encountered is an old bloom, as in Fig. 3, D. Its sepals are more spreading, the lip slightly lowered, and the column so changed as to present the plane of the stigma in such a new position as to invariably receive the pollen. The tongue of a bee entering this flower conveys the pollen directly against the stigmatic surface (I), which retains its disentangled fecundating grains, as at $\mathrm{J}$, and the flower's functional adaptations are fulfilled.

In the allied spiranthes, or lady's-tresses, a somewhat similar mechanism prevails.

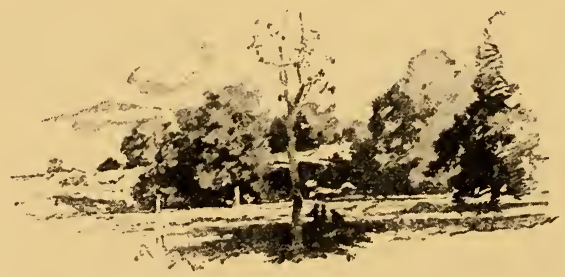




\section{Arethusa and Pogonia}

Tite orchid belle of our swamps, so fitly named for the water nymph of the ancients, Arethusa, A. bul. bosa, presents one of the most interesting problems in fertilization furnished by our wild orchids. I have indicated a group of the orchids in their usual marshy haunt, and in Fig. I, separately, a series of

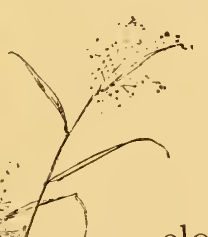
diagrams presents sections of the flower, natural size and duly indexed. The column is here quite elongated, forked at the tip, the space between the forks occupied by the anther, which is hinged to the upper division. This anther lid is closed tightly, with the sticky mass of pollen hidden behind it in the cavity. The stigma is on the external inner side of the lower division, and thus 
distinctly separated from the pollen. The "lip" is extended forward as a hospitable threshold to the insect. And to what insect might we assume this invitation of color, fragrance, nectar, and threshold to be extended?

Let us consider the flower simply as a device to insure its own cross-fertilization. The insect is welcomed; it must alight and sip the nectar; in departing it must bear away this pollen upon its body, and convey it to the next Arethusa blossom which it visits, and leave it upon its stigma. The nectar is here secreted in a well-not very deep -and the depth of this nectar from the entrance is of great significance among all the flowers, having distinct reference to the length of the tongue which is expected to sip it. In the Arethusa, it is true, the butterfly or moth might sip at the throat of the flower, but the long tongues of these insects might permit the nectary to be drained without bringing their bodies in contact with the stigma. Smaller insects might creep into the nectary and sip without the intended fulfilment. It is clear that to neither of such visitors is the welcome extended. What, then, are the conditions embodied? The insect must have a tongue of such a length that, when in the act of 


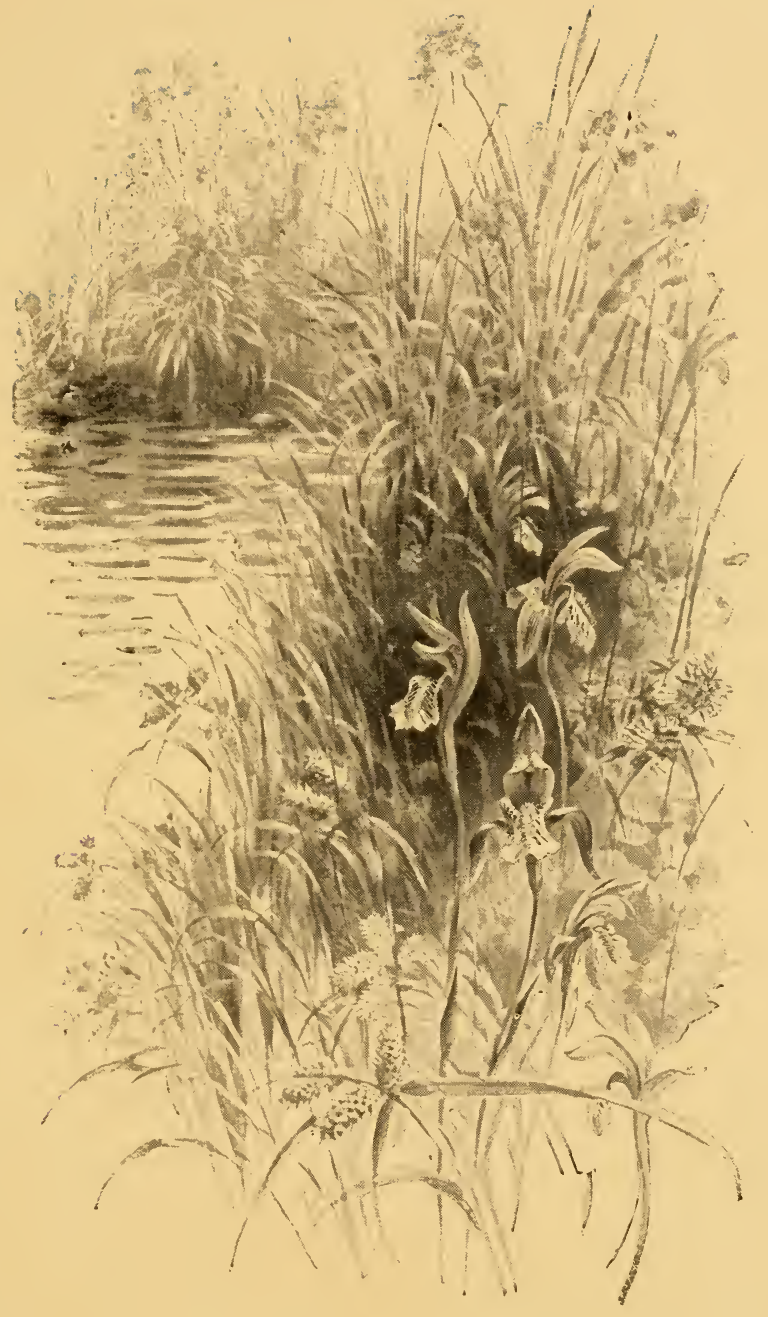


sipping, its head must pass beyond the anther well into the opening of the flower. Its body must be sufficiently large to come in contact with the anther. Such requisites are perfectly fulfilled by the bumblebee, and we may well hazard the prophecy that the Bombus is the welcomed affinity of the flower.

The diagrams (Fig. I) sufficiently illustrate the

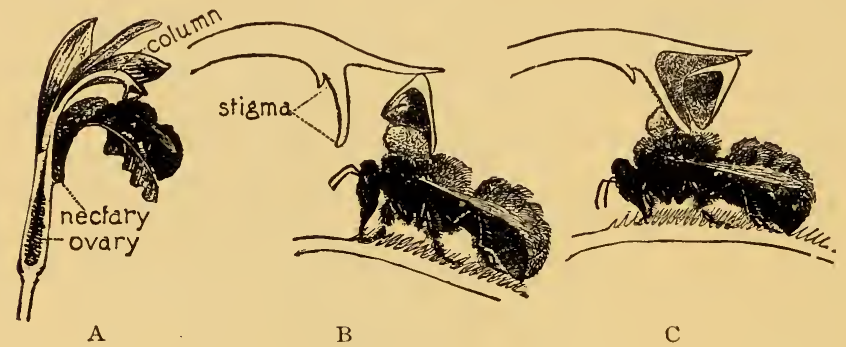

FIG. I.

efficacy of the beautiful plan involved. At A the bee is seen sipping the nectar. His forward movement thus far to this point has only seemed to press the edge of the anther inward, and thus keep it even more effectually closed. As the bee retires (B), the backward motion opens the lid, and the sticky pollen is thus brought against the insect's back, where it adheres in a solid mass. He now flies to the next Arethusa blossom, enters it as before, and 


\section{Arethusa and Pogonia}

in retiring slides his back against the receptive viscid stigma, which retains a portion of the pollen, and thus effects the cross-fertilization (C). Professor Gray surmised that the pollen was withdrawn on the insect's head, and it might be so withdrawn, but in other allied orchids of the tribe Arethusa, however, in which the structure is very similar, the pollen is deposited on the thorax, and such is probably the fact in this species. In either case, cross-fertilization would be effected. Nothing else is possible,

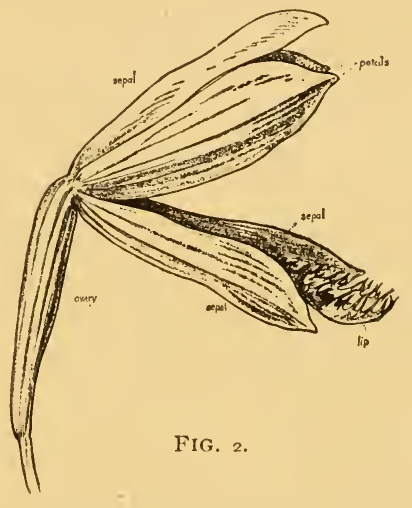
and whether it is Bombus or not that effects it, the method is sufficiently evident.

The sweet-pogonia, or grass-pink of our sedgy swamps (Pogonia ophioglossoides), a solitary rosy blossom, nodding on its slender stem above the grasses, is no less welcome an episode to the sauntering botanist than its cousin Arethusa. Its perfume, suggesting ripe red raspberries, is unique in the wild bouquet.

The bee as well as the botanist recognizes these flowers as closely akin, and visits the pogonia 


\section{Blossom Hosts and Insect Gulests}

with as much pleasure and profit as the Arethusa.

A profile view of the pogonia is shown in Fig. 2, its various parts indexed. Concealed behind the
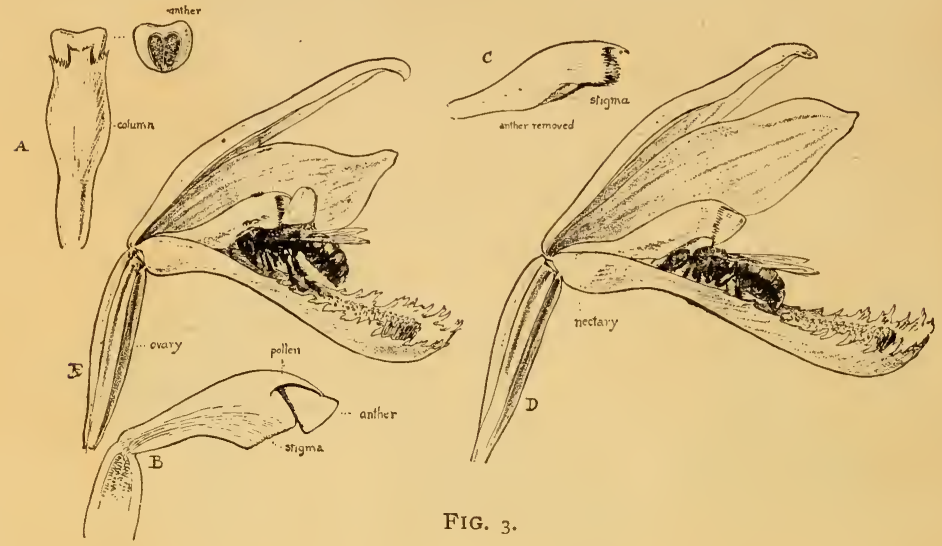

FIG. 3 .

petals is the column indicated at A, Fig. 3. E and D, Fig. 3, illustrate the method of pollination, which is so nearly identical with that of Arethusa that further analysis seems superfluous.

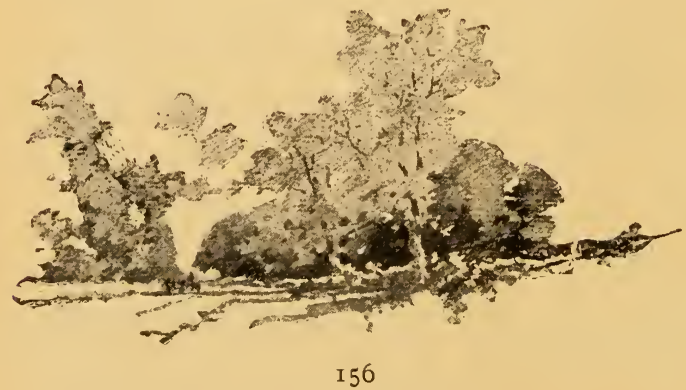




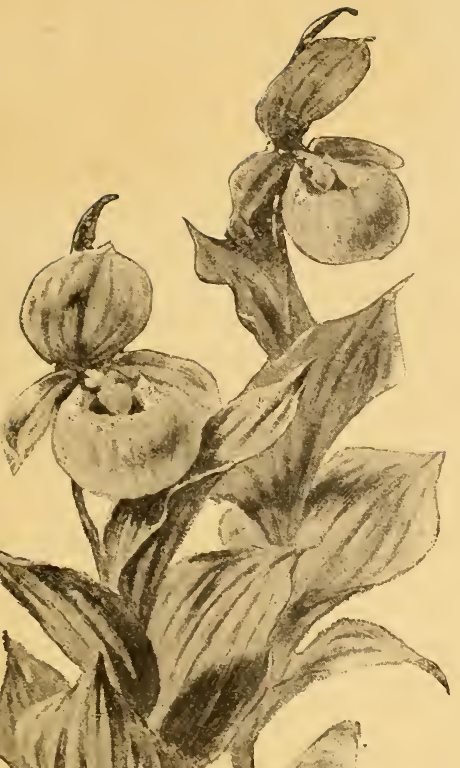

The Moccashe-Flower

Or all our native orchids, at least in the northeastern United States, the cypripedium, or moccasinflower, is perhaps the gencral favorite, and certainly the most widely known. This is readily accounted for not only by its frequency, but by its conspicuousness. The term "moccasin-flower" is applied more or less indiscriminately to all species. The flower is also known as the lady's-slipper, more specifically V'enus's-slipper, as warranted by its generic botanical title, from a fancied resemblance in the form of the inflated lip, which is characteristic of the genus. We may readily infer that the fair goddess was not consulted at the christening. There are six native species of the cypripedium in this Eastern region, varynng in shape and in color - shades of white, yellow, 


\section{Blossom Hosts and Insect Guests}

crimson, and pink. The mechanism of their crossfertilization is the same in all, with only slight modifications.

Our initial illustration shows the whtie species, but the most common of the group, the $C$. acaule,

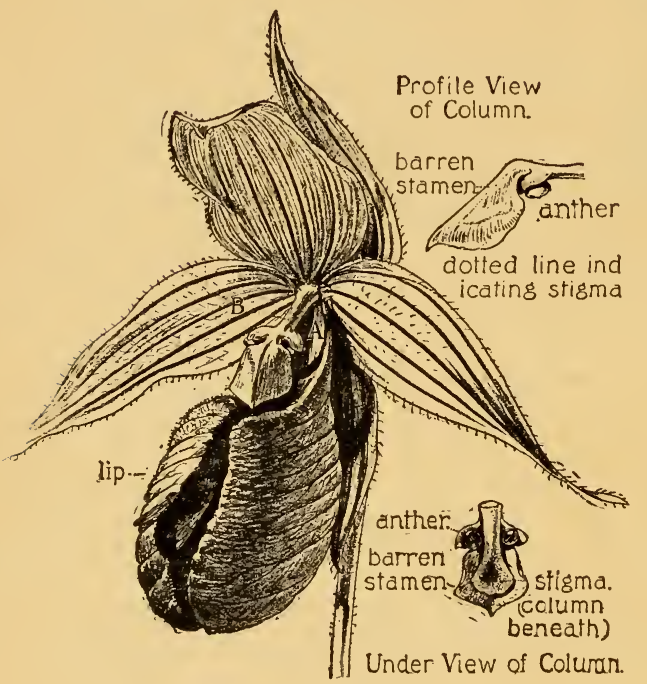

FIG. $x$. widely known as the moccasin-flower, whose large, nodding, pale crimson blooms we so irresistibly associate with the cool hemlock woods, will afford a better illustration of the general method of fertilization employed by the tribe.

The lip in all the cypripediums is more or less sac-like and inflated. In the present species, $C$. acaule, however, we see a unique variation, this portion of the flower being conspicuously bag-like, and cleft by a fissure down its entire anterior face. In Fig. I is shown a front view of the blossom, showing this fissure. The "column" (B) in the cypripedium is very 
distinctive, and from the front view is very noncommittal. It is only as we see it in side section, or from beneath, that we fully comprehend the disposition of stigma and pollen. Upon the stalk of this column there appear from the front three lobes-two small ones at the sides, each of which hides an anther attached to its under face-the large terminal third lobe being, in truth, a barren rudiment of a former stamen, and which now overarches the stigma. The relative position of these parts may be seen in the under view.

The anthers in this genus, then, are two, instead of the previous single anther with its two pollencells. The pollen is also quite different in its character, being here in the form of a pasty mass, whose entire exposed surface, as the anther opens, is coated with a very viscid gluten.

With the several figures illustrating the crossfertilization, the reader will readily anticipate any description of the process, and only a brief commentary will be required in my text.

I have repeatedly examined the flowers of C. acaule in their haunts, have observed groups wherein every flower still retained its pollen, others where one or both pollen masses had been withdrawn, and in several instances associated with 
them I have observed the inflated lip most outrageously bruised, torn, and battered, and occasionally perforated by a large hole. I had observed these facts in boyhood. The inference, of course, was that some insect had been guilty of the mutilation; but not until I read Darwin's description of the

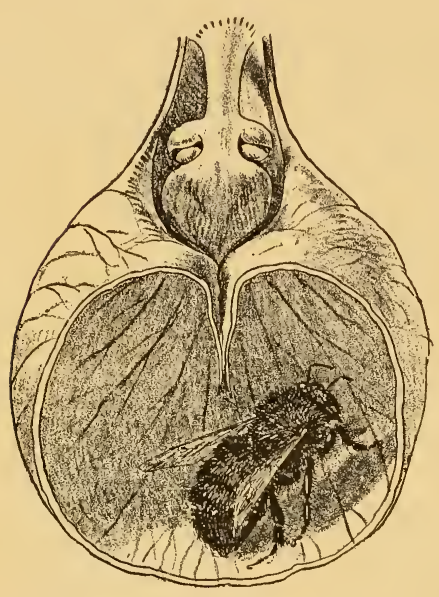

FIG. 2. cross-fertilization of this species did I realize the full significance of these telltale evidences of the escape of the imprisoned insect. Since that time, many years ago, I have often sat long and patiently in the haunt of the cypripedium awaiting a natural demonstration of its crossfertilization, but as yet no insect has rewarded my devotion.

At length, in hopelessness of reward by such means, I determined to see the process by more prosaic methods. Gathering a cluster of the freshly opened flowers, which still retained their pollen, I took them to my studio. I then captured a bumblebee, and forcibly persuaded him to enact the demonstration which I had so long waited for 
him peaceably to fulfil. Taking him by the wings, I pushed him into the fissure by which he is naturally supposed to enter without persuasion. $\mathrm{He}$ was soon within the sac, and the inflexed wings of

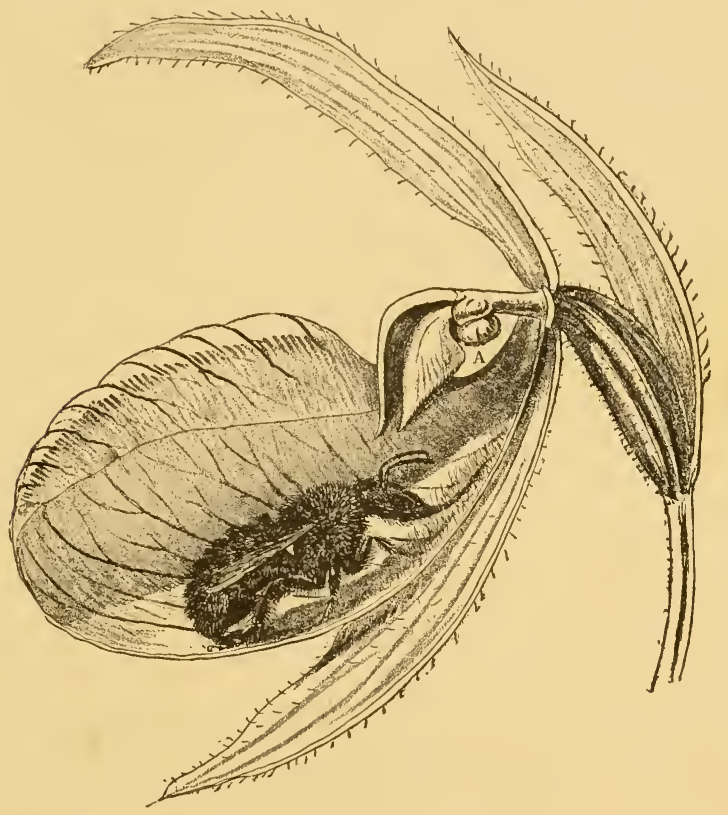

FIG. 3 .

the margin had closed above him, as shown in section, Fig. 2. He is now enclosed in a luminous prison, and his buzzing protests are audible and his vehemence visible from the outside of the sac. Let us suppose that he at length has become reconciled 
to his condition, and has determined to rationally fulfil the ideal of his environment, as he may, perhaps, have already done voluntarily before. The buzzing ceases, and our bee is now finding sweet solace for his incarceration in the copious nectar which he finds secreted among the fringy hairs in the upper narrowed portion of the flower, as shown at Fig. 3.

Having satiated his appetite, he concludes to quit his close quarters. After a few moments of more vehement futile struggling and buzzing, he at length espies, through the passage above the nectary fringe, a gleaming light, as from two windows (A). Toward these he now approaches. As he advances, the passage becomes narrower and narrower, until at length his back is brought against the overhanging stigma (Fig. 4). So narrow is the pass at this point that the efforts of the bee are distinctly manifest from the outside in the distension of the part and the consequent slight change in the droop of the lip. In another moment he has passed this ordeal, and his head is seen protruding from the window-like opening (A) on one side of the column. But his struggles are not yet ended, for his egress is still slightly checked by the narrow dimensions of the opening, and also by the detention of 


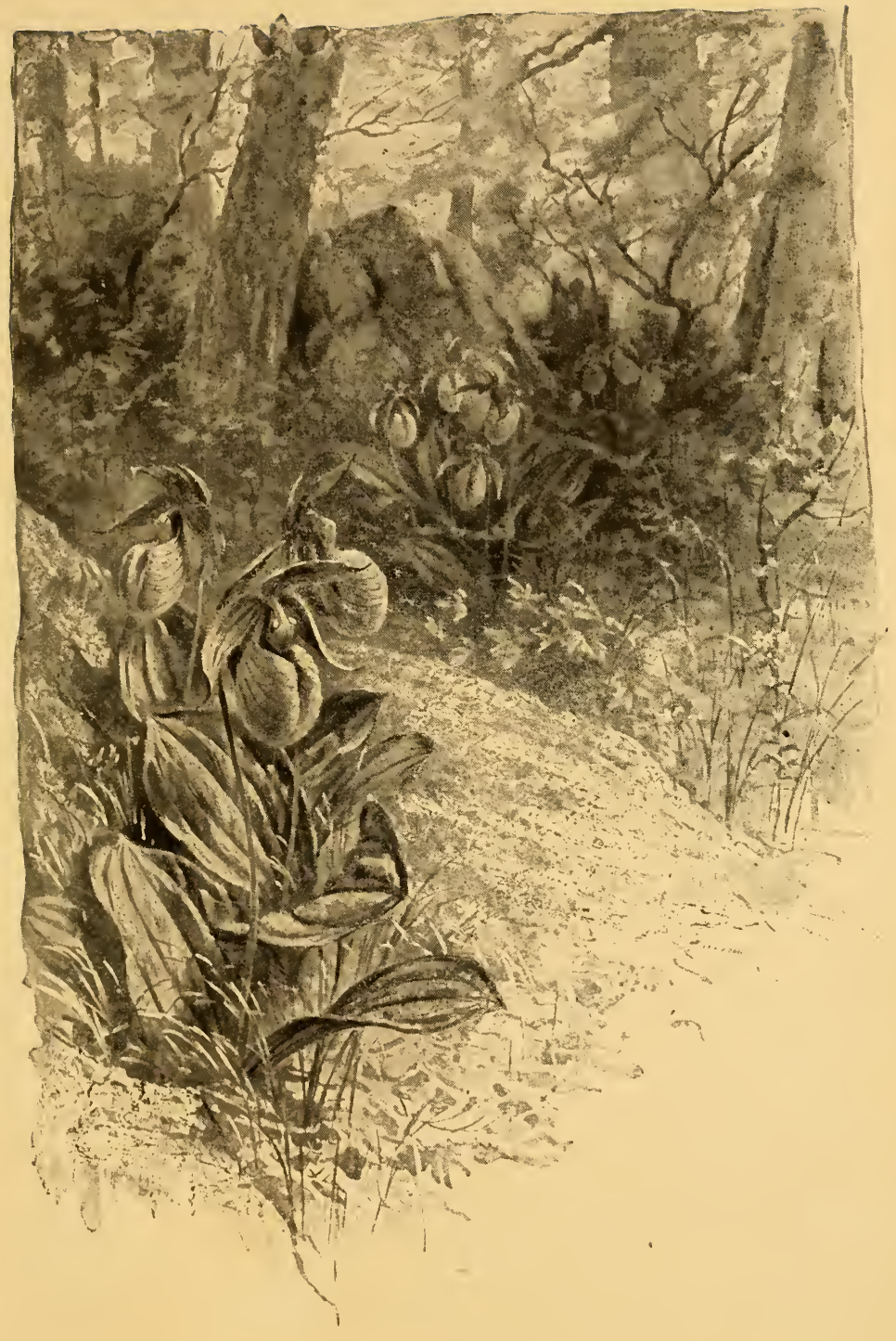




\section{Blossom Hosts and Insect Guests}

the anther, which his. thorax has now encountered. A strange etiquette this of the cypripedium, which speeds its parting guest with a sticky plaster smeared all over its back. As the insect works its way beneath the riscid contact, the anther is seen

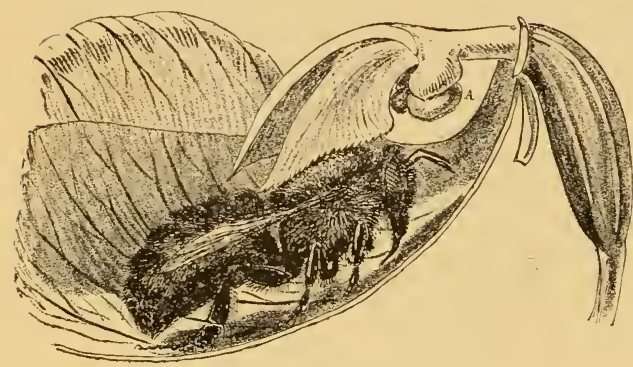

FIG. 4. to be drawn outward upon its hinge, and its yellow contents are spread upon the insect's back (Fig. 5), verily like a plaster.

Catching our bee before he has a chance to escape with his generous floral compliments, we unceremoniously introduce him into another cypripedium blossom, to which, if he were more obliging, he would naturally fly. He loses no time in profiting by his past experience, and is quickly creeping the gauntlet, as it were, or braving the needle's eye of this narrow passage. His pollensmeared back is soon crowding beneath the overhanging stigma again, whose forward-pointed papillae scrape off a portion of it (Fig. 4), thus insuring the cross-fertilizing of the flower, the bee receiving a fresh effusion of cypripedium 


\section{The Moccasill-Flower}

compliments piled upon the first as he says "goodby." It is doubtful whether in his natural life he ever fully effaces the telltale effects of this demonstrative an revoir.

Such, with slight modifications, is the plan evolved by the whole $\mathrm{cy}$ pripedium tribe. Darwin mentions bees as the implied fertilizers, and

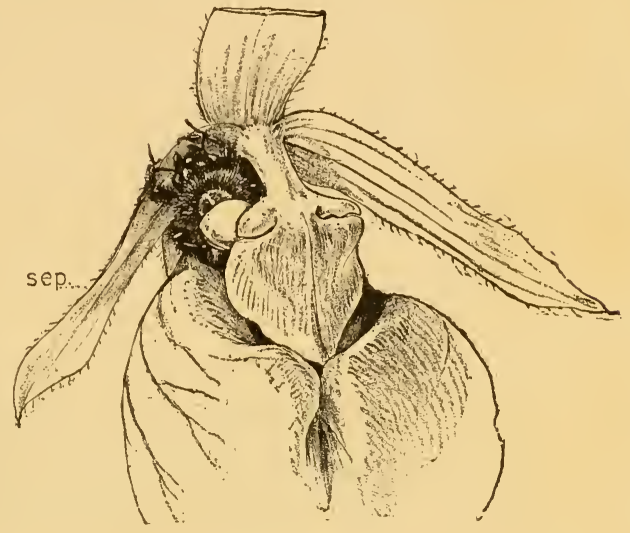

FIG. 5. doubtless many of the smaller bees do effect crossfertilization in the smaller species. But the more ample passage in acaule would suggest the mediumsized Bombus as better adapted.

The large yellow lady's-slipper or whip-poorwill's shoe, C. hirsutum, is fond of swampy woodlands. It has a peculiar, rather disagrecable, oily odor, which might lead one to suppose that flies fertilize it. Darwin, however, whom Professor Asa Gray interested in this species, found that small bees were more serviceable.

The smaller variety of the yellow lady's-slipper, 


\section{Blossom Hosts and Insect Gulests}

C. parviflorum, has a delightfully delicate fragrance ; the coloring, too, is deeper than that of its congener. In all other respects, the two species are nearly identical.

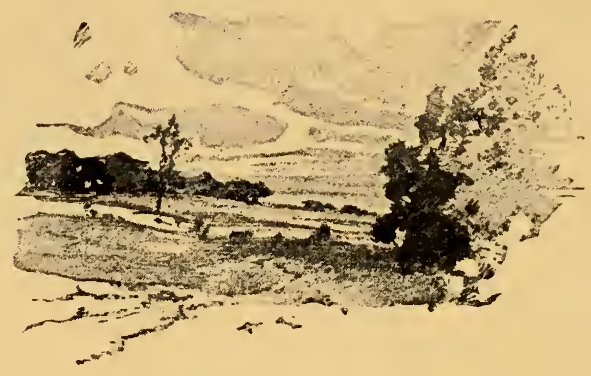




\section{Nature's Inexhaustible \\ Treasures}

TuE method of fertilization of each one of our fifty native orchids, though based upon one of the foregoing plans, affords its new surprise in its special modification in adaptation to its insect sponsor - all these various shapes, folds of petals, positions, colors, the size, length, and thickness of nectary, the relative positions of pollen and stigma, embodying an expression of welcom?, to the insect with which its life is so marvellously linked.

There are similar mysteries to those we have penetrated concealed within the heart's of many other of our most common wild flowers, and it is one of the most inspiring fascinations of Nature-study that, while rewarding her devotees with a full measure of her confidence, she still allures them on with an inexhaustible reserve. You may discover some unknown flower, dissect and analyze its parts, and find its place among the genera and species of vegetation; but there are strange testimonies beneath its conformation that are still unheeded, even as in 


\section{Blossom Hosts and Insect Guests}

these curious orchids, known and classified long ere Darwin sought the secret of their wondrous forms.

We cannot all be scientists or explorers, but we can at least learn to lend an answering, intelligent welcome to those little faces that smile at us from among the grass and withered leaves, that crowd humbly about our feet, and are too often idly crushed beneath our heel. The darkest pathless forest is relieved of its gloom to him who can nod a greeting with every footstep; who knows the pale dicentra that nods to him in return; who can call by name the peeping lizard among the moss, the pale white pipe among the matted leaves, or even the covering mould among the damp débris.

And to him who knows the arcana beneath a stone; who has learned with reverence how the clover goes to sleep, how the fireweed spins its silken floss, or how the spider floats its web from tree to tree; who has seen the brilliant cassida, the palpitating gem upon the leaf, change from burnished gold to iridescent pearl, or has watched the wondrous resurrection of the imago bursting from its living tomb-to such a one there is in all the length and breadth of Nature no such thing as exile, no 


\section{Nature's Inexhaustible Treasures}

such thought as loneliness and it were the voice of an unknown sentiment which should declare that

"A primrose by a river's brim

A yellow primrose was to him, And it was nothing more."

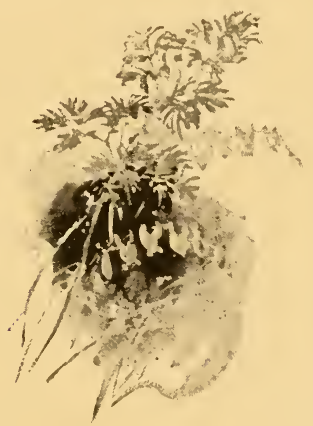





\section{INDEX}

A

PAGE

Acclepias cornuta (Common milkweed) ............... 97

Adder's-tongue, Yellow (E. Americanum)............... I23

Agents employed by natui 2 in transferring pollen from flower

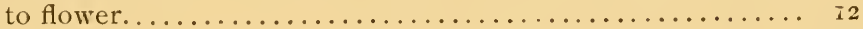

"All down the loose-walled lanes in archin' bowers"........ 37

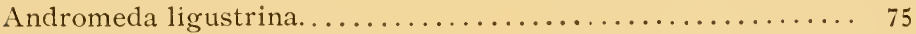

Angræcum, The great............................ 28

Anther, position and contents of .................... 3

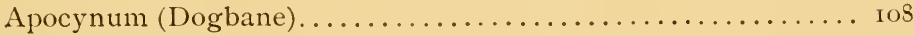

Arethusa bulbosa ............................ ${ }_{151}$

Arisæma triphyllum (Jack-in-the-pulpit, or Indian turnip)..... II I

Arnold, Sir Edwin, quotation from................... I

Arum, The .................................. Iog

\section{B}

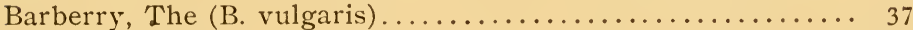

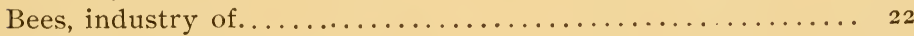

Beggar's-tick (D. accuminatus) .................... 45

Bermuda lily (L. Harrisi)........................ I 22

Blair, Patrick, theory regarding honey................ 6

Blazing-star (C. luteum).......................... I I9

Blue-flag (I. versicolor).......................... II 5

Bluets (H. cærulea), The riddle of the............... 6I

Botanists, The discoveries of four great............... 8

Botany, comparison between new and old............. I

the enchanted world of ........................ I

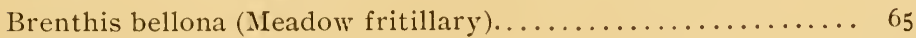

Brown-eyed Susan (R. hirta)..........................67 67 


\section{Index}

C

PAGE

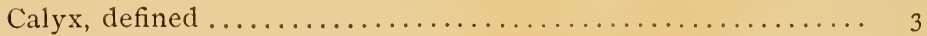

Canada lily (L. Canadense)..................... I20

Chamælirium luteum (Devil's-bit) ................. I I9

Cleistogamous bud of the violet described.............. I 7

buds sometimes hidden below ground............. I 7

- flowers an economical provision of nature.......... I 7

Clover, Red (T. pratense)......................... 43

Collinsonia Canadense (Horse-balm) ................ 94

Color preferences of various insects................ 23

— result of adaptation to insects . . . . . . . . . . . . . 8

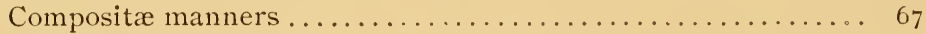

Corolla, defined................................. 3

Cross-fertilization, a direct advantage to the flower......... I3

— - agents employed by nature to effect........... I2

- method explained by Darwin............... I2

- - theory ............................

- universality of this method in nature........... I7

Cross-fertilized flowers the result of natural selection........ I3

Cypripedium acaule (Moccasin-flower) ............... I 58

- hirsutum (Large yellow lady's-slipper)............. I65

— parviflorum (Smaller yellow lady's-slipper)........... I66

\section{D}

Dandelion, self-fertilizing resource of. ............. 32

Darwin's revelations regarding flower fertilization.......... II

theory of fertilization tested by existing facts......... I3

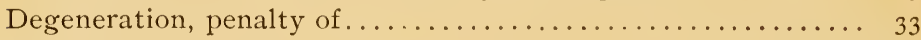

Desmodium accuminatus (Beggar's-tick) .............. 45

Devil's-bit (C. luteum)........................ I I9

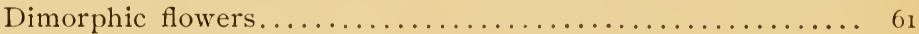

Dogbane (Apocynum) .......................... ros

Dog-tooth violet (E. Americanum) ................. 123

\section{E}

Evening primrose, The (E. biennis)............... 49

—— "A primrose by the river's brim"............. I69

—_ "A tuft of evening primroses".............. 50

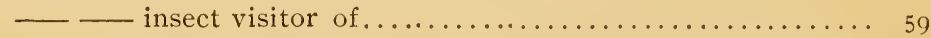


Evening primrose, The, moth that destroys its bud. . . . . . . 56

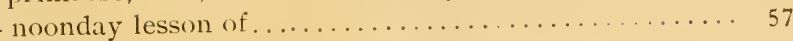

"The worm i' the bud"................... $5+$

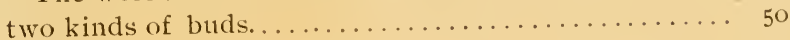

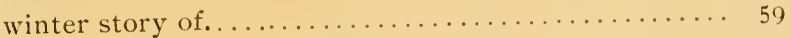

Evolution, period of time necessary for its work.......... 24

\section{F}

Families of flowers, how far their methods of fertilization are

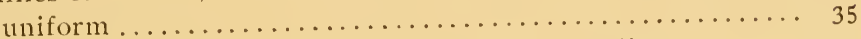

Fertilization, inference of early authorities regarding....... 5

Figwort, The (Scrophularia). . . . . . . . . . . . . . . . . . 79

Fire lily (L. Philadelphicum) . . . . . . . . . . . . . . . I I

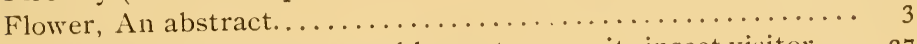

A, how its shape may enable one to name its insect visitor... . 27

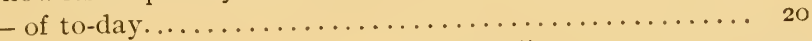

- significance of its position on the stalk........... 27

Flowering and non-flowering plants, varying laws governing

their fertilization......................... I 7

Flowering plants all subject to the law of cross-fertilization... I 8

Flowers, certain, invariably self-fertilized............... I6 dimorphic............................. 6r

evil-smelling, adapted to carrion-loving flies........... 8

heterostyled............................ 6I

- how they protect themselves from creeping pilferers...... 23

- methods of preventing self-fertilization.............. S-Io

- reasons which tend to make certain insects true to certain

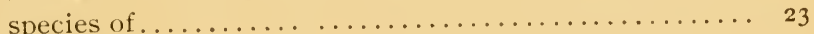

two-formed . . . . . . . . . . . . . .

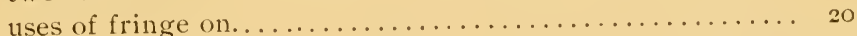

- variations of sometimes indicate the beginning of a new

species................................... 34

— varying degrees of adaptation to insects............ 15

Fragrance, result of adaptation to insects................ $s$

\section{G}

Genista tinctoria (Woad-waxen). ........................... 47

Ginseng, its cleistogamous buds................... I 7

"Gold-barred butterflies" ...................... I9 
Goodyera (Rattlesnake-plantain).................. I 45

Grew, Nehemias, explains the relation of stamens and pistils.. 3 how far correct in his theory of flower fertilization... 6

\section{$\mathbf{H}$}

Habenaria flava (Small pale green orchis).............. I 39

— lacera (Ragged orchid)................... 136

_ orbiculata (Great round-leaved or Great green orchis).... I I I

— psycodes (Purple-fringed orchid)................ I 35

Ifeath family, The $\ldots \ldots \ldots \ldots \ldots \ldots \ldots \ldots \ldots \ldots \ldots \ldots \ldots \ldots \ldots \ldots \ldots \ldots \ldots$

Heterostyled flowers. .......................... 6I

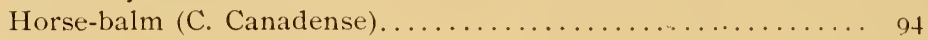

Houstonia cærulea (Bluets) . . . . . . . . . . .

\section{I}

Indian turnip (A. triphyllum).................. II

Insect fertilization of flowers, theory of propounded by Sprengel, 7

Insects, How the flowers woo the ................. I9

Iris versicolor (Blue-flag) ..................... II 5

- how it suffers from pilferers................. IIS

$\mathbf{J}$

Jack-in-the-pulpit (A. triphyllum)................. III

- how it entraps its visitors........... II2

K

Kalmia latifolia (Mountain laurel)................. 7 I

Krunitz, his theory regarding honey................. 6

L

Lady's-slipper (C. hirsutum) .................... I65

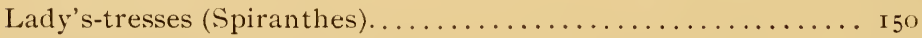

Lilium Canadense (Canada lily).................. I 20

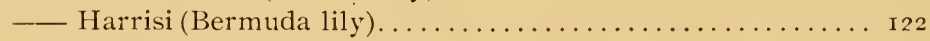

Philadelphicum (Fire lily).................. I 2 I

Lily family ........................... I

Linnæus, confirms Grew's theory...................... 5

- theory of flower fertilization, how far correct......... 6

— puzzled regarding functions of honey............. 6 
PAGE

Loosestrife. Purple (L. salicaria)................... 66

Lucerne, The (M. sativa)..................... 46

Lythrum salicaria (Purple loosestrife)............... 66

\section{M}

Madder family, The......................... 6 I

Meadow fritillary (Brenthis bellona $) \ldots \ldots \ldots \ldots \ldots \ldots \ldots \ldots \ldots . . \ldots 6_{5}$

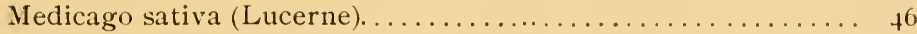

Milkweed, Common (A. cornuta)................... 97

- how it entraps its benefactors............... I03

Mint family, The.......................... 9 I

Moccasin-flower (C. acaule). . . . . . . . . . . . . . . .

Moth that destroys the Evening primrose buds . . . . . . . . $5^{6}$

that fertilizes the Evening primrose............. 58

Mountain laurel, The $(\mathrm{K}$. latifolia).................

N

Natural selection, conditions under which it works......... 34

how it perfects the flowers. .................... I 3

how it works in adapting flower and insect........... 24

Nature's frugality. ........................ 34

inexhaustible treasures.................... I67

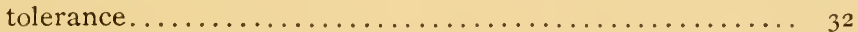

Nectar, laws governing its secretion.................. 24

result of adaptation to insects. ................. 8

Nectaries, work of natural selection in developing......... 22

Nectary riddles and their explanation. ............... 2 I

Non-flowering plants. ..................... I 7

\section{O}

Enothera biennis (Evening primrose) ................ 49

Orchid, An, defined......................... I 26

blossoms, how they differ from other flowe:s. . . . . . . . I 25

Large round-leafed $(H$. orbiculata $) \ldots \ldots \ldots \ldots \ldots \ldots \ldots$ I I

Purple-fringed (H. psycodes). . . . . . . . . . . . . . I I 35

Ragged (H. lacera). ...................... I36

Showy (O. spectabilis)......................... I 29

Orchids, adaptations to eyes, tongues, etc., of insects....... I34 columns of ....................... 27 


\section{Index}

PAGE

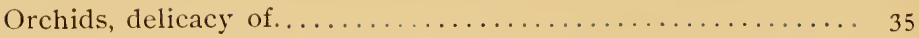

seed-pods of. ....................... I 28

Orchis, Great green (H. orbiculata) ............... I

morio ....................... 7

nectar, how concealed. . ................. 8

reason for peculiar concealment of nectar........ 27

Tubercled, or Small pale green (H. flara)............. I 39

Oxalis (Wood-sorrel) . . . . . . . . . . . . . . . . . . 66

\section{P}

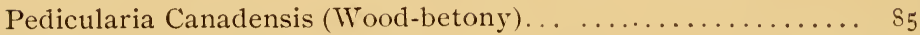

Pickerel weed, Blue $(P$. cordata)..................... 66

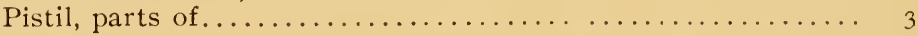

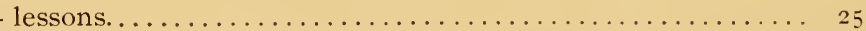

Pogonia, Sweet or Grass-pink (P. ophioglossoides)........... I 55

Pollen, functions of ....................

Pollination, see Fertilization.

Polygala, its cleistogamous buds................. I6

Pontidera, his theory regarding honey............... 6

Pontidera cordata (Blue pickerel weed)................ 66

Primrose, see Evening primrose.

Progress Nature's law. ........................ 33

Pulse family, The.......................... 43

Purple-fringed orchid (H. psycodes)................ I35

Purple loosestrife (L. salicaria). ................... 66

Q

Quaker-ladies (H. cærulea)................... 6I

$\mathbf{R}$

Rattlesnake-plantain, The (Goodyera)................. I 45

Rudbeckia hirta (Brown-eyed Susan)................. 67

\section{S}

Sage, The (S. officinalis) . . . . . . . . . . . . .

Scrophularia (Figwort)......................... 79

"Secrets of Nature in Forms and Fertilization Discovered, The," 6

Self-fertilization, conditions preventing............ S-IO-I2

Sham nectar-producers, note.................. 7 
"Shein saft blumen".

Skunk-cabbage (S. foetidus).

—— destructive to insect life................... 1

Speculations, Early, regarding the functions of honey...... 5

Spiranthes (Lady's-tresses) . . . . . . . . . . . . . . . 150

Sprengel, Conrad, announces that flowers are fertilized by insects ............................. 7

begins his investigations................. 6

process of flower fertilization suggested by.......

"Secrets of Nature in Forms and Fertilization Discovered ".......................... 6

weak points in his theory of flower fertilization...... 7,8 where his errors lay...................... II

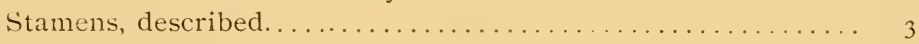

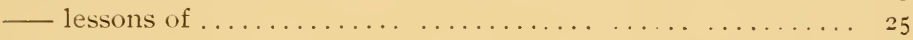

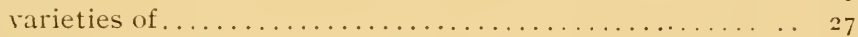

Stigma, must receive pollen in order to mature fruit........ +

Survival of the fittest, law of, see Natural selection.

Symplocarpus fœtidus (Sktuk-cabbage) . . . . . . . . . . . I I 2

$\mathrm{T}$

Tineidæ moth................................... 56

Trifolium pratense (Red clover) ................... +3

Trout lily (E. Americanum) .................... I 23

\section{V}

Variation, tendency to, in individual flowers............. It

Variations in flowers sometimes indicative of the beginning of

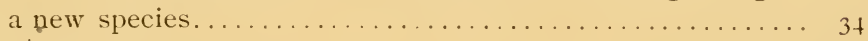

Violet, The ............................. I6

its cleistogamous buds . . . . . . . . . . . . . I6

\section{W}

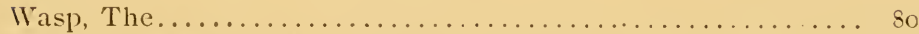

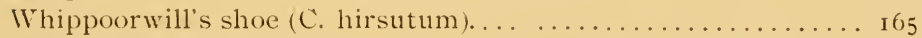

Woad-waxen (G. tinctoria) ....................... 47

IVood-betony, The (P. Canadense) .................. $8_{5}$

IVood-sorrel (Oxalis). ........................... 66 



\section{SUPPLEMENT}

The following tables give the botanical name, insect visitor, method, if any, of preventing or limiting self-fertilization,* and varions other facts for about two hundred and fifty species of our native wild flowers. This matter is intended only to indicate the lines along which personal investigation may be carried on, as it is impossible with the scanty data at present available on this subject, to compile anything exhaustive or final. Gray's classification has been followed.

In supplying the information given under the head of "Insect Visitors," the olject in view has been to give the insects best arlapted to serve the needs of the flowers, not to give a complete list of all the insects that may at various times visit them. The names of the less important insects as well as their scientific names, where given, are enclosed in brackets.

* The later writers make a distinction between "fertulization" and "pollmation." "Pollination" is userl to signify the transfer of pollen from anther to stigma, while "fertilization" is molerstood to mean the mion of the nucleus of the pollen grain with the nucleus of the ovule. This technical distmetion, for various reasons, it has not been thought necessary to observe in the present volume, the terms being used interchangeably. 


\section{Crowfoot Family (Ranunculàceae)}

\begin{tabular}{|c|c|c|c|}
\hline COMMON NAME & $\begin{array}{l}\text { SCIENTIFIC } \\
\text { NAME }\end{array}$ & $\begin{array}{l}\text { INSECT } \\
\text { VISITORS }\end{array}$ & $\begin{array}{l}\text { METHOD OF PREVENT- } \\
\text { INAOR LIMITINGSELF- } \\
\text { FERTILIZATION, ETC. }\end{array}$ \\
\hline $\begin{array}{l}\text { Virgin's Bower, } \\
\text { or Virginia } \\
\text { Clematis }\end{array}$ & $\begin{array}{l}\text { Clématis } \\
\text { Virginıàna }\end{array}$ & $\begin{array}{l}\text { Flies and short- } \\
\text { tonguted bees }\end{array}$ & $\begin{array}{l}\text { Stigmatic flowers gener- } \\
\text { ally separate from stam- } \\
\text { mate flowers. }\end{array}$ \\
\hline $\begin{array}{l}\text { Liver-leaf, or } \\
\text { Hepatica }\end{array}$ & $\begin{array}{l}\text { Hepática } \\
\text { triloba }\end{array}$ & $\begin{array}{l}\text { Pollen-collecting } \\
\text { bees and flies } \\
\text { (beetles) }\end{array}$ & $\begin{array}{l}\text { Some flowers perfect, oth- } \\
\text { ers stigmatic, and oth } \\
\text { ers staminate. Perfect } \\
\text { flowers frequently self } \\
\text { fertilized. }\end{array}$ \\
\hline $\begin{array}{l}\text { Sharp-lobed } \\
\text { Hepatica }\end{array}$ & $\begin{array}{l}\text { Hepática } \\
\text { acutíloba }\end{array}$ & Bees and flies & $\begin{array}{l}\text { Stigmatic flowers some- } \\
\text { times separate fron } \\
\text { stammate ones. }\end{array}$ \\
\hline $\begin{array}{l}\text { Windilower, or } \\
\text { Wood Anemone }\end{array}$ & $\begin{array}{l}\text { Anemòne } \\
\text { nemoròsa }\end{array}$ & $\begin{array}{l}\text { Bees, beetles, } \\
\text { and flies }\end{array}$ & $\begin{array}{l}\text { Self-fertilization probably } \\
\text { quite frequent. }\end{array}$ \\
\hline $\begin{array}{l}\text { Tall Meadow } \\
\text { Rue }\end{array}$ & $\begin{array}{l}\text { Thalictrum } \\
\text { çornuti }\end{array}$ & Many insects & $\begin{array}{l}\text { Some flowers perfect, oth- } \\
\text { ers staminate, others } \\
\text { stigmatic. }\end{array}$ \\
\hline $\begin{array}{l}\text { Conmon Mead- } \\
\text { ow Buttercup, } \\
\text { or } \\
\text { Tall Crowfoot }\end{array}$ & $\begin{array}{l}\text { Ranúneulus } \\
\text { acrís }\end{array}$ & 60 species noted & \\
\hline $\begin{array}{l}\text { White } \\
\text { Baneberry }\end{array}$ & $\begin{array}{l}\text { Actæ̃a } \\
\text { álba }\end{array}$ & $\begin{array}{c}\text { Female bees } \\
\text { (Halictus) }\end{array}$ & $\begin{array}{l}\text { Tendency toward matur- } \\
\text { ing stigma before an- } \\
\text { thers. }\end{array}$ \\
\hline $\begin{array}{l}\text { Black Cohosh, } \\
\text { or } \\
\text { Tall Bugbane }\end{array}$ & $\begin{array}{l}\text { Cimicífuga } \\
\text { racemòsa }\end{array}$ & $\begin{array}{l}\text { Pollen-gathering } \\
\text { flies }\end{array}$ & \\
\hline $\begin{array}{l}\text { Marsh Marigolel, } \\
\text { or } \\
\text { Amer. Cowslıp }\end{array}$ & $\begin{array}{l}\text { Cáltha } \\
\text { palústris }\end{array}$ & $\begin{array}{l}\text { Bees and flies } \\
\text { (beetles and } \\
\text { butterflies) }\end{array}$ & Anthers open outward. \\
\hline $\begin{array}{l}\text { Gold-thread, } \\
\text { or } \\
\text { Canker Root }\end{array}$ & $\begin{array}{l}\text { Cóptis } \\
\text { trifolia }\end{array}$ & $\begin{array}{c}\text { Gnats and } \\
\text { beetles }\end{array}$ & \\
\hline Wild Columbine & $\begin{array}{l}\text { Aquilègia } \\
\text { Canadénsis }\end{array}$ & $\begin{array}{l}\text { Bumblebees and } \\
\text { lummmingbirds }\end{array}$ & $\begin{array}{l}\text { Anthers mature before } \\
\text { stigma. Flower has lost } \\
\text { the power of self-ferti- } \\
\text { lization. }\end{array}$ \\
\hline $\begin{array}{l}\text { European, or } \\
\text { Common Garden } \\
\text { Columbine }\end{array}$ & $\begin{array}{l}\text { Aquilègia } \\
\text { vulgàris }\end{array}$ & $\begin{array}{l}\text { Bumblebees, } \\
\text { long-lipped bees, } \\
\text { long-tongued } \\
\text { bees }\end{array}$ & $\begin{array}{l}\text { Some anthers mature be- } \\
\text { fore stigmas. }\end{array}$ \\
\hline $\begin{array}{l}\text { Field, or } \\
\text { Branched } \\
\text { Larkspur }\end{array}$ & $\begin{array}{l}\text { Delphínium } \\
\text { Coilsólida }\end{array}$ & $\begin{array}{l}\text { Bumblebees and } \\
\text { butterflies }\end{array}$ & $\begin{array}{l}\text { Anthers mature and with- } \\
\text { er before stigmas are } \\
\text { mature. Flower has lost } \\
\text { power of self-fertiliza- } \\
\text { tion. }\end{array}$ \\
\hline $\begin{array}{l}\text { Tall Wild } \\
\text { Larkspur }\end{array}$ & $\begin{array}{l}\text { Delphínium } \\
\text { exaltàtum }\end{array}$ & Bumblebees & $\begin{array}{l}\text { Anthers mature before } \\
\text { stigma. }\end{array}$ \\
\hline
\end{tabular}

\section{Magnolia Family (\&Magnoliaceàe)}

\begin{tabular}{|c|c|c|c|}
\hline $\begin{array}{c}\text { Laurel, or } \\
\text { Small Magnolia }\end{array}$ & $\begin{array}{l}\text { Mąunòlia } \\
\text { glaùca }\end{array}$ & Beetles & $\begin{array}{l}\text { Stigma matures } \\
\text { anthers. }\end{array}$ \\
\hline
\end{tabular}




\section{Barberry Family (Berberidaceae)}

\begin{tabular}{|c|c|c|c|}
\hline COMMON NAME & $\begin{array}{c}\text { SCIFNTIFIC: } \\
\text { NAME }\end{array}$ & $\begin{array}{l}\text { INSECT } \\
\text { VISITORS }\end{array}$ & $\begin{array}{l}\text { METIOH OF PREVENT } \\
\text { INGOH LIMITING SELF- } \\
\text { FERTILIZATION, ETC. }\end{array}$ \\
\hline $\begin{array}{l}\text { Common } \\
\text { Barberry }\end{array}$ & $\begin{array}{l}\text { Berberis } \\
\text { vulgaris }\end{array}$ & $\begin{array}{l}\text { Bees } \\
\text { (beetles and } \\
\text { flies) }\end{array}$ & $\begin{array}{l}\text { I'ollen concealed in boxes } \\
\text { stamens liberated by th } \\
\text { insect. Self-fertilization } \\
\text { not probable. See text }\end{array}$ \\
\hline
\end{tabular}

\section{Water-lily Family (Nymphaeaceae)}

\begin{tabular}{|c|c|c|c|}
\hline $\begin{array}{l}\text { Yellow Nelumbo, } \\
\text { or } \\
\text { Water climquepin }\end{array}$ & $\begin{array}{l}\text { Nelumbo } \\
\text { lutteum }\end{array}$ & $\begin{array}{l}\text { Small bees, flies, } \\
\text { and beetles }\end{array}$ & $\begin{array}{l}\text { Stigma matures before } \\
\text { anthers }\end{array}$ \\
\hline $\begin{array}{c}\text { Sweet scented } \\
\text { White Water Lily } \\
\text { or Pond Jily }\end{array}$ & $\begin{array}{c}\text { Nymphaèa } \\
\text { odoràta }\end{array}$ & $\begin{array}{l}\text { Pollen-gathering } \\
\text { bees and flies } \\
\text { (beetles) }\end{array}$ & Self-fertilization possible \\
\hline $\begin{array}{c}\text { Large Yellow } \\
\text { Pond or } \\
\text { Watel Jily }\end{array}$ & $\begin{array}{l}\text { Nìpliar } \\
\text { ádvena }\end{array}$ & $\begin{array}{l}\text { Small bees, flies, } \\
\text { and beetles }\end{array}$ & $\begin{array}{l}\text { Stigma matures } \\
\text { anthers }\end{array}$ \\
\hline
\end{tabular}

\section{Poppy Family (Papaveraceae)}

\begin{tabular}{l|l|l|l} 
Blood root & $\begin{array}{l}\text { Sauguinàia } \\
\text { Canadiensis }\end{array}$ & $\begin{array}{c}\text { Short-tongued } \\
\text { bees and flies }\end{array}$ & $\begin{array}{c}\text { Stigma matures before } \\
\text { anthers }\end{array}$ \\
\end{tabular}

\section{Fumitory Family (Fumariaceae)}

\begin{tabular}{c|c|c|c|}
$\begin{array}{c}\text { Dutchman's } \\
\text { Breeches, or } \\
\text { White Hearts }\end{array}$ & $\begin{array}{c}\text { Dicéntra } \\
\text { cuenllària }\end{array}$ & $\begin{array}{c}\text { long-tongued } \\
\text { female bumble- } \\
\text { bees }\end{array}$ & $\begin{array}{c}\text { Anthers mature before } \\
\text { stigmas }\end{array}$ \\
\cline { 1 - 2 } Pale Corydalis & $\begin{array}{c}\text { Corýlalis } \\
\text { glauca }\end{array}$ & $\begin{array}{c}\text { Pollen-collecting } \\
\text { bees, also humble- } \\
\text { bees seekiug } \\
\text { nectar }\end{array}$ &
\end{tabular}

\section{Mustard Family (Cruciferae)}

\begin{tabular}{|c|c|c|c|}
\hline $\begin{array}{c}\text { Field or } \\
\text { Corn IIustard }\end{array}$ & $\begin{array}{c}\text { Brassiea Sinàpis } \\
\text { arvénsis }\end{array}$ & Bees and flies & $\begin{array}{l}\text { Anthers rotate away from } \\
\text { stig ma. Self-fertiliza- } \\
\text { tion possible }\end{array}$ \\
\hline $\begin{array}{l}\text { Ladies' Smock, } \\
\text { or } \\
\text { Cuckoo-flower }\end{array}$ & $\begin{array}{l}\text { Cardamine } \\
\text { praténsis }\end{array}$ & Mauy insects & $\begin{array}{l}\text { Anthers rotate away from } \\
\text { stigma. Self-fertiliza- } \\
\text { tion possible }\end{array}$ \\
\hline $\begin{array}{l}\text { Bulbous, or } \\
\text { spring Cress }\end{array}$ & $\begin{array}{l}\text { Caulamine } \\
\text { rhomboidea }\end{array}$ & $\begin{array}{l}\text { Bees, flies, butter- } \\
\text { ilies, etc. (Andrena } \\
\text { and Halictns) }\end{array}$ & $\begin{array}{l}\text { Stamens revolve away } \\
\text { from stigma. Self-ferti- } \\
\text { lization possible }\end{array}$ \\
\hline $\begin{array}{l}\text { Two-leaved } \\
\text { Tooth-wort, or } \\
\text { Crinkle-root }\end{array}$ & $\begin{array}{l}\text { Dentaria } \\
\text { diphýlla }\end{array}$ & $\begin{array}{l}\text { Pollen-collecting } \\
\text { bees (Andrena and } \\
\text { Ilalictus) }\end{array}$ & \\
\hline Whitlow grass & $\begin{array}{l}\text { Dràba } \\
\text { vélna }\end{array}$ & $\begin{array}{c}\text { Pollen-collecting } \\
\text { bees }\end{array}$ & $\begin{array}{l}\text { Self-fertilization very } \\
\text { common }\end{array}$ \\
\hline $\begin{array}{l}\text { Shepherd's } \\
\text { Purse }\end{array}$ & $\begin{array}{c}\text { Capsella } \\
\text { Bursa-pastòris }\end{array}$ & $\begin{array}{l}\text { Flies (Syrphidie } \\
\text { and Muscida) }\end{array}$ & $\begin{array}{l}\text { Self-fertilization very } \\
\text { common }\end{array}$ \\
\hline
\end{tabular}




\begin{tabular}{|c|c|c|c|}
\hline \multicolumn{4}{|c|}{ Supplenent } \\
\hline \multicolumn{4}{|c|}{ Violet Family (Violaceae) } \\
\hline COMnON NAME & $\begin{array}{l}\text { SCIENTIFIC } \\
\text { NAME }\end{array}$ & $\begin{array}{l}\text { INSE('T } \\
\text { VISITORS }\end{array}$ & $\begin{array}{l}\text { METHOD OF PRFYENT- } \\
\text { ING OR LINITING SELF- } \\
\text { FERTILIZATION, ETC. }\end{array}$ \\
\hline $\begin{array}{l}\text { Arrow-leaved } \\
\text { Violet }\end{array}$ & $\begin{array}{l}\text { Viola } \\
\text { sagittàta }\end{array}$ & Bees & $\begin{array}{l}\text { Showy flowers cross fer- } \\
\text { tilized. Depends largely } \\
\text { for the propagation of } \\
\text { its kind upon cleisto- } \\
\text { gamous buds }\end{array}$ \\
\hline$\underset{\text { Violet }}{\text { Common Blue }}$ & $\begin{array}{l}\text { Viola } \\
\text { cucullata }\end{array}$ & $\begin{array}{l}\text { Small pollen-col- } \\
\text { lecting bees (Os- } \\
\text { mas) (bumble- } \\
\text { bees, butterflies) } \\
\end{array}$ & $\begin{array}{l}\text { Stigma remote from an- } \\
\text { ther, but self-pollination } \\
\text { possible }\end{array}$ \\
\hline$\underset{\text { Varly Blne }}{\text { Violet }}$ & $\begin{array}{l}\text { Vìola } \\
\text { palmàta }\end{array}$ & $\begin{array}{c}\text { Bees and } \\
\text { butterflies }\end{array}$ & $\begin{array}{l}\text { Protruding stigma strikes } \\
\text { incoming bee Pollen } \\
\text { liberated, by the jar of } \\
\text { insect's eontaet with the } \\
\text { stigma, from the antlier }\end{array}$ \\
\hline $\begin{array}{c}\text { Bird-foot } \\
\text { Violet }\end{array}$ & $\begin{array}{l}\text { Vìola } \\
\text { pedàta }\end{array}$ & $\begin{array}{l}\text { Long-tonguedbees } \\
\text { and butterflies }\end{array}$ & \\
\hline $\begin{array}{c}\text { Sweet White } \\
\text { Violet }\end{array}$ & $\begin{array}{l}\text { Viola } \\
\text { blánda }\end{array}$ & Bees & \\
\hline $\begin{array}{l}\text { Primrose-leaved } \\
\text { Violet }\end{array}$ & $\begin{array}{l}\text { Viola } \\
\text { primulaefolia }\end{array}$ & $\because$ & \\
\hline $\begin{array}{c}\text { Lance-leaved } \\
\text { Violet }\end{array}$ & $\begin{array}{l}\text { Viola } \\
\text { laneeolàta }\end{array}$ & $" 6$ & \\
\hline $\begin{array}{c}\text { Canada } \\
\text { Violet }\end{array}$ & $\begin{array}{l}\text { Viola } \\
\text { Canadénsis }\end{array}$ & $" “$ & \\
\hline \multicolumn{4}{|c|}{ Rock-rose Family (Cistaceae) } \\
\hline $\begin{array}{l}\text { Long-branched } \\
\text { frostweed, or } \\
\text { Frost flower }\end{array}$ & $\begin{array}{l}\text { Helianthemum } \\
\text { Canadense }\end{array}$ & Mally insects & $\begin{array}{l}\text { Stamens lie flat to petals } \\
\text { well away from stigma }\end{array}$ \\
\hline \multicolumn{4}{|c|}{ St. John's-wort Family (Hypericaceae) } \\
\hline $\begin{array}{l}\text { Common } \\
\text { St. John's WVort }\end{array}$ & $\begin{array}{l}\text { Hypérieum } \\
\text { perforàtum }\end{array}$ & $\begin{array}{l}\text { Pollen-gathering } \\
\text { bees. Pollen-eat- } \\
\text { ing flies (Beetles) }\end{array}$ & $\begin{array}{l}\text { Self-fertilization very } \\
\text { common }\end{array}$ \\
\hline $\begin{array}{l}\text { Marsh } \\
\text { St. Johu's Wort }\end{array}$ & $\begin{array}{l}\text { Elòdes } \\
\text { Virgínica }\end{array}$ & $\begin{array}{l}\text { Pollen-gathering } \\
\text { bees. Pollen-eat- } \\
\text { ing flies (Beetles) }\end{array}$ & $\begin{array}{l}\text { Self-fertilization very } \\
\text { common }\end{array}$ \\
\hline \multicolumn{4}{|c|}{$\begin{array}{c}\text { Pink Family (Caryophyllaceae) } \\
\text { Subdivision Chickweed Family }\end{array}$} \\
\hline $\begin{array}{l}\text { Deptford - } \\
\text { Pink }\end{array}$ & $\begin{array}{l}\text { Diántlus } \\
\text { Armèria }\end{array}$ & Butterflies & Self-pollination probable \\
\hline Corn-cockle & $\begin{array}{l}\text { Lýehnis } \\
\text { Githàgo }\end{array}$ & $\begin{array}{c}\text { Moths, bees, flies, } \\
\text { butterflies }\end{array}$ & $\begin{array}{l}\text { Anthers mature before } \\
\text { stigma }\end{array}$ \\
\hline $\begin{array}{l}\text { Wild or Pink } \\
\text { Catchfly }\end{array}$ & $\begin{array}{c}\text { Silène } \\
\text { Pennsylvánica }\end{array}$ & $\begin{array}{c}\text { Bees, } \\
\text { butterflies }\end{array}$ & $\begin{array}{l}\text { Anthers mature before } \\
\text { stigmas, } 2 \text { sets of sta- } \\
\text { mens maturing at differ- } \\
\text { ent intervals, } 3 \text { styles }\end{array}$ \\
\hline $\begin{array}{l}\text { Fire } \\
\text { Pink }\end{array}$ & $\begin{array}{l}\text { Silène } \\
\text { Virgíniea }\end{array}$ & Butterflies & \\
\hline
\end{tabular}


Pink Family-Continued

\begin{tabular}{|c|c|c|c|}
\hline COMNON NAME & $\begin{array}{l}\text { SCIENTIFIC } \\
\text { NAME }\end{array}$ & $\begin{array}{l}\text { INSECT } \\
\text { VISITORS }\end{array}$ & $\begin{array}{l}\text { METHOH OF PREVENT- } \\
\text { INGOR LIMITINGSELF- } \\
\text { FERTIIIAATION, ETC. }\end{array}$ \\
\hline$\underset{\text { Starry }}{\text { Campion }}$ & $\begin{array}{l}\text { Silène } \\
\text { stellàta }\end{array}$ & $\begin{array}{l}\text { Noths and } \\
\text { butterflies }\end{array}$ & \\
\hline $\begin{array}{l}\text { Bladder } \\
\text { Campion }\end{array}$ & $\begin{array}{l}\text { Silène } \\
\text { inflàta }\end{array}$ & Moths & $\begin{array}{l}\text { Some flowers perfeet, otli- } \\
\text { ers staminate, and otli- } \\
\text { ers stigmatie, still otli- } \\
\text { ers mature anthers and } \\
\text { stigmas atdifferent peri- } \\
\text { ods }\end{array}$ \\
\hline $\begin{array}{c}\text { Soapwort, } \\
\text { or } \\
\text { Bouncing Bet }\end{array}$ & $\begin{array}{l}\text { Saponària } \\
\text { offieinàlis }\end{array}$ & $\begin{array}{l}\text { Sphinx Moth } \\
\text { Pollen-gathering } \\
\text { bees }\end{array}$ & $\begin{array}{l}\text { Anthers mature before } \\
\text { stigmas, } 2 \text { sets of sta- } \\
\text { mens maturing at differ- } \\
\text { ent intervals }\end{array}$ \\
\hline $\begin{array}{l}\text { Common } \\
\text { Chickweed }\end{array}$ & $\begin{array}{l}\text { Stellàriat } \\
\text { mèclia }\end{array}$ & $\begin{array}{l}\text { Simall bees } \\
\text { and flies }\end{array}$ & $\begin{array}{l}\text { IIas not lost the power of } \\
\text { self-fertilization, though } \\
\text { its anthers generally } \\
\text { mature before its stigma }\end{array}$ \\
\hline \multicolumn{4}{|c|}{ Purslane Family (Portulacaceae) } \\
\hline Spring Beauty & $\begin{array}{l}\text { Claytònia } \\
\text { Virgíniea }\end{array}$ & $\begin{array}{c}\text { Female bumble- } \\
\text { bees (flies, } \\
\text { butterflies) }\end{array}$ & $\begin{array}{l}\text { Anthers mature before } \\
\text { stigma }\end{array}$ \\
\hline \multicolumn{4}{|c|}{ Mallow Family (Malvaceae) } \\
\hline $\begin{array}{c}\text { Swamp Rose } \\
\text { Mallow } \\
\end{array}$ & $\begin{array}{c}\text { Hibíseus } \\
\text { Moscheutos } \\
\end{array}$ & Bumblebees & $\begin{array}{l}\text { Anthers mature before } \\
\text { stigma }\end{array}$ \\
\hline $\begin{array}{l}\text { Common or Romind- } \\
\text { leaved Mallow }\end{array}$ & $\begin{array}{l}\text { Málva rotundi- } \\
\text { fólia }\end{array}$ & Mainly bees & $\begin{array}{l}\text { Self-fertilization very } \\
\text { eommon }\end{array}$ \\
\hline High Mallow & $\begin{array}{c}\text { Málvat } \\
\text { sylvéstris }\end{array}$ & Many inseets & $\begin{array}{l}\text { Pistils radiate away from } \\
\text { stamens. Stamens ma- } \\
\text { ture first }\end{array}$ \\
\hline \multicolumn{4}{|c|}{ Geranium Family (Geraniaceae) } \\
\hline $\begin{array}{c}\text { Yellow Wood } \\
\text { Sorrel }\end{array}$ & Oxalis strícta & Bees & Self-pollination usual \\
\hline $\begin{array}{l}\text { White or True } \\
\text { Wood sorrel }\end{array}$ & $\begin{array}{l}\text { Óxalis } \\
\text { Acetosélla }\end{array}$ & Few insects & $\begin{array}{l}\text { Showy flowers incapable } \\
\text { of self-fertilization. Pro- } \\
\text { luces also eleistoga- } \\
\text { mous bucls }\end{array}$ \\
\hline $\begin{array}{c}\text { Violet IVood } \\
\text { sorrel }\end{array}$ & Gxalis violacea & simall bees & Dimorphic blossoms \\
\hline $\begin{array}{l}\text { Wild or Spotted } \\
\text { Geranim or } \\
\text { Crames bill }\end{array}$ & $\begin{array}{l}\text { Gerànium } \\
\text { maculàtum }\end{array}$ & Bees & $\begin{array}{l}\text { Anthers mature before } \\
\text { stigma }\end{array}$ \\
\hline $\begin{array}{l}\text { Herb Robert or } \\
\text { Red Robin }\end{array}$ & $\begin{array}{l}\text { Geràninm } \\
\text { Robertiànum }\end{array}$ & Flies & $\begin{array}{l}\text { Anthers mature before } \\
\text { stigma. Two sets of } \\
\text { stamens. Evil-smelling } \\
\text { flower }\end{array}$ \\
\hline $\begin{array}{l}\text { Spotted Touleh-me- } \\
\text { not or Jewel } \\
\text { weed }\end{array}$ & $\begin{array}{l}\text { Impàtiens } \\
\text { fúlva }\end{array}$ & $\underset{\text { birds }}{\text { Bees, humming }}$ & $\begin{array}{l}\text { stigma eoneealed beneatl } \\
\text { st a me ns. A nthers } \\
\text { mature first. Produces } \\
\text { also el e is tog a mous } \\
\text { buds. }\end{array}$ \\
\hline
\end{tabular}




\begin{tabular}{|c|c|c|c|}
\hline \multicolumn{4}{|c|}{ Supplomint } \\
\hline \multicolumn{4}{|c|}{ Cashew Family (Anacardiaceae) } \\
\hline ComMoN Name & $\begin{array}{l}\text { SCIENTIFIC } \\
\text { NAIE }\end{array}$ & $\begin{array}{l}\text { INSECT } \\
\text { VISITORS }\end{array}$ & $\begin{array}{l}\text { METHOD OF PREVENT- } \\
\text { INC OR LIMITING SELF- } \\
\text { FERTILIZATION, ETC. }\end{array}$ \\
\hline $\begin{array}{l}\text { Staghorn } \\
\text { Sumac }\end{array}$ & Rhús tỳphina & $\begin{array}{l}\text { Short-tongued } \\
\text { bees and flies }\end{array}$ & $\begin{array}{l}\text { Stigmatic flowers gener- } \\
\text { ally sepalate from stam- } \\
\text { inate ones }\end{array}$ \\
\hline \multicolumn{4}{|c|}{ Staff-tree Family (Celastraceae) } \\
\hline $\begin{array}{l}\text { (Climbing } \\
\text { Bitter-sweet }\end{array}$ & $\begin{array}{l}\text { celástrus } \\
\text { scándens }\end{array}$ & $\begin{array}{l}\text { small bees and } \\
\text { tlies }\end{array}$ & $\begin{array}{l}\text { Stigmatic tlowers gener- } \\
\text { ally separate from stam- } \\
\text { inate ones }\end{array}$ \\
\hline \multicolumn{4}{|c|}{ Polygala Family (Polygalaceae) } \\
\hline $\begin{array}{l}\text { Common Field } \\
\text { or } \\
\text { Purple Milkwort }\end{array}$ & $\begin{array}{l}\text { Polygala } \\
\text { sanguinea }\end{array}$ & Bees & $\begin{array}{l}\text { Fruiting organs withm a } \\
\text { tube split on the back to } \\
\text { insure contact with bee }\end{array}$ \\
\hline $\begin{array}{l}\text { Racemed } \\
\text { Milkwort } \\
\end{array}$ & $\begin{array}{l}\text { Polýgala } \\
\text { polygama }\end{array}$ & Bees & \multirow{2}{*}{$\begin{array}{l}\text { Produces both showy and } \\
\text { cleistogamous butls } \\
\text { Stamens and pistils are } \\
\text { enclosed in keel, the two } \\
\text { surfaces, ho we e e r, } \\
\text { turned in opposite direc- } \\
\text { tions. Produces also } \\
\text { cleistogamous buds }\end{array}$} \\
\hline $\begin{array}{l}\text { Fringed } \\
\text { i'olygala }\end{array}$ & $\begin{array}{l}\text { Polýcrala } \\
\text { paucifoulia }\end{array}$ & Bumblebees & \\
\hline \multicolumn{4}{|c|}{$\begin{array}{l}\text { Pulse Family (Leguminosae) } \\
\text { Notw.-As a family the peas follow the plan of concealing both anthers and } \\
\text { stigmas within a keel. When these organs are released by the liressure of the } \\
\text { insect the stigma strikes the visitor first, thus receiving pollen from another } \\
\text { flower before its own is bestowed upon its benefactor. }\end{array}$} \\
\hline $\begin{array}{c}\text { WVild } \\
\text { Lupine }\end{array}$ & $\begin{array}{l}\text { Lupìnus } \\
\text { perémnis }\end{array}$ & $\mid \begin{array}{c}\text { Long-lipped pol- } \\
\text { len-collecting bees }\end{array}$ & \\
\hline liattle box & $\begin{array}{l}\text { Crotalària } \\
\text { sagittàlis }\end{array}$ & Bees & \\
\hline $\begin{array}{l}\text { White } \\
\text { Sweet Clover }\end{array}$ & $\begin{array}{l}\text { Melilotus } \\
\text { alba }\end{array}$ & $\begin{array}{l}\text { Short-tongued } \\
\text { bees }\end{array}$ & \\
\hline $\begin{array}{l}\text { Red } \\
\text { Clover }\end{array}$ & $\begin{array}{l}\text { Trifólimm } \\
\text { praténse }\end{array}$ & $\begin{array}{l}\text { Bumblebees, } \\
\text { butterflies } \\
\text { (hummingbirds) }\end{array}$ & \multirow{3}{*}{$\begin{array}{l}\text { Produces also cleistoga- } \\
\text { mons buds }\end{array}$} \\
\hline $\begin{array}{l}\text { Trailing } \\
\text { Bush Clover }\end{array}$ & $\begin{array}{l}\text { Lespedèza } \\
\text { procumbens }\end{array}$ & Bees & \\
\hline $\begin{array}{c}\text { Canarlian or } \\
\text { Showy Tick-trefoil }\end{array}$ & $\begin{array}{l}\text { Desmòtlimm } \\
\text { Canadénse }\end{array}$ & $\begin{array}{c}\text { Pollen-collecting } \\
\text { bees (humblebees, } \\
\text { chiefly) }\end{array}$ & \\
\hline $\begin{array}{l}\text { Gronnd-nut, or } \\
\text { Wild Bean }\end{array}$ & $\begin{array}{l}\text { Ápios } \\
\text { tuberòsa }\end{array}$ & $\begin{array}{l}\text { Butterflies and } \\
\text { long-tongued bees }\end{array}$ & \multirow{2}{*}{$\begin{array}{l}\text { Pulp betweenanthers and } \\
\text { stigma. Produces also } \\
\text { cleistogamous buds } \\
\text { Produces also cleistoga- } \\
\text { mons buts }\end{array}$} \\
\hline Hog-Peanut & $\begin{array}{c}\text { Amplicarpea } \\
\text { monoica }\end{array}$ & Bees & \\
\hline $\begin{array}{l}\text { Butterfly } \\
\text { Pea }\end{array}$ & $\begin{array}{l}\text { Clitòria } \\
\text { Mariàna }\end{array}$ & bees & \multirow[b]{2}{*}{ Self-pollination probable } \\
\hline $\begin{array}{l}\text { Beach } \\
\text { Pea }\end{array}$ & $\begin{array}{l}\text { Láthyrus } \\
\text { marítimus }\end{array}$ & $\begin{array}{l}\text { Lolig-tongued } \\
\text { bees }\end{array}$ & \\
\hline
\end{tabular}




\begin{tabular}{|c|c|c|c|}
\hline \multicolumn{4}{|c|}{ Supplement } \\
\hline \multicolumn{4}{|c|}{ Pulse Family-Continued } \\
\hline COMMON NAME & $\begin{array}{l}\text { SEIFXTIFI } \\
\text { NAME }\end{array}$ & $\begin{array}{l}\text { INSECT } \\
\text { VISITURS }\end{array}$ & $\begin{array}{l}\text { METHOD OF PREYENT- } \\
\text { ING OR LIMITING SELF- } \\
\text { FERTILIZATION, ETE" }\end{array}$ \\
\hline $\begin{array}{l}\text { Bilue, Tufted or } \\
\text { cow Vetels }\end{array}$ & $\begin{array}{l}\text { Trícia } \\
\text { Crácea }\end{array}$ & $\begin{array}{l}\text { Flies, butterflies, } \\
\text { bees }\end{array}$ & Self-fertilization usual \\
\hline $\begin{array}{l}\text { Wild False } \\
\text { ludigo }\end{array}$ & $\begin{array}{l}\text { Baptisia } \\
\text { tinctoria }\end{array}$ & Bees & \\
\hline $\begin{array}{l}\text { Wild } \\
\text { Semina }\end{array}$ & $\begin{array}{l}\text { Cásiata } \\
\text { Mariantndiea }\end{array}$ & Bumblebees & \\
\hline $\begin{array}{l}\text { Small Flowering } \\
\text { Semma }\end{array}$ & $\begin{array}{l}\text { ('issia } \\
\text { núctitans }\end{array}$ & $\begin{array}{c}\text { Pollen-gatluering } \\
\text { bumblebees }\end{array}$ & $\begin{array}{l}\text { Anthers radiate away } \\
\text { from stigma }\end{array}$ \\
\hline \multicolumn{4}{|c|}{ Rose Family (Rosaceae) } \\
\hline \multicolumn{4}{|c|}{$\begin{array}{l}\text { Note, Roses as a family are apt to mature their anthers and stigmas simul- } \\
\text { tancousiy, but the former are usually turned outward, so that the insect visitor } \\
\text { maly strike the stigma first. }\end{array}$} \\
\hline Meadow-sweet & $\begin{array}{l}\text { Spirièal } \\
\text { sallicifólial }\end{array}$ & $\begin{array}{l}\text { Small bees (Andre- } \\
\text { nidle and Syrphi- } \\
\text { die) and beetles }\end{array}$ & $\begin{array}{l}\text { Stigma generally matures } \\
\text { before antlyers, thougl } \\
\text { self-fertilization is not } \\
\text { infrequent }\end{array}$ \\
\hline Nine-batrk & $\begin{array}{l}\text { Spirata } \\
\text { opmlifólia }\end{array}$ & $\begin{array}{c}\text { Bees } \\
\text { and flies } \\
\end{array}$ & \\
\hline $\begin{array}{l}\text { Ifard hack, or } \\
\text { steeplebush }\end{array}$ & $\begin{array}{l}\text { Spirièa } \\
\text { tomentosa }\end{array}$ & $\begin{array}{c}\text { Pollen-collecting } \\
\text { bees }\end{array}$ & $\begin{array}{l}\text { Self-fertilization very } \\
\text { common }\end{array}$ \\
\hline Goats-beard & $\begin{array}{l}\text { Spirièa } \\
\text { Arúncus }\end{array}$ & $\begin{array}{l}\text { Bees, flies, } \\
\text { and beetles }\end{array}$ & $\begin{array}{l}\text { Some flowers perfect, oth- } \\
\text { ers staminate, and oth- } \\
\text { ers stigmatic }\end{array}$ \\
\hline $\begin{array}{c}\text { Queen-of-the } \\
\text { I'rairie } \\
\end{array}$ & $\begin{array}{l}\text { Spiriàal } \\
\text { lobata }\end{array}$ & $\begin{array}{l}\text { Butterflies } \\
\text { and bees }\end{array}$ & \\
\hline $\begin{array}{l}\text { Indian Physic, or } \\
\text { Anerican Ipecac }\end{array}$ & $\begin{array}{l}\text { Gillènia } \\
\text { trifoliàta }\end{array}$ & $\begin{array}{l}\text { Small long- } \\
\text { tongned hees }\end{array}$ & \\
\hline $\begin{array}{c}\text { P'urple or water } \\
\text { Avens }\end{array}$ & $\begin{array}{l}\text { Geum } \\
\text { rivale }\end{array}$ & Bumblebees & $\begin{array}{l}\text { Stigmas generally mature } \\
\text { before anthers }\end{array}$ \\
\hline White Avens & $\begin{array}{l}\text { Gèmu } \\
\text { álbum }\end{array}$ & bees and flies & $\begin{array}{l}\text { Stigmas mature before } \\
\text { anthers }\end{array}$ \\
\hline $\begin{array}{l}\text { Virgina } \\
\text { Strawberry }\end{array}$ & $\begin{array}{c}\text { Fragària } \\
\text { Virginiàna }\end{array}$ & Several insects & $\begin{array}{l}\text { stigmatic flowers fre- } \\
\text { quently separate from } \\
\text { staminate flowers }\end{array}$ \\
\hline $\begin{array}{l}\text { Creeping } \\
\text { Dalibardia }\end{array}$ & $\begin{array}{l}\text { Dalibáliclal } \\
\text { rèpenss }\end{array}$ & & $\begin{array}{l}\text { Produces both sliowy aind } \\
\text { cleistogatmous buds }\end{array}$ \\
\hline $\begin{array}{l}\text { Porple flowering, } \\
\text { or Virginia } \\
\text { Raspberry }\end{array}$ & $\begin{array}{l}\text { liubus } \\
\text { ocloràtus }\end{array}$ & $\begin{array}{l}\text { Several inserts, } \\
\frac{\text { no special visitor }}{\text { lamblebees }}\end{array}$ & $\begin{array}{l}\text { Outer anthers mature a } \\
\text { little before stigmas, but } \\
\text { self-fertilization from } \\
\text { the inner row of anthers } \\
\text { is common }\end{array}$ \\
\hline $\begin{array}{l}\text { Wild lied } \\
\text { Raspberry }\end{array}$ & $\begin{array}{l}\text { Rùbus } \\
\text { strigusiss }\end{array}$ & $\begin{array}{l}\text { Pollen-collecting } \\
\text { beess }\end{array}$ & $\begin{array}{l}\text { Self-fertilization very } \\
\text { common }\end{array}$ \\
\hline $\begin{array}{c}\text { High } \\
\text { Blackberry }\end{array}$ & $\begin{array}{l}\text { linbus } \\
\text { villósus }\end{array}$ & Bumblebees & $\begin{array}{l}\text { Stigma generilly matures } \\
\text { a little before anthers. } \\
\text { Stamens turn away from } \\
\text { stigma. Self-fertiliza- } \\
\text { tion not uncommon. }\end{array}$ \\
\hline
\end{tabular}


Supplement

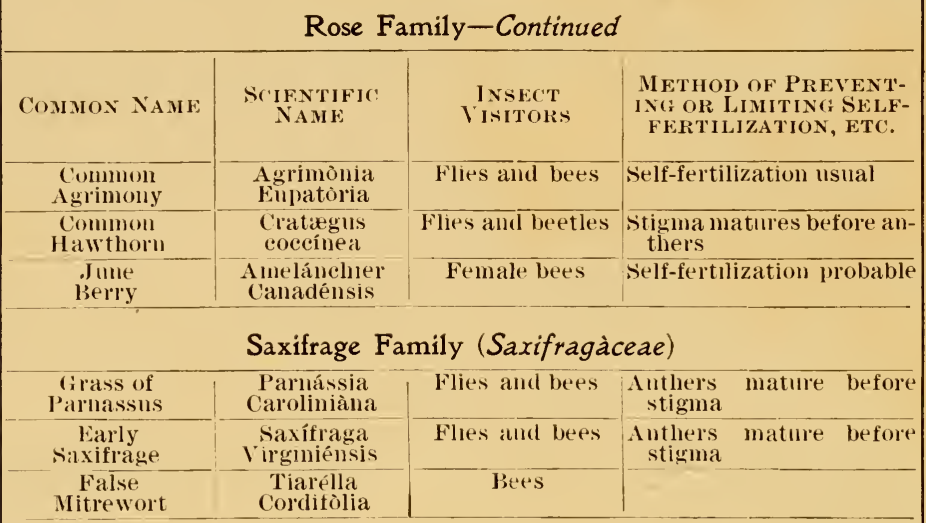

\section{Orpine Family (Crassulàceae)}

\begin{tabular}{|c|c|c|c|}
\hline $\begin{array}{l}\text { (Trpine, or } \\
\text { Live-forever }\end{array}$ & $\begin{array}{c}\text { Sédum } \\
\text { Téléphium }\end{array}$ & Bees and tlies & $\begin{array}{c}\text { Anthers mature before } \\
\text { stigma }\end{array}$ \\
\hline \multicolumn{4}{|c|}{ Witch-Hazel Family (Hamamelaceae) } \\
\hline Witel-Hazel & $\begin{array}{l}\text { Hamamèlıs } \\
\text { Virgimlea }\end{array}$ & Bees and flies & $\begin{array}{l}\text { Stigmatic flowers gener- } \\
\text { ally separate from stan- } \\
\text { inate flowers }\end{array}$ \\
\hline \multicolumn{4}{|c|}{ Evening-Primrose Family (Onagràceae) } \\
\hline $\begin{array}{l}\text { Enchanter's } \\
\text { Nightshade }\end{array}$ & $\begin{array}{l}\text { Circaea } \\
\text { Lutetiàna }\end{array}$ & Bees and flies & $\begin{array}{l}\text { Stigma a landing place for } \\
\text { incoming insects. Self- } \\
\text { fertilization infrequent }\end{array}$ \\
\hline $\begin{array}{l}\text { Great Willow-herb } \\
\text { or Fireweed }\end{array}$ & $\begin{array}{l}\text { Epilobium } \\
\text { angustifôlium }\end{array}$ & Bumblebees & $\begin{array}{l}\text { Anthers mature before } \\
\text { stigma }\end{array}$ \\
\hline Evening Primrose & $\begin{array}{l}\text { Enothèra } \\
\text { biénnis }\end{array}$ & $\begin{array}{c}\text { Motlis } \\
\text { (bumblebees, } \\
\text { humming birds) }\end{array}$ & $\begin{array}{l}\text { Anthers mature before } \\
\text { stigma }\end{array}$ \\
\hline $\begin{array}{l}\text { Common } \\
\text { Sundrop }\end{array}$ & $\begin{array}{l}\text { Enothèro } \\
\text { fructicòsa }\end{array}$ & $\begin{array}{l}\text { Bumblebees and } \\
\text { butterflies }\end{array}$ & $\begin{array}{l}\text { Stigmas protrude far be- } \\
\text { yond anthers. Self-fer- } \\
\text { tilization impossible } \\
\end{array}$ \\
\hline \multicolumn{4}{|c|}{ Melàstoma Family (Melastomàceae) } \\
\hline $\begin{array}{l}\text { Meadow-Beanty, } \\
\text { or Deer-(irass }\end{array}$ & $\begin{array}{l}\text { Rhéxia } \\
\text { Virgíniea }\end{array}$ & Bees & \\
\hline \multicolumn{4}{|c|}{ Loosestrife Family (Lythràceae) } \\
\hline Spiked Loosestrife & $\begin{array}{l}\text { Lýthrmun } \\
\text { Salicària }\end{array}$ & $\begin{array}{l}\text { Butterflies and } \\
\text { bees (flies) }\end{array}$ & Trimorphic \\
\hline \multicolumn{4}{|c|}{ Cactus Family (Cactàceae) } \\
\hline $\begin{array}{c}\text { Common } \\
\text { Prickly-Pear }\end{array}$ & $\begin{array}{l}\text { Opúntia } \\
\text { vulgàris } \\
\end{array}$ & $\begin{array}{c}\begin{array}{c}\text { Flies, bees, } \\
\text { beetles }\end{array} \\
\end{array}$ & Self-fertilization usual \\
\hline
\end{tabular}


Gourd Family (Cucurbitàceae)

\begin{tabular}{|c|c|c|c|}
\hline Comaron Name & $\begin{array}{l}\text { SiC IENTIFIC: } \\
\text { N.IME }\end{array}$ & $\begin{array}{l}\text { IXIECT } \\
\text { ISITORS }\end{array}$ & $\begin{array}{l}\text { METIIOI, OF PREVENT- } \\
\text { INAOR LIMITINE SELF- } \\
\text { FERTILIZATION, ETE' }\end{array}$ \\
\hline Star-Cur.umber & $\begin{array}{l}\text { ficyos } \\
\text { angulatus }\end{array}$ & $\begin{array}{l}\text { Several insects, } \\
\text { no special visilor }\end{array}$ & $\begin{array}{l}\text { Stigmatic flowers sepa- } \\
\text { late from staminate } \\
\text { flowers }\end{array}$ \\
\hline
\end{tabular}

\section{Parsley Family (Umbelliferae)}

\begin{tabular}{|c|c|c|c|}
\hline Blatek Sulake-root. & Sanicula & Sicveral inseets, & Stigmas mature before \\
\hline & Marylándica & no special visitor & $\begin{array}{l}\text { anthers, which are im- } \\
\text { prisoned benteath the } \\
\text { petals mithl all clanger of } \\
\text { self-fertilization is past. } \\
\text { Some flowers perfect, } \\
\text { others staminate only }\end{array}$ \\
\hline Common Carrot & Datueus ('arota & $\begin{array}{l}\text { Bees, wasps, flies, } \\
\text { beetles, etc. }\end{array}$ & $\begin{array}{l}\text { Stigmatic flowers on outer } \\
\text { edge. Staninate flow- } \\
\text { ers grouped in center }\end{array}$ \\
\hline sileet vicely & $\begin{array}{l}\text { Osmorrhiza } \\
\text { longistylis }\end{array}$ & Flies and bees & $\begin{array}{l}\text { Some flowers perfect, } \\
\text { others staminate. In } \\
\text { the perfect flowers the } \\
\text { anthers mature before } \\
\text { the stigmas }\end{array}$ \\
\hline $\begin{array}{l}\text { Water Hemlock, } \\
\text { or } \\
\text { Spotted Cowbane }\end{array}$ & Cicuta maculata & $\begin{array}{c}\text { Flies, bees, and } \\
\text { wasps }\end{array}$ & $\begin{array}{l}\text { Some perfect, others stam- } \\
\text { inate flowers. Perfect } \\
\text { flowers mature anthers } \\
\text { before stigmas }\end{array}$ \\
\hline (ow-Parsuip) & $\begin{array}{l}\text { Heraclèmm } \\
\text { lanàtım }\end{array}$ & $\begin{array}{l}\text { Flies, bees, aud } \\
\text { wasps }\end{array}$ & $\begin{array}{l}\text { Anthers mature before } \\
\text { stigmas }\end{array}$ \\
\hline
\end{tabular}

\section{Ginseng Family (Araliàceae)}

\begin{tabular}{|c|c|c|c|}
\hline Spikenard & Aràlia racenosa & $\begin{array}{c}\text { Chiefly flies and } \\
\text { bees }\end{array}$ & $\begin{array}{l}\text { Some flowers perfect, } \\
\text { others staminate, others } \\
\text { stigmatic }\end{array}$ \\
\hline $\begin{array}{l}\text { Common Wild } \\
\text { Sarsaparilla }\end{array}$ & $\begin{array}{l}\text { Aralia } \\
\text { mudicaùlis }\end{array}$ & Flies and bees & \\
\hline linselng & $\begin{array}{l}\text { Aralia } \\
\text { quinquefolia }\end{array}$ & $\begin{array}{l}\text { Several insects, } \\
\text { no special visitor }\end{array}$ & $\begin{array}{l}\text { Bears both slowy and } \\
\text { eleistogamous flowers }\end{array}$ \\
\hline
\end{tabular}

\section{Dogwood Family (Cornàceae)}

\begin{tabular}{|c|c|c|c|}
\hline $\begin{array}{l}\text { Flowering } \\
\text { bogwood }\end{array}$ & $\begin{array}{l}\text { Cómus } \\
\text { flóricla }\end{array}$ & $\begin{array}{l}\text { Bees, tlies, and } \\
\text { butterflies }\end{array}$ & Self-fertilization jossilse \\
\hline \multicolumn{4}{|c|}{ Honeysuckle Family (Caprifoliàceae) } \\
\hline Twin-flower & $\begin{array}{l}\text { Limnà̀a } \\
\text { boreălis }\end{array}$ & liees and flies & $\begin{array}{l}\text { stigma protrudes, } 11 \text { ad- } \\
\text { vance of anthers }\end{array}$ \\
\hline $\begin{array}{c}\text { Coral or Trumpet } \\
\text { Honeysuckle }\end{array}$ & $\begin{array}{c}\text { Lonicera } \\
\text { sempérvirens }\end{array}$ & II mmung birch & \\
\hline $\begin{array}{l}\text { Sweet Wilk } \\
\text { Honeysuckle }\end{array}$ & $\begin{array}{l}\text { Lonicera } \\
\text { gràta }\end{array}$ & splinx moth & $\begin{array}{l}\text { Stigma protrules and re- } \\
\text { ceives incoming bee }\end{array}$ \\
\hline $\begin{array}{c}\text { Bush } \\
\text { Honeysuckle }\end{array}$ & $\begin{array}{l}\text { Diervílla } \\
\text { trífida }\end{array}$ & Bees & $\begin{array}{l}\text { Stigma protrudles and re- } \\
\text { ceives incoming bee }\end{array}$ \\
\hline
\end{tabular}




\begin{tabular}{|c|c|c|c|}
\hline \multicolumn{4}{|c|}{ Supplement } \\
\hline \multicolumn{4}{|c|}{ Honeysuckle Family-Continued } \\
\hline COMMON NAME & $\begin{array}{l}\text { SCIENTIFIC } \\
\text { NAME }\end{array}$ & $\begin{array}{l}\text { INSECT } \\
\text { VISITORS }\end{array}$ & $\begin{array}{l}\text { METHOD OF PREVENT- } \\
\text { INGOR LIMITING SELF- } \\
\text { FERTILIZATION, ETC. }\end{array}$ \\
\hline $\begin{array}{c}\text { High } \\
\text { Bush-Cranberry }\end{array}$ & $\begin{array}{l}\text { Vibúruum } \\
\text { Ópulus }\end{array}$ & $\begin{array}{l}\text { Small bees and } \\
\text { flies }\end{array}$ & $\begin{array}{l}\text { I nsects cross-fertilize } \\
\text { flowers merely by crawl- } \\
\text { ing over the elusters }\end{array}$ \\
\hline Hobblebush & $\begin{array}{l}\text { Viburuum } \\
\text { lantanoides }\end{array}$ & $\begin{array}{l}\text { Small bees } \\
\text { (Andrena) } \\
\text { and flies }\end{array}$ & $\begin{array}{l}\text { I nsects eross-fertilize } \\
\text { flowers merely by } \\
\text { erawling over the clus- } \\
\text { ters }\end{array}$ \\
\hline Common Elder & $\begin{array}{l}\text { Sambùcus } \\
\text { Canadénsis }\end{array}$ & $\begin{array}{l}\text { Pollen gatherers, } \\
\text { flies, beetles, and } \\
\text { lesser bees }\end{array}$ & $\begin{array}{l}\text { Stamens radiate away } \\
\text { from stigma }\end{array}$ \\
\hline \multicolumn{4}{|c|}{ Madder Family (Rubiàceae) } \\
\hline Partridge-berry & $\begin{array}{c}\text { Mitchélla } \\
\text { répens }\end{array}$ & Bees & Dimorphic blossoms \\
\hline Button-bush & $\begin{array}{l}\text { Cephalanthus } \\
\text { occidentalis }\end{array}$ & $\begin{array}{l}\text { Bees and butter- } \\
\text { flies chiefly }\end{array}$ & $\begin{array}{l}\text { Anthers mature before } \\
\text { stigma. Peculiar meth- } \\
\text { od. The pollen is shed } \\
\text { on the style before the } \\
\text { buds open, but is car- } \\
\text { ried away by insects be- } \\
\text { fore the stigma natures }\end{array}$ \\
\hline Bluets & $\begin{array}{l}\text { Houstònia } \\
\text { catrùlea }\end{array}$ & $\begin{array}{c}\text { Flies, bees, and } \\
\text { butterflies }\end{array}$ & Dmorphic flowers \\
\hline \multicolumn{4}{|c|}{ Teazel Family (Dipsàceae) } \\
\hline Wild Teazel & $\begin{array}{l}\text { Dípsacus } \\
\text { sylvéstris }\end{array}$ & Bumblebees & $\begin{array}{l}\text { Anthers mature before } \\
\text { the stigma }\end{array}$ \\
\hline \multicolumn{4}{|c|}{$\begin{array}{l}\text { Composite Family (Compositae) } \\
\text { mposita have developed two eharacteristics which insure } \\
\text { he first is the method of grouping many small florets in one } \\
\text { the attention of insects by a great expanse of color the the } \\
\text { described in the text under the eone-flower of ejecting their } \\
\text { es with the stigmas, which act as piston rods. After the pol- } \\
\text { ed the stigmas mature and are ready to receive foreign pollen. }\end{array}$} \\
\hline $\begin{array}{l}\text { Common } \\
\text { Burdock }\end{array}$ & $\begin{array}{l}\text { Lápla } \\
\text { officinàlis }\end{array}$ & $\begin{array}{c}\text { Butterflies and } \\
\text { bumblebees }\end{array}$ & \\
\hline $\begin{array}{c}\text { Common } \\
\text { Tansy }\end{array}$ & $\begin{array}{l}\text { Janacètum } \\
\text { vulgàre }\end{array}$ & $\begin{array}{l}\text { Bees, flies, beetles, } \\
\text { and butterflies }\end{array}$ & \\
\hline $\begin{array}{l}\text { Pearly Everlast- } \\
\text { ing, or } \\
\text { Immortelle }\end{array}$ & $\begin{array}{l}\text { Autennària } \\
\text { margaritàcea }\end{array}$ & Flies and beetles & $\begin{array}{l}\text { Stigmatic flowers gentr- } \\
\text { ally selparate from stam- } \\
\text { inate flowers }\end{array}$ \\
\hline Iron-weed & $\begin{array}{c}\text { Veruònia } \\
\text { Noveboracénsis }\end{array}$ & $\begin{array}{l}\text { Butterflies and } \\
\text { long-lipped bees }\end{array}$ & \\
\hline $\begin{array}{c}\text { Common } \\
\text { Blaziug-star }\end{array}$ & $\begin{array}{c}\text { Jiàtris } \\
\text { squarròsa }\end{array}$ & $\begin{array}{l}\text { Long-tongued } \\
\text { bees and flies }\end{array}$ & \\
\hline $\begin{array}{l}\text { Purple Thorough- } \\
\text { wort, or Joe-Pye } \\
\text { weed }\end{array}$ & $\begin{array}{l}\text { Eupatòrium } \\
\text { purpuxeum }\end{array}$ & $\begin{array}{l}\text { Butterflies chiefly } \\
\text { (bees and flies) }\end{array}$ & $\begin{array}{l}\text { Anthers mature before } \\
\text { stigma }\end{array}$ \\
\hline $\begin{array}{c}\text { Thoroughwort, } \\
\text { or Boneset }\end{array}$ & $\begin{array}{l}\text { Eupatòrium } \\
\text { perfoliàtum }\end{array}$ & $\begin{array}{c}\text { Beetles, flies, } \\
\text { wasps, and bees }\end{array}$ & \\
\hline
\end{tabular}




\begin{tabular}{|c|c|c|c|}
\hline \multicolumn{4}{|c|}{ Supplement } \\
\hline \multicolumn{4}{|c|}{ Composite Family - Continued } \\
\hline Common Name & $\begin{array}{l}\text { SCIFNTIFIC } \\
\text { NAIE }\end{array}$ & $\begin{array}{l}\text { INSECT } \\
\text { VISITOR }\end{array}$ & $\begin{array}{l}\text { METHOH OF PREVENT- } \\
\text { ING OR LIMITING SELF- } \\
\text { FERTILIZATION, ETC. }\end{array}$ \\
\hline $\begin{array}{l}\text { Gromudsel-bush } \\
\text { or tree }\end{array}$ & $\begin{array}{l}\text { Senècio } \\
\text { vulgaris }\end{array}$ & $\begin{array}{c}\text { Very few insects, } \\
\text { bees ehiefly }\end{array}$ & $\begin{array}{l}\text { Stigniatic flowers fre- } \\
\text { quently separate from } \\
\text { staminate ones, self- } \\
\text { fertilization msual, how- } \\
\text { ever, smee many seeds } \\
\text { are produced even in } \\
\text { seasons mufavorable to } \\
\text { insect visits } \\
\end{array}$ \\
\hline $\begin{array}{l}\text { Goldeu Ragwort, } \\
\text { or Squaw-weed }\end{array}$ & $\begin{array}{l}\text { Senècio } \\
\text { aùrens }\end{array}$ & Many insects & \\
\hline $\begin{array}{l}\text { Elacampane, or } \\
\text { Horseheal }\end{array}$ & Ímia & $\cdot \cdot$ & $\begin{array}{l}\text { Disk florets contain both } \\
\text { pistils and stamens, ray } \\
\text { florets apt to be stamin- } \\
\text { ate only }\end{array}$ \\
\hline folden-Rods & Solidliàgo & & $\begin{array}{l}\text { Disk florets contain both } \\
\text { pistils and stamens, ray } \\
\text { florets apt to be stami- } \\
\text { nate only }\end{array}$ \\
\hline $\begin{array}{l}\text { Starworts, } \\
\text { or Asters }\end{array}$ & Áster & " & Self-fertilization frequent \\
\hline $\begin{array}{c}\text { Daisy-leaved } \\
\text { Fleabane, or } \\
\text { Robin's Plantain }\end{array}$ & $\begin{array}{c}\text { Erígeron } \\
\text { bellidifòlıum }\end{array}$ & $\begin{array}{c}\text { Bees and } \\
\text { thistle butterfly }\end{array}$ & \\
\hline $\begin{array}{c}\text { Larger } \\
\text { Daisy-Fleabane }\end{array}$ & $\begin{array}{l}\text { Erigeron } \\
\text { ânnแแmm }\end{array}$ & Many insects & Self-fertilization usual \\
\hline $\begin{array}{c}\text { Yarrow, } \\
\text { or Milfoil } \\
\end{array}$ & $\begin{array}{l}\text { Achillèa } \\
\text { Millefolium }\end{array}$ & $\begin{array}{l}\text { Bees, flies, butter- } \\
\text { flies, and beetles }\end{array}$ & \\
\hline $\begin{array}{c}\text { Common May } \\
\text { weed, or Camomile }\end{array}$ & $\begin{array}{l}\text { Marùta } \\
\text { Cótula } \\
\end{array}$ & Flies & liay flowers neutral \\
\hline $\begin{array}{c}\text { Common } \\
\text { Daisy }\end{array}$ & $\begin{array}{l}\text { Chrysinthemmm } \\
\text { Lencinthemmm }\end{array}$ & Numerous insects & $\begin{array}{l}\text { Self-fertilization frequent } \\
\text { in absence of insects }\end{array}$ \\
\hline Sncezeweed & $\begin{array}{l}\text { Helènium } \\
\text { autumnàle }\end{array}$ & $\begin{array}{c}\text { Flies, butterflies, } \\
\text { and bees }\end{array}$ & $\begin{array}{l}\text { Disk florets contain both } \\
\text { pistils and stamens, } \\
\text { many florets apt to be } \\
\text { stigmatic only }\end{array}$ \\
\hline $\begin{array}{c}\text { Lance-leaved } \\
\text { tick-seed, } \\
\text { Golden Coreopsis. }\end{array}$ & $\begin{array}{l}\text { Coreópsis } \\
\text { lanceolata }\end{array}$ & $\begin{array}{l}\text { Flies and } \\
\text { butterflies }\end{array}$ & $\begin{array}{l}\text { Disk flowers perfect, ray- } \\
\text { flowers without anther's } \\
\text { or stigmas }\end{array}$ \\
\hline $\begin{array}{c}\text { Larger } \\
\text { Bur-Marigold } \\
\end{array}$ & $\begin{array}{l}\text { Bìdens chrysan- } \\
\text { themoìles }\end{array}$ & Many insects & $\begin{array}{l}\text { Disk flowers perfect, self- } \\
\text { fertilization usual }\end{array}$ \\
\hline $\begin{array}{l}\text { Tall or Giant } \\
\text { Sunflower }\end{array}$ & $\begin{array}{c}\text { Heliánthus } \\
\text { gigantèus }\end{array}$ & $*$ & $\begin{array}{l}\text { Disk flowers perfect, self- } \\
\text { fertilization usual }\end{array}$ \\
\hline $\begin{array}{l}\text { False Sunflower, } \\
\text { or Ox-eye }\end{array}$ & $\begin{array}{l}\text { Heliónsis } \\
\text { laèvis }\end{array}$ & $\because$ & $\begin{array}{l}\text { Disk flowers perfect, self- } \\
\text { fertilization usual }\end{array}$ \\
\hline $\begin{array}{c}\text { Black-eyed Susan, } \\
\text { or Cone-Flower }\end{array}$ & $\begin{array}{c}\text { Rudbéckia } \\
\text { hírta }\end{array}$ & $\cdot \cdot$ & $\begin{array}{l}\text { Disk flowers perfect, self- } \\
\text { fertilization usual }\end{array}$ \\
\hline $\begin{array}{c}\text { Orange or Tawily } \\
\text { Hawkweed }\end{array}$ & $\begin{array}{l}\text { Ilieràcium } \\
\text { paniculatum }\end{array}$ & $\begin{array}{l}\text { Flies and } \\
\text { smaller bees }\end{array}$ & \\
\hline $\begin{array}{c}\text { Common } \\
\text { Dandelion }\end{array}$ & $\begin{array}{l}\text { Taráxacmu } \\
\text { Dells-leòms }\end{array}$ & Many insects & $\begin{array}{l}\text { Flowers of early spring } \\
\text { and of late fall not vis- } \\
\text { ited by insects, but are } \\
\text { fertile, self-fertilization } \\
\text { common }\end{array}$ \\
\hline
\end{tabular}




\section{Supplement}

\begin{tabular}{|c|c|c|c|}
\hline \multicolumn{4}{|c|}{ Composite Family-Continued } \\
\hline CominoN NAME & $\begin{array}{l}\text { SCIENTIFIC } \\
\text { NAME }\end{array}$ & $\begin{array}{l}\text { INSECT } \\
\text { VISITORS }\end{array}$ & $\begin{array}{l}\text { METHOD OF PREVENT- } \\
\text { ING OR LINITING SELF- } \\
\text { FERTILIZATION, ETC. }\end{array}$ \\
\hline Sow Thistle & $\begin{array}{l}\text { Sónchus } \\
\text { Alvénsis }\end{array}$ & Many insects & Self-fertilization common \\
\hline \multicolumn{4}{|c|}{ Lobelia Family (Lobeliàceae) } \\
\hline $\begin{array}{l}\text { Great Blue } \\
\text { Lobelia }\end{array}$ & $\begin{array}{l}\text { Lobèlia } \\
\text { syphilítica }\end{array}$ & Bumblebees & $\begin{array}{l}\text { Anthers mature before } \\
\text { stlgmas. Stigmas pro- } \\
\text { tunde far beyond anthers }\end{array}$ \\
\hline \multicolumn{4}{|c|}{ Campanula Family (Campanulàceae) } \\
\hline $\begin{array}{c}\text { Venus's } \\
\text { Looking-glass }\end{array}$ & $\begin{array}{l}\text { Speculària } \\
\text { perfoliàta }\end{array}$ & Many insects & $\begin{array}{l}\text { Produces both showy and } \\
\text { cleistogamous flowers } \\
\text { Anthers matme before } \\
\text { stignas }\end{array}$ \\
\hline $\begin{array}{l}\text { Common } \\
\text { Harebell }\end{array}$ & $\begin{array}{l}\text { Campánula } \\
\text { rotundifòlia }\end{array}$ & $\begin{array}{c}\text { Bees and butter- } \\
\text { flies (flies and } \\
\text { beetles) }\end{array}$ & $\begin{array}{l}\text { Anthers mature before } \\
\text { stigma }\end{array}$ \\
\hline \multicolumn{4}{|c|}{ Heath Family (Ericàceae) } \\
\hline $\begin{array}{c}\text { Trailing Arbutus, } \\
\text { or } \\
\text { Gromed Laurel } \\
\end{array}$ & $\begin{array}{l}\text { Epigaèa } \\
\text { rèpens }\end{array}$ & $\begin{array}{c}\text { Femald bumble- } \\
\text { bees, } \\
\text { flies and bees }\end{array}$ & $\begin{array}{l}\text { In a transition state. } \\
\text { showng a tenclency } \\
\text { toward trimorphism }\end{array}$ \\
\hline $\begin{array}{l}\text { Common or Black } \\
\text { Huckleberry }\end{array}$ & $\begin{array}{c}\text { Gaylussácia } \\
\text { ressinòsa }\end{array}$ & Small bees & $\begin{array}{l}\text { stigma protrudes and } \\
\text { strikes neoming bee }\end{array}$ \\
\hline Andromeda & $\begin{array}{l}\text { Andrómeda } \\
\text { floribúnda }\end{array}$ & Small bees & $\begin{array}{l}\text { Stigma protrules beyond } \\
\text { anthers. See text }\end{array}$ \\
\hline Mountam Laurel & $\begin{array}{c}\text { Kálmia } \\
\text { latifòlia }\end{array}$ & Bees & 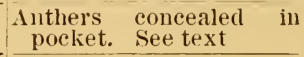 \\
\hline $\begin{array}{l}\text { American or Great } \\
\text { Rhododendron }\end{array}$ & $\begin{array}{c}\text { Rhododéndron } \\
\text { máximum }\end{array}$ & Bees & \\
\hline $\begin{array}{l}\text { Purple Azalea, or } \\
\text { Pinxter-flower } \\
\end{array}$ & $\begin{array}{c}\text { Azàlea } \\
\text { nurliflòra } \\
\end{array}$ & Female bees & $\begin{array}{l}\text { Stigma protrudes and } \\
\text { strikes incoming bee }\end{array}$ \\
\hline Wintergreen & $\begin{array}{l}\text { Pýrola } \\
\text { rotundifòlia }\end{array}$ & Bees and flies & $\begin{array}{l}\text { Stigma protrudes and } \\
\text { strikes incoming bee }\end{array}$ \\
\hline $\begin{array}{c}\text { Spotted } \\
\text { Pipsissewa }\end{array}$ & $\begin{array}{l}\text { Chimáphila } \\
\text { maculata }\end{array}$ & Bees and flies & $\begin{array}{l}\text { Stigma stands above an- } \\
\text { thers }\end{array}$ \\
\hline \multicolumn{4}{|c|}{ Holly Family (Aquifoliaceae) } \\
\hline Mountain Holly & $\begin{array}{c}\text { Nemopánthies } \\
\text { Canadénsis }\end{array}$ & $\begin{array}{c}\text { Several insects, } \\
\text { no special visitor }\end{array}$ & $\begin{array}{l}\text { Staminate flowers sepa- } \\
\text { rate from stigmatic ones }\end{array}$ \\
\hline Black Alder & Ilex verticillàta & $\begin{array}{c}\text { Several insects, } \\
\text { no special visitor }\end{array}$ & $\begin{array}{l}\text { Staminate flowers sepa- } \\
\text { rate from stigmatic ones }\end{array}$ \\
\hline \multicolumn{4}{|c|}{ Primrose Family (Primulàceae) } \\
\hline $\begin{array}{l}\text { Shooting Star, or } \\
\text { American Cowslip }\end{array}$ & $\begin{array}{l}\text { Dodecàthon } \\
\text { Meàdia }\end{array}$ & $\begin{array}{c}\text { Female } \\
\text { bumblebees }\end{array}$ & $\begin{array}{l}\text { Stigma protrudes and } \\
\text { strikes incoming bee }\end{array}$ \\
\hline $\begin{array}{c}\text { Star-flower, or } \\
\text { American Chick- } \\
\text { weed }\end{array}$ & $\begin{array}{l}\text { Trientàlis } \\
\text { Americâna }\end{array}$ & $\begin{array}{l}\text { Pollen-collecting } \\
\text { bees and flies }\end{array}$ & $\begin{array}{l}\text { Stigma matures before the } \\
\text { anthers }\end{array}$ \\
\hline
\end{tabular}




\begin{tabular}{|c|c|c|c|}
\hline \multicolumn{4}{|c|}{ Supplement } \\
\hline \multicolumn{4}{|c|}{ Primrose Family-Continued } \\
\hline Commox Name & $\begin{array}{l}\text { SCIENTIFIC } \\
\text { NAME }\end{array}$ & $\begin{array}{l}\text { INSECT } \\
\text { VISITORS }\end{array}$ & $\begin{array}{l}\text { METHOD OF PREVENT- } \\
\text { ING OR LIMTING SELF- } \\
\text { FERTILIZATION, ETC. }\end{array}$ \\
\hline $\begin{array}{l}\text { Lance-leaved } \\
\text { Loosestrife }\end{array}$ & $\begin{array}{l}\text { Lysimàehia } \\
\text { lanceolâta }\end{array}$ & $\begin{array}{l}\text { Female bees } \\
\text { (macropis) }\end{array}$ & $\begin{array}{l}\text { Stamens drawn away from } \\
\text { style by expanding pet- } \\
\text { als dluring time stigma is } \\
\text { receptive }\end{array}$ \\
\hline $\begin{array}{l}\text { Common } \\
\text { Pimpernel }\end{array}$ & $\begin{array}{l}\text { Anagállis } \\
\text { arvénsis }\end{array}$ & $\begin{array}{l}\text { Pollen-eollecting } \\
\text { insects }\end{array}$ & Self-fertilization frequent \\
\hline \multicolumn{4}{|c|}{ Bladderwort Family (Lentibulàceae) } \\
\hline $\begin{array}{c}\text { Large } \\
\text { Bladdlerwort }\end{array}$ & $\begin{array}{l}\text { Utrieulàia } \\
\text { vulgarıs }\end{array}$ & Bees and thies & $\begin{array}{l}\text { As soon as the incommun } \\
\text { inseet fertilizes the stig } \\
\text { ma, it rolls np to prevent } \\
\text { contaet with its own } \\
\text { pollen }\end{array}$ \\
\hline \multicolumn{4}{|c|}{ Bignonia Family (Bıgnoniàceae) } \\
\hline $\begin{array}{c}\text { Wild } \\
\text { Trumpet-flower }\end{array}$ & $\begin{array}{l}\text { Tẻcoma } \\
\text { radìcans }\end{array}$ & $\begin{array}{l}\text { II ummung bird } \\
\text { (Large noths) }\end{array}$ & $\begin{array}{l}\text { Lobes of stigma close } \\
\text { when touched }\end{array}$ \\
\hline \multicolumn{4}{|c|}{ Broom-Rape Family (Orobanchàceae) } \\
\hline $\begin{array}{l}\text { Beech-drops, or } \\
\text { Cancer-root }\end{array}$ & $\begin{array}{l}\text { Epiphègus } \\
\text { Virginiăna }\end{array}$ & $\begin{array}{c}\text { Several minects, } \\
\text { no special visitor }\end{array}$ & $\begin{array}{l}\text { P'roduces cleistogamous } \\
\text { buds. Perfect flowers } \\
\text { are sterile }\end{array}$ \\
\hline \multicolumn{4}{|c|}{ Figwort Family (Schrophulariàceae) } \\
\hline Common Mullein & $\begin{array}{l}\text { Verbáscum } \\
\text { Thápsus }\end{array}$ & $\begin{array}{c}\text { Pollen-collecting } \\
\text { bees and flies }\end{array}$ & $\begin{array}{l}\text { Stigma protrudes and } \\
\text { strikes incommi bee }\end{array}$ \\
\hline Culver's Root & $\begin{array}{l}\text { Verónica } \\
\text { Virgíniea }\end{array}$ & Many insects & $\begin{array}{l}\text { Anthers mature before } \\
\text { the stigmas }\end{array}$ \\
\hline $\begin{array}{c}\text { Broolilume, or } \\
\text { Water Speedwell }\end{array}$ & $\begin{array}{l}\text { Verónica } \\
\text { Americàna }\end{array}$ & " & $\begin{array}{l}\text { Anthers mature before } \\
\text { the stigmas }\end{array}$ \\
\hline $\begin{array}{l}\text { Common } \\
\text { Speedwell }\end{array}$ & $\begin{array}{l}\text { Verónica } \\
\text { ofticinallis }\end{array}$ & $"$. & $\begin{array}{l}\text { Growng indense clusters } \\
\text { eross-fertilization is ef } \\
\text { fected by inseets crawl } \\
\text { ing over the head }\end{array}$ \\
\hline $\begin{array}{l}\text { Blue-eyed Mary, } \\
\text { or Broad-leaved } \\
\text { Collmsia }\end{array}$ & $\begin{array}{c}\text { Collínsia } \\
\text { vérna }\end{array}$ & $\begin{array}{l}\text { Pollen-collecting } \\
\text { bees (Osmia) }\end{array}$ & $\begin{array}{l}\text { Two sets of stamens (long } \\
\text { and short) maturng at } \\
\text { different intervals }\end{array}$ \\
\hline $\begin{array}{l}\text { Blue or Wild } \\
\text { Toadflax }\end{array}$ & $\begin{array}{l}\text { Linària } \\
\text { Calladénsis }\end{array}$ & $\begin{array}{l}\text { Long-tongued bees } \\
\text { and butterflies }\end{array}$ & \\
\hline $\begin{array}{l}\text { Butter-and-Eggs, } \\
\text { or } \\
\text { Common Toadflax }\end{array}$ & $\begin{array}{l}\text { Linària } \\
\text { V'ulgàrıs }\end{array}$ & $\begin{array}{c}\text { Bumblebees and } \\
\text { butterflies }\end{array}$ & $\begin{array}{l}\text { Stamens of two length } \\
\text { Self-fertilization possi- } \\
\text { ble }\end{array}$ \\
\hline $\begin{array}{c}\text { Large Purple } \\
\text { Gerardia }\end{array}$ & $\begin{array}{l}\text { Gerádia } \\
\text { purpulrea }\end{array}$ & Bees & $\begin{array}{l}\text { Stigma protrudes beyoud } \\
\text { anthers }\end{array}$ \\
\hline $\begin{array}{l}\text { Downy False } \\
\text { Foxglove }\end{array}$ & $\begin{array}{l}\text { Geráslia } \\
\text { Hầva }\end{array}$ & Bumblebees & $\begin{array}{l}\text { Stigma protrudes beyond } \\
\text { anthers and strikes in- } \\
\text { eommg pollen-laden bee }\end{array}$ \\
\hline
\end{tabular}




\section{Supplencut}

\section{Figwort Family-Continued}

\begin{tabular}{|c|c|c|c|}
\hline COMMON NAME & $\begin{array}{l}\text { SCIENTIFIC } \\
\text { NAME }\end{array}$ & $\begin{array}{l}\text { INSECT } \\
\text { VISITORS }\end{array}$ & $\begin{array}{l}\text { METHOD OF PREVENT- } \\
\text { INGOR LIMITINGSELF- } \\
\text { FERTILIZATION, ETC. }\end{array}$ \\
\hline Monkey Flower & $\begin{array}{l}\text { Mímulus } \\
\text { ríngens }\end{array}$ & $\begin{array}{l}\text { Long-tongued } \\
\text { bees }\end{array}$ & $\begin{array}{l}\text { Two sets of stamens and } \\
\text { sensitive stigma which } \\
\text { rolls up after contact } \\
\text { with visitor, exposing } \\
\text { stamens which then } \\
\text { shed their pollen }\end{array}$ \\
\hline Figwort & $\begin{array}{l}\text { Serophulària } \\
\text { nodósa }\end{array}$ & Wasps & $\begin{array}{l}\text { Stigmas mature before } \\
\text { anthers. See text }\end{array}$ \\
\hline $\begin{array}{l}\text { Snake-head, } \\
\text { or Balmony }\end{array}$ & $\begin{array}{l}\text { Chelòne } \\
\text { glàbra }\end{array}$ & Bumblebees & $\begin{array}{l}\text { Anthers mature before } \\
\text { stigma }\end{array}$ \\
\hline $\begin{array}{l}\text { Hairy Beard } \\
\text { Tongue }\end{array}$ & $\begin{array}{l}\text { Pentstèmon } \\
\text { pubéscens }\end{array}$ & $\begin{array}{l}\text { Long-tongued } \\
\text { bees }\end{array}$ & $\begin{array}{l}\text { Anthers mature before } \\
\text { stigmas }\end{array}$ \\
\hline $\begin{array}{l}\text { Scarlet Painted } \\
\text { Cus }\end{array}$ & $\begin{array}{l}\text { Castilleia } \\
\text { coccínea }\end{array}$ & Humming bircls & \\
\hline Wood Betony & $\begin{array}{l}\text { Pedicularís } \\
\text { Canadénsis }\end{array}$ & Bees & See text \\
\hline
\end{tabular}

\section{Acanthus Family (Acanthàceae)}

\begin{tabular}{l|l|l|l} 
Hairy Ruélia & Ruéllia ciliòsa & Many insects & $\begin{array}{c}\text { Bears both showy and } \\
\text { cleistogamous flowers }\end{array}$
\end{tabular}

\section{Vervain Family (Verbenàceae)}

\begin{tabular}{|l|l|l|l|}
\hline Blue Vervain & $\begin{array}{l}\text { Verbèna } \\
\text { luastàta }\end{array}$ & $\begin{array}{c}\text { Bees and } \\
\text { butterflies }\end{array}$ \\
\hline
\end{tabular}

\section{Mint Family (Labiàtae)}

\begin{tabular}{|c|c|c|c|}
\hline spear Mint & Méntha víridis & Many insects & $\begin{array}{l}\text { Anthers mature before } \\
\text { stigmas }\end{array}$ \\
\hline Horsebalm & $\begin{array}{l}\text { Collinsonnia } \\
\text { Cantaténsis }\end{array}$ & Bumblebees & $\begin{array}{l}\text { Stigma matures before } \\
\text { anthers }\end{array}$ \\
\hline Creeping Thyme & $\begin{array}{l}\text { Thýmus } \\
\text { Selpýllum }\end{array}$ & $\begin{array}{l}\text { Bumblebees, flies, } \\
\text { and butterflies }\end{array}$ & $\begin{array}{l}\text { Some flowers perfect, oth- } \\
\text { ers stigmatic, others } \\
\text { staminate }\end{array}$ \\
\hline $\begin{array}{l}\text { Oswego Tea, } \\
\text { or Bee-Balm }\end{array}$ & $\begin{array}{c}\text { Monárda } \\
\text { dídyma }\end{array}$ & $"$ & \\
\hline Wild Bergamot & $\begin{array}{l}\text { Monárda } \\
\text { fistulòsa, }\end{array}$ & $" 6$ & $\begin{array}{l}\text { Anthers mature iefore } \\
\text { stigmas }\end{array}$ \\
\hline Gromnd Ivy & $\begin{array}{l}\text { Népeta } \\
\text { Glechòma }\end{array}$ & Many insects & $\begin{array}{l}\text { Anthers and stigmas ma- } \\
\text { ture at different periods } \\
\text { in larger flowers, small } \\
\text { flowers stigmatic only }\end{array}$ \\
\hline $\begin{array}{c}\text { False } \\
\text { Dragon-Head }\end{array}$ & $\begin{array}{l}\text { Physostègia } \\
\text { Virginiàila }\end{array}$ & Bumblebees & $\begin{array}{l}\text { Authers mature before } \\
\text { stigma }\end{array}$ \\
\hline $\begin{array}{l}\text { Self-Heal, } \\
\text { or Iieal-all }\end{array}$ & $\begin{array}{l}\text { Brunélla } \\
\text { vulgàris }\end{array}$ & Bumblebees & $\begin{array}{c}\text { Anthers mature before } \\
\text { stigna }\end{array}$ \\
\hline Skullcap & $\begin{array}{l}\text { Scutlellària } \\
\text { lateriflòra }\end{array}$ & Bees & $\begin{array}{l}\text { Anthers mature before } \\
\text { stigma }\end{array}$ \\
\hline $\begin{array}{l}\text { Common } \\
\text { Motherwort }\end{array}$ & $\begin{array}{l}\text { Leomirus } \\
\text { Cardiaca }\end{array}$ & Bumblebees & Two lengths of stamens \\
\hline
\end{tabular}




\section{Supplomint}

\begin{tabular}{|c|c|c|c|}
\hline \multicolumn{4}{|c|}{ Borage Family (Borraginàceae) } \\
\hline CUMMON NAME & $\begin{array}{l}\text { SCIENTIFIC } \\
\text { NANE }\end{array}$ & $\begin{array}{l}\text { INSECT } \\
\text { VISITORS }\end{array}$ & $\begin{array}{l}\text { METHOD OF PREVENT- } \\
\text { ING OR LIMTING SELF- } \\
\text { FERTLILATION, ETC: }\end{array}$ \\
\hline Viper's Bugless & $\begin{array}{l}\text { Èehium } \\
\text { vulgare }\end{array}$ & $\begin{array}{l}\text { Sixty-seven spe- } \\
\text { cies of insects }\end{array}$ & $\begin{array}{l}\text { Anthers mature before } \\
\text { stigma }\end{array}$ \\
\hline $\begin{array}{c}\text { Virginia or } \\
\text { Smooth Lumgwart, } \\
\text { or cowslip } \\
\end{array}$ & $\begin{array}{l}\text { Merténsia } \\
\text { Virgíniea }\end{array}$ & Many iusects & $\begin{array}{l}\text { Anthers widely separated } \\
\text { from stigma }\end{array}$ \\
\hline $\begin{array}{c}\text { True } \\
\text { Forget-me-not }\end{array}$ & $\begin{array}{l}\text { Myosotis } \\
\text { palústris }\end{array}$ & Flies or bees & $\begin{array}{l}\text { Authers and stigma so } \\
\text { arranged that they are } \\
\text { touched by opposite } \\
\text { sides of the tongue of } \\
\text { the visiting insect. Self- } \\
\text { fertilization possible }\end{array}$ \\
\hline $\begin{array}{l}\text { Common } \\
\text { IIoundstongue }\end{array}$ & $\begin{array}{l}\text { Cynoglóssum } \\
\text { offieinale }\end{array}$ & $\begin{array}{c}\text { Bees and } \\
\text { butterflies }\end{array}$ & Self-fertilization possible \\
\hline Beggrar's lice & $\begin{array}{c}\text { Cynoglóssmm } \\
\text { Morisoni }\end{array}$ & $\begin{array}{c}\text { Pollen-gathering } \\
\text { bees }\end{array}$ & See text \\
\hline \multicolumn{4}{|c|}{ Waterleaf Family (Hydrophyllàceae) } \\
\hline $\begin{array}{c}\text { Virginia } \\
\text { Waterleaf }\end{array}$ & $\begin{array}{c}\text { Il ydrophyllum } \\
\text { Virgmiemm }\end{array}$ & Bumblebees & $\begin{array}{c}\text { Anthers mature before } \\
\text { stigma }\end{array}$ \\
\hline \multicolumn{4}{|c|}{ Polemonium Family (Polemoniàceae) } \\
\hline $\begin{array}{l}\text { Sweet } \\
\text { William }\end{array}$ & $\begin{array}{c}\text { Phlox } \\
\text { maculàta }\end{array}$ & Butterflies ehiefly & $\begin{array}{l}\text { Anthers mature before } \\
\text { stigmas, but self-fertili- } \\
\text { zation is common }\end{array}$ \\
\hline $\begin{array}{l}\text { Towny } \\
\text { Phlox }\end{array}$ & $\begin{array}{l}\text { Phlox } \\
\text { pilosa }\end{array}$ & .6 & $\begin{array}{l}\text { Anthers mature before } \\
\text { stigmas, but self-fertili- } \\
\text { zation is common }\end{array}$ \\
\hline $\begin{array}{l}\text { Gromind or } \\
\text { Moss l'ink }\end{array}$ & $\begin{array}{l}\text { Phlox } \\
\text { subulata }\end{array}$ & 16 & $\begin{array}{l}\text { Anthers mature before } \\
\text { stigmas, but self-fertili- } \\
\text { zation is common }\end{array}$ \\
\hline \multicolumn{4}{|c|}{ Convolvulus Family (Convolvulàceae) } \\
\hline Morting-glory & $\begin{array}{c}\text { Ipomisa } \\
\text { purpùrea } \\
\end{array}$ & Bees & $\begin{array}{l}\text { Stigma matures before } \\
\text { anthers }\end{array}$ \\
\hline Wild I otato Vine & $\begin{array}{l}\text { Ipomoèa } \\
\text { pancluràta }\end{array}$ & Bumblebees & \\
\hline Field Bindweed & $\begin{array}{l}\text { Convólvus } \\
\text { arvéusis }\end{array}$ & $\begin{array}{c}\text { Bees, flies, and } \\
\text { beetles }\end{array}$ & $\begin{array}{l}\text { Stigmas protrude beyond } \\
\text { anthers. Self-fertilization } \\
\text { possible owing to droop- } \\
\text { ing position of flower }\end{array}$ \\
\hline Greài Bindweed & $\begin{array}{l}\text { Calystègia } \\
\text { sêpium }\end{array}$ & $\begin{array}{l}\text { Bees, moths, } \\
\text { and flies }\end{array}$ & Self-fertilization possible \\
\hline \multicolumn{4}{|c|}{ Nightshade Family (Solanàceae) } \\
\hline $\begin{array}{l}\text { Black or Common } \\
\text { Nightshade }\end{array}$ & $\begin{array}{l}\text { Solànum } \\
\text { nigrum }\end{array}$ & $\begin{array}{c}\text { Pollen-gathering } \\
\text { female bumble- } \\
\text { bees chiefly }\end{array}$ & \\
\hline Ground Cherry & $\begin{array}{l}\text { Plyýsalis } \\
\text { Penusylvánica }\end{array}$ & Bees & $\begin{array}{l}\text { Stigma matures before } \\
\text { anthers, also protrudes } \\
\text { beyond them }\end{array}$ \\
\hline $\begin{array}{l}\text { Conimonom } \\
\text { Thorn-alple }\end{array}$ & $\begin{array}{l}\text { Datiua } \\
\text { Stramonium }\end{array}$ & Sphinx moth & • \\
\hline
\end{tabular}




\begin{tabular}{|c|c|c|c|}
\hline \multicolumn{4}{|c|}{ Supplinint } \\
\hline \multicolumn{4}{|c|}{ Gentian Family (Gentianàceae) } \\
\hline COMMOX NAME & $\begin{array}{l}\text { SCIENTIFIC } \\
\text { NAME }\end{array}$ & $\begin{array}{l}\text { INSECT } \\
\text { VISITURS }\end{array}$ & $\begin{array}{l}\text { METHOD OF PIEVENT- } \\
\text { ING OR LIMTING SELF- } \\
\text { FERTILIZATION, ETC. }\end{array}$ \\
\hline Rosy C'entaury & $\begin{array}{l}\text { Sabbatia } \\
\text { atugulàris }\end{array}$ & Many insects & $\begin{array}{l}\text { Anthers mature before } \\
\text { stigna and open out- } \\
\text { ward }\end{array}$ \\
\hline Fringed Gentian & $\begin{array}{l}\text { Gentiàna } \\
\text { crinita }\end{array}$ & $\begin{array}{l}\text { Bees and } \\
\text { bumblebees }\end{array}$ & $\begin{array}{l}\text { Anthers mature before } \\
\text { stigna and open out- } \\
\text { ward }\end{array}$ \\
\hline $\begin{array}{l}\text { Closed or Blind } \\
\text { Gentian }\end{array}$ & $\begin{array}{l}\text { Gentiàna } \\
\text { Andréwsii }\end{array}$ & Bumblebees & $\begin{array}{l}\text { Anthers mature before } \\
\text { stigma and open out- } \\
\text { ward }\end{array}$ \\
\hline \multicolumn{4}{|c|}{ Dogbane Family (Apocynàceae) } \\
\hline $\begin{array}{l}\text { Spreadilig } \\
\text { Dogballe }\end{array}$ & $\begin{array}{l}\text { Apócymum } \\
\text { Androsanuifó- } \\
\text { limm }\end{array}$ & $\begin{array}{l}\text { Bees, flies, and } \\
\text { butterflies }\end{array}$ & $\begin{array}{l}\text { Pollen concealed in } V \text { - } \\
\text { shaped cavity well away } \\
\text { from stigma }\end{array}$ \\
\hline Indian Hemp & $\begin{array}{l}\text { Apócyumum } \\
\text { cannábinum }\end{array}$ & $\begin{array}{l}\text { Bees, flies, } \\
\text { and beetles }\end{array}$ & $\begin{array}{l}\text { Pollen secreted well away } \\
\text { from stigmatic cavity }\end{array}$ \\
\hline \multicolumn{4}{|c|}{ Milkweed Family (đAsclepiadàceae) } \\
\hline Butterfly-weed & $\begin{array}{l}\text { Asclèpias } \\
\text { tuberosa }\end{array}$ & Butterflies & $\begin{array}{l}\text { Pollen concealed in V- } \\
\text { shaped cavity well away } \\
\text { from stigma }\end{array}$ \\
\hline $\begin{array}{l}\text { Common } \\
\text { Milkweed }\end{array}$ & $\begin{array}{l}\text { A sclèpias } \\
\text { Cor'nùti }\end{array}$ & $\begin{array}{l}\text { Bees, flies, and } \\
\text { butterflies }\end{array}$ & $\begin{array}{l}\text { Pollen concealed in V- } \\
\text { shaped cavity well away } \\
\text { from stigma } \\
\end{array}$ \\
\hline \multicolumn{4}{|c|}{ Birthwort Family (Aristolochiàceae) } \\
\hline Wild Ginger & $\begin{array}{c}\text { Ásarum } \\
\text { Canadénse }\end{array}$ & Flies & \begin{tabular}{|l} 
Stigma matures before \\
anthers
\end{tabular} \\
\hline \multicolumn{4}{|c|}{ Pokeweed Family (Phytolaccàceae) } \\
\hline Pokeweed & $\begin{array}{c}\text { Phytolácea } \\
\text { decándla }\end{array}$ & Bees and flies & $\begin{array}{l}\text { Anthers grenerally mature } \\
\text { before stigma }\end{array}$ \\
\hline \multicolumn{4}{|c|}{ Buckwheat Family (Polygonàceae) } \\
\hline $\begin{array}{c}\text { Common } \\
\text { Persicària } \\
\end{array}$ & \begin{tabular}{|c|} 
Polygonum \\
Pennsylvánienm
\end{tabular} & Bees and flies & \\
\hline \multicolumn{4}{|c|}{ Lizard's-Tail Family (Saururàceae) } \\
\hline Lizard's-tail & $\begin{array}{c}\text { Saurùrus } \\
\text { céruumus }\end{array}$ & Flies & \\
\hline \multicolumn{4}{|c|}{ Laurel Family (Lauràceae) } \\
\hline Spicebush & $\begin{array}{l}\text { Líndera } \\
\text { Benzòin }\end{array}$ & Many insects & $\begin{array}{l}\text { Stigmatic flowers gener- } \\
\text { ally separate from stam- } \\
\text { inate ones }\end{array}$ \\
\hline \multicolumn{4}{|c|}{ Spurge Family (Euphorbiàceae) } \\
\hline Flowering Spurge & $\begin{array}{l}\text { Euphórbia } \\
\text { corollàta }\end{array}$ & Flies & $\begin{array}{l}\text { Staminate flowers sepa- } \\
\text { rate from stigmatic ones }\end{array}$ \\
\hline
\end{tabular}




\begin{tabular}{|c|c|c|c|}
\hline \multicolumn{4}{|c|}{ Supplement } \\
\hline \multicolumn{4}{|c|}{ Arum Family (Aràceae) } \\
\hline Commox Name & $\begin{array}{l}\text { S'IFNTIFIC } \\
\text { NAME }\end{array}$ & $\begin{array}{l}\text { INSECT } \\
\text { VISITORS }\end{array}$ & $\begin{array}{l}\text { METHOI OF PREVENT- } \\
\text { ING OR LIMITING SELF- } \\
\text { FERTILIZATION, ETC. }\end{array}$ \\
\hline $\begin{array}{c}\text { Jack-in-1he-Pulp,it } \\
\text { or } \\
\text { Indian Turnip }\end{array}$ & $\begin{array}{l}\text { Ariscèma } \\
\text { triphýllum }\end{array}$ & $\begin{array}{l}\text { Ginats and } \\
\text { other insects }\end{array}$ & $\begin{array}{l}\text { Stigmatie flowers gener- } \\
\text { ally separate from } \\
\text { staminate flowers. In } \\
\text { transition stage becom- } \\
\text { ing dioeeious } \\
\end{array}$ \\
\hline Water Arum & Cálla palústris & $\begin{array}{l}\text { Small insects, } \\
\text { midges, ete. }\end{array}$ & $\begin{array}{l}\text { Lower flowers staminate } \\
\text { and stigmatic. Upper } \\
\text { flowers staminate only } \\
\text { Stigma matures be fore } \\
\text { anthers }\end{array}$ \\
\hline $\begin{array}{l}\text { Skunk or Swamp } \\
\text { ('abbage }\end{array}$ & $\begin{array}{l}\text { Symploeárpus } \\
\text { fótidus }\end{array}$ & Flies & $\begin{array}{l}\text { Stigma matures before } \\
\text { anthe rs. Anthers } \\
\text { turned away from pis- } \\
\text { til. Odor unpleasant }\end{array}$ \\
\hline Golden Club & $\begin{array}{l}\text { Oróntium } \\
\text { ạuátieum }\end{array}$ & Flies and midges & $\begin{array}{l}\text { Cross-fertilized by insects } \\
\text { erawling over it }\end{array}$ \\
\hline \multicolumn{4}{|c|}{ Water-Plantain Family (Alismàceae) } \\
\hline Water Plantain & $\begin{array}{l}\text { Alísma } \\
\text { Plantago }\end{array}$ & Flies & $\begin{array}{l}\text { Stameus radiate away } \\
\text { from stigma }\end{array}$ \\
\hline $\begin{array}{l}\text { Broad-leaved } \\
\text { arrow-liead }\end{array}$ & $\begin{array}{l}\text { Saguttàriat } \\
\text { Vatriábilis }\end{array}$ & Bees and flies & $\begin{array}{l}\text { Stimmatie flowers sepa- } \\
\text { rate from staminate } \\
\text { ones }\end{array}$ \\
\hline \multicolumn{4}{|c|}{ Pickerel-Weed Family (Pontederiàceae) } \\
\hline P'ickerel-Weed & $\begin{array}{l}\text { Pontedèria } \\
\text { corrlata }\end{array}$ & Bees and flies & Trimorphic \\
\hline \multicolumn{4}{|c|}{ Orchis Family (Orchidàceae) } \\
\hline Showy Orchis & $\begin{array}{l}\text { Orchis } \\
\text { speetábilis }\end{array}$ & $\begin{array}{c}\text { Female } \\
\text { bumblebees }\end{array}$ & See text \\
\hline $\begin{array}{l}\text { The Purple- } \\
\text { Fringed Orehid } \\
\text { (smaller) }\end{array}$ & $\begin{array}{l}\text { llabenària } \\
\text { psyeodes }\end{array}$ & Butterflies & See text \\
\hline $\begin{array}{c}\text { The Ragged } \\
\text { orchid }\end{array}$ & $\begin{array}{l}\text { Habenària } \\
\text { lácera }\end{array}$ & Butterflies & See text \\
\hline $\begin{array}{c}\text { The Great Green } \\
\text { Orchis }\end{array}$ & $\begin{array}{l}\text { Habenàriat } \\
\text { orbienlàta }\end{array}$ & $\begin{array}{l}\text { Butterflies and } \\
\text { smatler motlos }\end{array}$ & See text \\
\hline $\begin{array}{c}\text { The Rattlesnake } \\
\text { Plantain } \\
\end{array}$ & Goodyèra & Bees & see text \\
\hline Arethusa & $\begin{array}{l}\text { Arethìsa } \\
\text { bulbòsa }\end{array}$ & $" 6$ & See text \\
\hline Pogonia & $\begin{array}{c}\text { Pogonia } \\
\text { ophioglossoìdes }\end{array}$ & 6 & see text \\
\hline Moccasin Flower & $\begin{array}{c}\text { Cypripèdium } \\
\text { aeaùle }\end{array}$ & $\begin{array}{c}\text { Bees and } \\
\text { bumblebees }\end{array}$ & See text \\
\hline \multicolumn{4}{|c|}{ Amaryllis Family (Amaryllidàceae) } \\
\hline $\begin{array}{c}\text { Yellow } \\
\text { Star Grass } \\
\end{array}$ & $\begin{array}{c}\text { Hypóxis } \\
\text { erécta }\end{array}$ & $\begin{array}{l}\text { Small bees } \\
\text { and flies }\end{array}$ & $\begin{array}{l}\text { Stamens radiate away } \\
\text { from stigma }\end{array}$ \\
\hline
\end{tabular}




\begin{tabular}{|c|c|c|c|}
\hline \multicolumn{4}{|c|}{ Supplement } \\
\hline \multicolumn{4}{|c|}{ Smilax Family (Smilàceae) } \\
\hline COMMION NAME & $\begin{array}{l}\text { SCIENTIFIC } \\
\text { NAIIE }\end{array}$ & $\begin{array}{l}\text { INSECT } \\
\text { IISITORS }\end{array}$ & $\begin{array}{l}\text { METHOD OF PREVENT- } \\
\text { ING OR LIMTING SELF- } \\
\text { FERTILIZATION, ETC. }\end{array}$ \\
\hline Carrion Flower & $\begin{array}{l}\text { Smilax } \\
\text { herbàcea }\end{array}$ & Green flesh flies & $\begin{array}{l}\text { Staminate flowers sepa- } \\
\text { rate from stigmatic ones }\end{array}$ \\
\hline \multicolumn{4}{|c|}{ Iris Family (Iradàceae) } \\
\hline Larger Blue Flag & Íris versícolor & $\begin{array}{l}\text { Bees and bumble- } \\
\text { bees }\end{array}$ & $\begin{array}{l}\text { Stigmatic surface covered } \\
\text { by flexible flap, which } \\
\text { insect opens as it with- } \\
\text { draws proboscis a nd } \\
\text { body from flower. An- } \\
\text { thers face away from } \\
\text { stigma }\end{array}$ \\
\hline \multicolumn{4}{|c|}{ Lily Family (Liliàceae) } \\
\hline $\begin{array}{l}\text { Great Flowered. } \\
\text { White Trillium }\end{array}$ & $\begin{array}{c}\text { Tríllimm } \\
\text { grandiflòrum } \\
\end{array}$ & Bees & $\begin{array}{c}\text { Authers mature before } \\
\text { stigma }\end{array}$ \\
\hline $\begin{array}{c}\text { Purple Trillium, } \\
\text { or Birthroot }\end{array}$ & $\begin{array}{l}\text { Tríllium } \\
\text { eréctum }\end{array}$ & $\begin{array}{l}\text { Green flesh flies } \\
\text { and beetles }\end{array}$ & $\begin{array}{l}\text { Evil smelling. Self-fertili- } \\
\text { zation possible. }\end{array}$ \\
\hline Nodding Trillium & $\begin{array}{l}\text { Tríllium } \\
\text { cérnumm }\end{array}$ & Bumblebees & $\begin{array}{c}\text { Anthers mature before } \\
\text { stigma }\end{array}$ \\
\hline $\begin{array}{c}\text { Indian } \\
\text { Cucumbel-root }\end{array}$ & $\begin{array}{c}\text { Medèola } \\
\text { Virgínica } \\
\end{array}$ & $\begin{array}{c}\text { No special visitor. } \\
\text { many insects }\end{array}$ & $\begin{array}{l}\text { Styles much longer tban } \\
\text { stamens }\end{array}$ \\
\hline $\begin{array}{c}\text { Blazing Star, } \\
\text { of } \\
\text { Devil's Bit } \\
\end{array}$ & $\begin{array}{l}\text { Chamælírium } \\
\text { lùteum }\end{array}$ & $\begin{array}{c}\text { Several insects, } \\
\text { no special visitor }\end{array}$ & $\begin{array}{l}\text { Stigmatic flowers on sep- } \\
\text { arate plants from the } \\
\text { staminate ones }\end{array}$ \\
\hline $\begin{array}{c}\text { American } \\
\text { White Hellebore }\end{array}$ & $\begin{array}{l}\text { Teràtrum } \\
\text { víride }\end{array}$ & Flies & $\begin{array}{l}\text { Anthers mature before } \\
\text { stigmas }\end{array}$ \\
\hline Bellwort & $\begin{array}{l}\text { Uvularia } \\
\text { perfoliàta }\end{array}$ & $\begin{array}{l}\text { Female bees } \\
\text { bumblebees }\end{array}$ & $\begin{array}{l}\text { Stigma protrudes beyond } \\
\text { anthers; strikes incom- } \\
\text { ing bee }\end{array}$ \\
\hline $\begin{array}{l}\text { Wild Spikenard, or } \\
\text { False Solomon's } \\
\text { Seal }\end{array}$ & $\begin{array}{l}\text { Smilacina } \\
\text { racemosa }\end{array}$ & Bees & $\begin{array}{l}\text { Stigma matures before } \\
\text { anthers }\end{array}$ \\
\hline $\begin{array}{c}\text { Smaller } \\
\text { Solomon's Seal }\end{array}$ & $\begin{array}{c}\text { Polygonàtum } \\
\text { bifiòrum }\end{array}$ & Bees & $\begin{array}{l}\text { Self-fertilization quite fre- } \\
\text { quent }\end{array}$ \\
\hline $\begin{array}{l}\text { Wild Orange-Red } \\
\text { Lily }\end{array}$ & $\begin{array}{c}\text { Lílium } \\
\text { Philadélphicum }\end{array}$ & $\begin{array}{c}\text { Pollen-gathering } \\
\text { bees }\end{array}$ & \\
\hline Canada Lily & $\begin{array}{c}\text { Lílium } \\
\text { Canadénse }\end{array}$ & $\begin{array}{l}\text { Pollen-gathering } \\
\text { bees, butterflies }\end{array}$ & $\begin{array}{l}\text { Drooping position of } \\
\text { flower re nders self- } \\
\text { fertilization difficult }\end{array}$ \\
\hline Turk's Cap & $\begin{array}{l}\text { Lílium } \\
\text { supérbum }\end{array}$ & $\begin{array}{l}\text { Pollen-gathering } \\
\text { bees, butterflies }\end{array}$ & $\begin{array}{l}\text { Drooping position of } \\
\text { flower renders self- } \\
\text { fertilization difficult }\end{array}$ \\
\hline $\begin{array}{l}\text { Yellow Adder's } \\
\text { Tongue, or Dog- } \\
\text { tooth Violet }\end{array}$ & $\begin{array}{l}\text { Erythrònium } \\
\text { Americànum }\end{array}$ & $\begin{array}{l}\text { Small bees, butter- } \\
\text { flies, and flies }\end{array}$ & Self-fertilization common \\
\hline Wild Hyacinth & Scilla Fràseri & $\begin{array}{l}\text { Bees, flies, and } \\
\text { butterfies }\end{array}$ & \\
\hline
\end{tabular}


Spiderwort Family (Commelynàceae)

\begin{tabular}{|c|c|c|c|}
\hline COMMON NAME & $\begin{array}{c}\text { SCIENTIFIC } \\
\text { NAME }\end{array}$ & $\begin{array}{l}\text { INSECT } \\
\text { VISITORS }\end{array}$ & $\begin{array}{l}\text { METHOD OF PREVENT- } \\
\text { ING OR LIMITING SELF- } \\
\text { FERTILIZATION, ETC. }\end{array}$ \\
\hline $\begin{array}{l}\text { Virginia or } \\
\text { Common Day } \\
\text { Flower }\end{array}$ & $\begin{array}{l}\text { Commelyna } \\
\text { lirgínica }\end{array}$ & $\begin{array}{c}\text { Pollen-collecting } \\
\text { bees }\end{array}$ & \\
\hline Spiclerwort & $\begin{array}{l}\text { Tradescántia } \\
\text { Virginica }\end{array}$ & $\begin{array}{c}\text { Pollen-collecting } \\
\text { bees }\end{array}$ & $\begin{array}{l}\text { Stigma separated from } \\
\text { anthers, extending so } \\
\text { far beyond them that } \\
\text { self-fertilization is in- } \\
\text { probable }\end{array}$ \\
\hline
\end{tabular}

\section{roormin

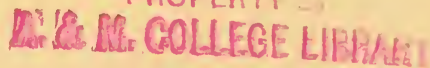




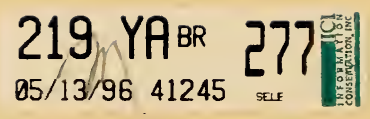





